IZA DP No. 7043

Regional Unemployment, Gender and Time Allocation of the Unemployed

J. Ignacio Gimenez-Nadal Jose Alberto Molina

November 2012 


\title{
Regional Unemployment, Gender and Time Allocation of the Unemployed
}

\author{
J. Ignacio Gimenez-Nadal \\ University of Zaragoza \\ Jose Alberto Molina \\ University of Zaragoza and IZA
}

Discussion Paper No. 7043

November 2012

\author{
IZA \\ P.O. Box 7240 \\ 53072 Bonn \\ Germany \\ Phone: +49-228-3894-0 \\ Fax: +49-228-3894-180 \\ E-mail: iza@iza.org
}

Any opinions expressed here are those of the author(s) and not those of IZA. Research published in this series may include views on policy, but the institute itself takes no institutional policy positions. The IZA research network is committed to the IZA Guiding Principles of Research Integrity.

The Institute for the Study of Labor (IZA) in Bonn is a local and virtual international research center and a place of communication between science, politics and business. IZA is an independent nonprofit organization supported by Deutsche Post Foundation. The center is associated with the University of Bonn and offers a stimulating research environment through its international network, workshops and conferences, data service, project support, research visits and doctoral program. IZA engages in (i) original and internationally competitive research in all fields of labor economics, (ii) development of policy concepts, and (iii) dissemination of research results and concepts to the interested public.

IZA Discussion Papers often represent preliminary work and are circulated to encourage discussion. Citation of such a paper should account for its provisional character. A revised version may be available directly from the author. 
IZA Discussion Paper No. 7043

November 2012

\section{ABSTRACT \\ Regional Unemployment, Gender and Time Allocation of the Unemployed ${ }^{*}$}

This paper analyzes the relationship between time allocation decisions of the unemployed, gender, and regional unemployment rates. Using the Spanish Time Use Survey 2002-2003 and 2009-2010, we find that higher regional unemployment rates are associated with increases in the time devoted to study by men, and to household production by women, and with decreases in the time devoted to personal care by men and leisure by women. We also find evidence favoring consumption smoothing as the channel through which others' unemployment affects time allocation decisions of the unemployed. As higher regional unemployment rates imply a lower availability of jobs for the unemployed, it decreases the expectations individuals have of finding a job, and thus households may try to increase their time spent on household production to reduce the market expenditures needed to maintain their consumption. We interpret our results as evidence that others' unemployment has several effects that need to be considered in the analysis of the wellbeing of the unemployed during business cycles.

JEL Classification: D13, J16, J22

Keywords: unemployment, time use, regional unemployment rates, gender

Corresponding author:

J. Ignacio Gimenez-Nadal

Department of Economic Analysis

Faculty of Economics

C/ Gran Via 2, 3rd floor

50005 Zaragoza

Spain

E-mail: ngimenez@unizar.es

\footnotetext{
* We are grateful for helpful comments from Almudena Sevilla, and participants in the conferences of the Spanish Association in Applied Economics (2009), European Society for Population Economics (2009), the Spanish Association of Labour Economics (2009), the European Economic Association (2009), the European Association for Labour Economists (2009), the International Association for Time Use Research (2009), and the Spanish Association of Economic Analysis (2009). Financial support provided by the Spanish Ministry of Economy and Competitiveness (Project ECO2012-34828) is also acknowledged. Remaining errors are our sole responsibility.
} 


\section{INTRODUCTION}

This paper examines whether others' unemployment has any effect on the time allocation decisions of the unemployed, and the gender differences associated with these effects. Aguiar, Hurst and Karabarbournis (2012) argue that the home production sector is a viable margin of substitution during business cycles, allowing some degree of substitutability between market consumption and leisure. They find that roughly $30 \%$ of the foregone market work hours due to the business cycle are reallocated to non-market production, suggesting small falls in consumption (and implicitly wellbeing) despite the decrease in expenditure. However this reallocation of work to home production may have implications for wellbeing since the way individuals use their time is also directly related to their well-being (see Kahneman et al. (2004), who argue that individual time use produces a "continuous hedonic flow of pleasure or pain” during the day). To the extent that regional unemployment rates affect how individuals use their time, our paper sheds light on the welfare implications of the business cycle for individuals.

Previous research on the macroeconomics of happiness has shown that individual well-being is related to aggregate macroeconomic variables such as the unemployment rate, inflation, and interest rates. Di Tella, MacCulloch and Oswald (2001) show that unemployment rates affect well-being negatively, since inflation and unemployment are part of a social welfare function. The theoretical argument behind the reasons why unemployment rates affect individual well-being lies in an individual's own perception of job insecurity: greater unemployment reduces the chances of finding work for a given unemployed individual. In contrast, Clark (2003) finds that regional unemployment reduces the well-being of the employed, but that the unemployed report higher levels of well-being in regions with higher unemployment. The reason for this finding lies in the notion that the unemployed may benefit from a "social-norm effect": as more people become unemployed, one's own unemployment represents a smaller deviation from the social norm, and thus the effect of unemployment on individual well-being is lower.

We contribute to the above literature by testing these two theories to observe the channels through which others' unemployment affects the time allocation decisions of the unemployed. If according to Di Tella, MacCulloch and Oswald (2001) higher unemployment rates imply that unemployed individuals may be more discouraged, we would then expect unemployed individuals to devote more time to home production activities to compensate for the loss in expenditure power (and thus smooth 
consumption), and more time to study as a way of increasing their chances of finding a job. However, if regional unemployment rates affect the time allocation decisions of the unemployed through a "social-norm effect", we expect to find a positive relationship between regional unemployment rates and leisure of the unemployed, as there are more individuals to spend time in leisure activities (Jenkins and Osberg, 2005).

We use a sample of unemployed individuals from the Spanish Time Use Survey (STUS) 2002-2003 and 2009-2010 to analyze the relationship between regional unemployment rates and time allocation decisions of the unemployed. Our identification strategy for the effect of other's unemployment on the uses of time of the unemployed comes from the time and cross-region variations of the data. We have two cross-sections and we exploit the quarterly regional unemployment rates that provide 8 observations for each of the 17 regions of Spain. The STUS provides us with information on individual time use, based on diary questionnaires in which individuals report their activities throughout the 24 hours of the day. The advantage of time-use surveys over stylized-questions, such as those included in the European Community Household Panel, the British Household Panel Survey or the German Socioeconomic Panel, where respondents are asked how much time they have spent, for example, in the previous week, or normally spend each week, on market work or housework, is that diary-based estimates of time use are more reliable and accurate than estimates derived from direct questions (Juster and Stafford, 1985; Robinson and Godbey, 1997; Bianchi et al., 2000; Bonke, 2005; Yee-Kan, 2008).

We regress the time devoted to study, job search, household production, personal care and leisure, on unemployment rates of the different Spanish regions (Comunidades Autonomas). We carry out the analysis separately by gender because it is wellestablished in the literature that time use patterns of men and women are different, and while women spend more time in household production and childcare, men devote more time to market work and leisure (Kalenkoski et al., 2005; 2009; Aguiar and Hurst, 2007; Guryan et al., 2008; Conelly and Kimmel, 2009; Gimenez-Nadal and Sevilla-Sanz, 2012). Thus, the previously hypothesized effects of regional unemployment on the time allocation decisions of the unemployed may depend on gender. This is especially the case in Mediterranean countries like Spain, with entrenched traditional gender norms regarding the household distribution of household labor (Sevilla-Sanz, Gimenez-Nadal and Fernandez, 2010; Gimenez-Nadal, Molina and Sevilla, 2012) and with an inflexible 
labor market where part-time employment is very rare (Fernández-Kranz and Rodríguez-Planas, 2011).

We find that higher unemployment rates in a region are associated with increases in the time devoted to study by men, and to household production by women, with associated decreases in the time devoted to personal care by men and leisure by women. We find no effects on the time devoted to job search. Our results are consistent with alternative specifications where we include heterogeneous effects based on urban residence, civic status, and the working status of the partner. Specifically, a onepercentage-point increase in the unemployment rate of the region is associated with increases of 0.05 hours per day of study for men and of household production for women, while the same increase is associated with decreases of 0.07 and 0.10 hours per day of personal care for men and of leisure for women.

Hence, comparing men living in La Rioja and Canarias, the two Spanish regions with the respective lowest and highest male unemployment rates during the analyzed years, unemployed men in Canarias (30.02\% male unemployment) devote 1.52 more hours and 1.88 fewer hours per day to study and personal care, respectively, compared to unemployed men in La Rioja (2.81\% male unemployment). Comparing women living in Navarra and Andalucía, the two Spanish regions with the respective lowest and highest female unemployment rates during the analyzed years, unemployed women in Andalucía (30.67\% female unemployment) devote 1.29 more hours and 2.39 fewer hours per day to household production and leisure, respectively, compared to unemployed women in Navarra (7.63\% female unemployment).

The fact that we do find no any association between regional unemployment rates on leisure for unemployed men, and that the association for women's leisure time is negative, indicates that synchronization of activities is not the main channel through which regional unemployment rates affect the time allocation decisions of individuals, and thus the "social-norm effect" is not at the root of the observed effect of regional unemployment rates and time allocation decisions of the unemployed. We find that unemployed men as part of a couple devote more time to household production, while unemployed women as part of a couple devote more time to household production compared, to their single counterparts. We interpret this result as indicating that higher regional unemployment rates decrease the expectations individuals have of finding a job. In this situation, households try to increase their time spent on household 
production, allowing them to reduce the market expenditures needed to maintain their consumption

The rest of the paper is organized as follows. Section 2 presents the data and variables. Section 3 describes the empirical strategy. Section 4 presents our main results, and Section 5 sets out our main conclusions.

\section{DATA: THE SPANISH TIME USE SURVEY 2002-2003 AND 2009-2010}

The data used for the empirical analysis come from the Multinational Time Use Study (MTUS) version of the 2002-03 Spanish Time Use Survey (STUS), and the 2009-2010 STUS. ${ }^{1}$ The MTUS is an ex-post harmonized cross-time, cross-national, comparative time use database, coordinated by the Centre for Time Use Research at the University of Oxford. It is constructed from national randomly-sampled time-diary studies, with a common series of background variables, and total time spent in 69 activities (Gershuny, 2009). The STUS consists of representative samples of Spanish households and contains information on daily activities, gathered by means of the completion of a personal diary and household and individual questionnaires. The sample is evenly distributed over the year and the week, in order to accurately represent time-use patterns for all days of the year. The survey includes an activities diary, which all members of the household aged 10 and older complete on a selected day. The diary time frame is twenty-four consecutive hours (from 6:00 a.m. until 6:00 a.m. the following day) and is divided into ten-minute intervals. In each of the intervals, the respondent records a main activity. $^{2}$

The use of the STUS places certain limitations on our analysis, compared to other time use studies such as those used by Burda and Hamermesh (2010) and Aguiar, Hurst, and Karabarbournis (2012). For instance, Burda and Hamermesh (2010) use data from the American Time Use Survey (ATUS) for the period 2003-2006 to analyze how longterm and cyclical unemployment rates affect the time devoted to different categories by individuals. Aguiar, Hurst, and Karabarbournis (2012) use the ATUS for the period 2003-2010 for a comprehensive analysis of time use prior to and during the recent U.S. recession, allowing the authors to document how the allocation of time evolves over the

\footnotetext{
${ }^{1}$ See Appendix A for a description of the sample used in the analysis.

2 A full description of activities can be found in the Spanish Statistical Office, http://www.ine.es/prodyser/micro_emptiem.htm.
} 
business cycle. However, the fact that the two STUS surveys are cross-section datasets composed of time use diaries of individuals, covering one year, means that we do not have sufficient time variation to identify how the allocation of time evolves over the business cycle, or to differentiate between the types of unemployment rate. Thus, we have regional and time (quarters) variations that only allow us to identify how differences in unemployment rates between Spanish regions affect the time allocation decisions of unemployed individuals, but not to identify the effects of the business cycle on such allocation decisions. Additionally, there may be other factors at the regional level that could drive the results, and we would be able to avoid such effects if we had sufficient time variation in the data. Instead, we use other regional variables to net out the effect of regional unemployment rates from the effects of other regional factors.

We define the following time use activities, measured in hours per day: Study, Job search, Household production, Personal care and Leisure. ${ }^{3}$ Study refers to time spent in education, and Job Search refers to the time spent in job seeking. Household production refers to activities in which individuals engage at home, using their own time and some purchased goods, and have the common characteristic that they could pay another individual to perform them, while not themselves being paid (Burda, Hamermesh and Weil, 2008). Personal Care refers to things that individuals cannot pay others to do, but must do for themselves, at least to some extent. Examples of these activities include sleeping and eating, activities that are necessary for survival. Finally, Leisure includes all activities that individuals cannot pay others to do, and that do not really have to be done at all.

We use unemployment rates for each Spanish region (Autonomous Community) provided by the Spanish Statistical Office (Instituto Nacional de Estadistica, 2012). However, given that unemployment rates are so different by gender during the relevant period, we consider unemployment rates for men and women separately. Thus, for each individual (male or female), we link the corresponding regional unemployment rate by gender, using the year of the survey (2002, 2003, 2009 or 2010), the region of residence (Aragon, Madrid, Catalonia...), and the quarter of the survey. Thus, for a woman respondent living in Catalonia and answering the survey in May of 2003, we use the

\footnotetext{
${ }^{3}$ All these activities are measured as primary activities. Väisänen (2006) shows that the amount of time reported as secondary activity in the STUS 2002-03 is 82 minutes (out of 1440 minutes per day), the lowest among the UK, Finland, France, Germany, Italy, Norway and Sweden, which makes the inclusion of secondary activities in the analysis not relevant. Some of the definitions for our time use categories are taken from Burda, Hamermesh and Weil (2008). Definitions of the different time use activities can be found in Table B1 of Appendix B.
} 
regional unemployment of Catalonia in the second quarter of the year 2003 for women. Table A2 in the Appendix shows unemployment rates for the different regions and quarters. There are significant differences in unemployment rates between men and women, and across regions. While unemployment rates are around 25\% for women in Extremadura, unemployment rates for men are around $12 \%$ in the same region. Similarly, while unemployment rates for men are around 5\% in Madrid, unemployment rates for men in Andalucia are around 14\%.

\section{Summary Statistics}

Column (1) in Table 1 shows the time devoted to the different time use categories measured in hours per day, by gender. We observe that both unemployed men and women devote most of their time to personal care (11.89 and 11.43 hours per day for men and women, respectively) and leisure (8.36 and 5.77 hours per day for men and women, respectively). However, we find gender differences in the other uses of time, and while unemployed men devote more time to leisure (8.36 and 5.77 hours per day for men and women, respectively) and job search ( 0.45 and 0.10 hours per day for men and women, respectively), unemployed women devote more time to household production than do men (2.63 and 5.98 hours per day, respectively). Such differences may indicate that the alternative uses of time when individuals are unemployed vary by gender, which motivates our analysis by gender in the following Sections. Column (2) shows the percentage of individuals participating in the reference time use category during the day of the interview. We observe that, while some time use categories have a low participation rate by individuals in the sample (e.g., study and job search), household production and leisure have a higher proportion, with all the individuals devoting some time to personal care. Consistent with the previously reported gender differences in the time devoted to the different activities, we find differences in the percentage of individuals participating in these activities, and while unemployed men have a higher participation in job search, unemployed women have a higher participation in household production.

We analyze the raw relationship between unemployment rates and the time devoted to the various activities by plotting the time devoted to the reference activity at the region level and the overall unemployment rate of the region, by gender. For instance, for the time devoted to study by men, we compute the overall time (hours per day) 
devoted by unemployed men in each region and each quarter to this activity, and we plot this overall time with the unemployment rate of the region. Figures 1 and 2 show the plots for men and women, where we have added a regression line. For men, we observe a negative relationship between regional unemployment rates and the time devoted to study, while we find positive relationships between regional unemployment rates and the time devoted to both household production and personal care. In particular, we find that the correlation between regional unemployment rates and the time devoted to study, household production, and personal care, by men, is $-0.20,0.10$ and 0.12 , respectively. In the case of women, we observe a negative relationship between regional unemployment rates and the time devoted to leisure, while we find positive relationships between regional unemployment rates and the time devoted to both household production and personal care. In particular, we find that the correlation between regional unemployment rates and the time devoted to leisure, household production, and personal care by men is $-0.15,0.12$ and 0.07 , respectively. For the other activities, we consider that the correlation is far from significant.

Thus, the raw analysis of the time devoted to the different uses of time and regional unemployment rates shows gender differences, and while we find a negative correlation between regional unemployment rates and the time devoted to study for men, we find a negative correlation between regional unemployment rates and the time devoted to leisure for women. Thus, there may be gender differences in the effect of regional unemployment rates on the time allocation decisions of individuals, but in this analysis we do not control for other factors that may affect these decisions, such as the presence of children and the educational level of individuals. Thus, in the following Section we analyze such relationships, controlling for other factors.

\section{EMPIRICAL STRATEGY}

We estimate OLS regressions on the time devoted to the different time use categories, by gender. However, since we observe a high proportion of "zeros" in certain time use categories, such as study and job search (see Column 2 in Table 1), there can be some controversy regarding the selection of alternative models, such as that of Tobin (1958). According to Frazis and Stewart (2012), OLS models are preferred in the analysis of time allocation decisions, since estimation techniques for limited dependent variables that assume a non-linear functional form, such as the Tobit model, will be inconsistent 
if we want to estimate means of long-run time use from a sample of daily observations. Gershuny (2012) argues that estimations derived from single-day diaries have the problem of too many zeros, but traditional diary studies can still produce accurate estimates of mean times in activities for samples and subgroups. Under this framework, Foster and Kalenkoski (2013) compare the use of tobit and OLS models in the analysis of the time devoted to childcare activities, and find that the qualitative conclusions are similar for the two estimation methods. Thus, we rely on OLS models, although we have alternatively estimated tobit models, and our qualitative conclusions are the same (results are shown in appendix Tables C1 and C2 for men and women).

We estimate the following equation:

$$
\mathrm{T}_{\mathrm{ijt}} \boldsymbol{\theta}^{+}+\beta \text { Reg_Unemp } \underset{\mathrm{jt}}{+} \gamma \mathrm{X} \underset{\mathrm{ijt}}{\mathrm{j} t} \text { Day } \underset{\mathrm{ijt}}{+} \delta \mathrm{Z}_{\mathrm{jt}}^{+} \varepsilon_{\mathrm{ijt}}
$$

where $T_{i j t}$ represents the time devoted to the reference activity by individual "i" in region "j" at time "t", and Reg_Unemp $p_{j t}$ is the variable indicating the regional unemployment rate in region " $\mathrm{j}$ ” at time " $\mathrm{t}$ ". The vector $X_{i}$ includes standard individual and household characteristics (see, Bianchi et al., 2000; Kalenkoski, Ribar and Stratton, 2005; Krueger, 2007; Connelly and Kimmel, 2009, Sevilla-Sanz, Gimenez-Nadal and Fernandez, 2010; Gimenez-Nadal, Marcen and Ortega-Lapiedra, 2010, Gimenez-Nadal and Ortega-Lapiedra, 2010; Gimenez-Nadal and Sevilla-Sanz, 2012) such as age and its square, university education, secondary education, health status, number of children $<18$, paid housekeeper, and household net monthly income. ${ }^{4}$ We also include a vector of dummy variables to scale the day of the week (Ref.: Friday), and we cluster observations by region of residence to allow for differences in the variance/standard errors due to arbitrary intra-group correlation, as in Burda and Hamermesh (2010).

One of the potential identification problems of the association between unemployment rates and the time allocation decisions of the unemployed is that any permanent difference across regions may lead to a biased coefficient on unemployment rates, if these differences are correlated with the time allocation decisions of the unemployed, as well as with unemployment rates. We provide an identification strategy

\footnotetext{
${ }^{4}$ The information for net household income in the STUS 2009-10 is very limited, since many households do not report such information. Thus, we have computed the household income for those households not providing information on income. In doing so, we have estimated household income based on age of respondent and its square, respondent's education, the number of children under 18, the presence of a paid housekeeper, whether the household lives, or not, in an urban area, and whether the respondent is part of a couple, or not. We have then estimated the value of household income. In this process, we have bootstrapped standard errors to obtain consistent results. See Table A3 in Appendix A for results of regressions on household income.
} 
that comes from the time and cross-region variations of the data, given that we use quarterly regional unemployment rates that provide 8 observations for each region. We also control for other regional variables $\left(Z_{j t}\right)$ to net out the effect of regional unemployment rates from the effects of other regional factors. ${ }^{5}$

We have included a first set of variables: Consumer Price Index, Activity Rates (by gender), Industrial Production Index, and the Industrial Price Index, to control for differences in business cycles between regions. All these indicators may serve to control for the fact that, during recessions, individuals may be more discouraged in areas where unemployment rates are higher and have reduced economic expectations compared to areas with lower unemployment rates and heightened economic expectations, which may influence their time allocation decisions. Furthermore, we have included regional variables to control for differences in the wealth of the Spanish regions: Gross Domestic Product and Income per capita. For instance, in wealthier regions, the unemployed may have better economic support from their families and the regional government, compared to poorer regions, which may influence time allocation decisions of individuals, such as job search or leisure (better support may be translated into less time devoted to job search and more time in leisure, for instance).

We also include variables to control for differences across regions in the health status of individuals (percentage of individuals in each region reporting having good, poor, and very poor health, as opposed to very good health), given that in regions where individuals have poorer health, unemployment rates may be higher. We include the percentage of people in each region who report having very poor health (\% people in region with very poor health), poor health (\% people in region with poor health), and good health (\% people in region with good health). ${ }^{6}$ We additionally include divorce rates at the region level (Divorce Rates), since in regions with higher rates of divorce, the probability that unemployed individuals are not in couples is higher, which would indicate that the unemployed do not have the support of their partners, influencing their time allocation decisions.

\footnotetext{
${ }^{5}$ Although we present here some examples as to why controlling for such variables is important, we do not pretend to offer an exhaustive explanation of the channels through which these variables affect the time allocation decisions of the unemployed. All these variables are obtained from the Spanish Statistical Office (INE, Instituto Nacional de Estadistica). See Table A4 in Appendix A for mean values of the variables for each region.

${ }^{6}$ Information on health status comes from the Survey on Health and Sexual Habits. Despite that this survey was developed in the year 2003, the last year it was carried out was 2006 and thus we have no exact information on the health status of individuals in the regions for the year 2009-2010. However, we have used the information for the survey carried out in 2006, as if it was the real information for the year 2009-2010.
} 
Finally, we have included a variable to measure the share of public jobs relative to the number of private jobs in the region (Share of public jobs relative to private). Differences in such shares may be important in the behaviour of the unemployed, given that in those regions with high proportions of public jobs it could be that the unemployed have the expectation that there will be new job offers in the public sector, and thus they will try to increase their probability of getting a job in the public sector by devoting more time to study, and less time to job search. On the contrary, in those regions with low proportions of public jobs, it could be that the unemployed have no expectations of working in the public sector, and thus they would devote less time to study and more to job search.

\section{RESULTS}

Tables 2 and 3 shows the results of estimating equation (1) on the time devoted to study, job search, household production, personal care, and leisure, for both men and women. Considering the coefficients of regional unemployment rates on the time devoted to the different activities, we observe positive associations for the time devoted to study by men and household production by women, and negative associations for the time devoted to personal care by men and leisure by women, with these associations being statistically significant at standard levels. A one-percentage-point increase in the unemployment rate of the region is associated with increases of 0.05 hours per day of study and household production for men and women, respectively, which translates into a $3 \%$ and $1.5 \%$ increase of a standard deviation in the time devoted to study and household production, respectively. We also observe that a one-percentage-point increase in the unemployment rate of the region is associated with decreases of 0.07 and 0.10 hours per day of personal care and leisure for men and women, respectively, which translates into a $3 \%$ and $3.5 \%$ decrease of a standard deviation in the time devoted to study and household production, respectively.

We obtain significant correlations between others' unemployment and the time allocation decisions of the unemployed, although there are gender differences associated with these correlations. While there seems to be a substitution between the time devoted to study and personal care by men with higher unemployment rates of the region of residence, these higher unemployment rates seem to be associated with a substitution between the time devoted to household production and leisure by women. To the extent 
that individual time use is related to day-to-day well-being, such differences may indicate that the consequences of other's unemployment on the well-being of the unemployed vary by gender.

Other factors associated with changes in the time allocation decisions of unemployed men are the level of education, age, and the presence of children, while for unemployed women the level of education, age, the presence of children, and health status are factors that may affect their time allocation decisions. For men, we observe an inverse u-shaped effect of age on the time devoted to household production, university education is positively related to study and household production and negatively related to personal care and leisure, and each additional child in the household is associated with increases in the time devoted to household production and decreases in the time devoted to study, personal care, and leisure. For women, we observe an inverse u-shaped relationship for age on the time devoted to household production, and u-shaped relationships with the time devoted to study, personal care, and leisure, and university education is positively related to study and negatively related to household production. Also, each additional child in the household is associated (for women) with increases in the time devoted to household production and decreases in the time devoted to study, job search, personal care, and leisure, while poor health is associated with increases in the time devoted to study and decreases in the time devoted to job search and personal care.

\subsection{Regional unemployment rates and urban/rural residence}

Living in urban areas may have different effects for the unemployed, compared to those living in rural areas. Since economic activity is normally concentrated in urban areas (Black and Henderson, 1999; Desmet and Fafchamps, 2005; Ottaviano and Pinelli, 2006; Partridge et al., 2008a, 2008b, 2010), it may be that despite high regional unemployment rates, the unemployed living in urban areas have more opportunities to find a job than those in rural areas. In this situation, the unemployed in urban areas may devote more time to seeking employment and less time to household production and leisure, since they may want to concentrate on finding a job. Additionally, they may devote less time to seeking employment because they know they will find a job in the near term, and as a result they could extend their period of receiving unemployment benefits. It may also be the case that the unemployed in urban areas have more competition for employment, and this may have a discouraging effect. Moreover, urban 
areas may offer a much greater range of things to do in leisure time, compared to rural areas, reflecting differences in the uses of time of the unemployed. Finally, unemployment rates may be higher in the more agricultural regions of Spain, where more traditional ways of life increase household production. Thus, how people living in rural or urban areas adapt to unemployment is not known a priori, and further research is needed to see if the effects of regional unemployment rates vary depending on the urban/rural residence.

We next estimate equation (1), including a dummy variable to control for the urban/rural residence of the respondent, interacting the urban/rural dummy with the variable measuring regional unemployment rates, to analyze whether the effects of regional unemployment rates are different according to the urban/rural residence of the respondent. We create a dummy variable to indicate whether the respondent lives in an urban area (1) or not (0), using the aggregation level of the Multinational Time Use Study version of the STUS (the study considers that the individual lives in an urban area if the city has 50,000 or more inhabitants, and in a rural area if there are less than 50,000 inhabitants). According to this aggregation, $65.04 \%$ of the individuals included in the survey live in urban areas.

Panels A and B in Table 4 show the results of estimating equation (1) including urban area of residence and its interaction with the regional unemployment rate for men and women (see Tables C3 and C4 for results for the rest of variables). For unemployed men, we observe that while the association between regional unemployment rates and the time devoted to study does not depend on the urban/rural residence of men, men living in urban areas experience a larger effect on the time devoted to personal care. In the case of unemployed women, the relationship between regional unemployment rates and the time devoted to household production and leisure seems to be more significant in urban areas, while we find a specific effect on the time devoted to study in urban areas. Hence, we find that the relationships between regional unemployment rates and the time devoted by the unemployed to household production, personal care, and leisure are stronger in urban areas. The time devoted to study by unemployed men does not vary by urban or rural residence, but there is a specific effect for unemployed women living in urban areas.

In particular, for unemployed men we observe that the relationship between higher regional unemployment rates and more time devoted to study does not depend on the 
urban/rural residence of respondents, as the interaction between regional unemployment rates and the dummy variable for urban residence is not statistically significant. However, the negative relationship between regional unemployment rates and the time devoted to personal care is more significant in urban areas, as shown by the statistically significant coefficient of regional unemployment rates interacted with urban residence. Hence, while a one-percentage-increase in the unemployment rate of the region is associated with a decrease of 0.05 hours per day devoted to personal care in rural areas, the same increase in regional unemployment rates is associated with a decrease of 0.07 hours per day devoted to the same activity in urban areas.

In the case of unemployed women, we observe that the relationship between regional unemployment rates and the time devoted to both household production and leisure depends on the urban/rural residence of respondents, as the interaction between regional unemployment rates and the dummy variable for urban residence is statistically significant at standard levels. Hence, while a one-percentage-increase in the unemployment rate of the region is associated with 0.04 more hours and 0.08 fewer hours per day in the time devoted to household production and leisure in rural areas, respectively, the same increase in regional unemployment rates is associated with 0.07 more hours and 0.11 fewer hours per day devoted to household production and leisure in urban areas, respectively. Additionally, we find a specific relationship between regional unemployment rates and the time devoted to study for unemployed women living in urban areas, as a one-percentage-point increase in the unemployment rate of the region is associated with an increase of 0.02 hours per day of the time devoted to study.

\subsection{Regional unemployment rates and the presence of partners}

We now analyze whether the relationship between regional unemployment rates and the time allocation decisions of the unemployed depend on their marital status. The existing literature has shown that time allocation decisions may differ, depending on the civic status of individuals. For instance, Kalenkoski, Ribar and Stratton (2005) find that single parents in the UK devote more time to childcare activities compared to their married counterparts. Connelly and Kimmel (2007) find that, if there is a married spouse present, mothers in the US devote more time to home production (and employment) and less time to leisure. Gimenez-Nadal and Sevilla (2010) show that, at 
the European level, married women with children are those with lower levels of leisure time. One of the reasons why the time allocation decisions of individuals in a couple are different from those of individuals not in a couple may be synchronization of activities, since prior research has shown that individual time use choices may be contingent on the time use choices of others (Hamermesh 2000; Halberg 2003; Jenkins and Osberg 2005). ${ }^{7}$

Thus, the civic status of the unemployed may influence how others' unemployment affects the time allocation decisions of the unemployed, given that it affects the availability of other individuals to synchronize activities. We estimate equation (1) including a dummy variable to control for whether or not the respondent is part of a couple, interacting this dummy variable with the variable measuring regional unemployment rates, to analyze whether the effects of regional unemployment rates differ with the civic status of the respondent. We create a dummy variable to indicate whether the respondent is part of a couple (1) or not (0). Panels A and B in Table 5 show the results of estimating equation (1) including the civic status and its interaction with the regional unemployment rate for men and women (see Tables C5 and C6 for results for the rest of variables). For unemployed men, we observe that the relationship between regional unemployment rates and the time devoted to study is positive, independently of whether they are part of a couple or not, but the negative relationship for the time devoted to personal care is more significant for individuals living in couple, as shown by the negative and statistically significant coefficient on the interaction term. Additionally, we find specific effects for unemployed men living in couple on the time devoted to household production and leisure, as shown by the positive and negative statistically significant coefficients of the interaction term on the time devoted to household production and leisure, respectively.

A one-percentage-point increase in the unemployment rate of the region is associated with an increase of 0.05 hours per day devoted to study by unemployed men, with no difference in the effect between men living, or not, as part of a couple. Considering the time devoted to personal care, we still find a negative relationship for regional unemployment rates, although the effect is more significant for individuals living in couple (e.g., 0.06 and 0.08 fewer hours per day devoted to personal care for individuals

\footnotetext{
${ }^{7}$ Hamermesh (2000) finds evidence for the US that couples arrange their work schedules to allow time for leisure that they consume jointly, and Halberg (2003) finds a positive effect of coordination on synchronous leisure, with market work and leisure timing being intra-household dependent.
} 
not living, and living in couple, respectively). Finally, we find specific effects for unemployed men living as part of a couple, as a one-percentage-point increase in the unemployment rate of the region is associated with an increase and a decrease of 0.05 hours per day devoted to household production and leisure, respectively.

For unemployed women, we find different effects of regional unemployment rates, depending on whether the individuals live as part of a couple, or not. We find positive relationships between regional unemployment rates and household production, on the one hand, and negative relationships between regional unemployment rates and leisure, on the other. However, we find that these relationships differ by civic status, and while the positive relationship between regional unemployment rates and household production is more significant for unemployed women living in couple, the negative relationship between regional unemployment rates and leisure is less so for unemployed women living in couple. Additionally, we find a specific relationship for unemployed women living in couple, as shown by the negative and statistically significant coefficient for regional unemployment rates and time devoted to study by women living in couple. Finally, while we find a positive relationship between regional unemployment rates and time spent on personal care, this relationship is less significant for unemployed women living in couple.

A one-percentage-point increase in the unemployment rate of the region is associated with increases of 0.03 and 0.07 hours per day in household production and personal care, respectively, of women not living in couple, while the same increase is associated with increases of 0.07 and 0.02 more hours per day in household production and personal care, respectively. Furthermore, we find that a one-percentage-point increase in the unemployment rate of the region is associated with decreases in leisure and study, but while the effect in leisure is concentrated for all unemployed women ( 0.11 fewer hours per day), the effect on time spent in study is concentrated in unemployed women living in couple (0.04 fewer hours per day).

\subsection{Regional unemployment rates and income shocks}

Unemployment for individuals implies an income shock for those who do not have unemployment benefits as labour market earnings disappear. In this situation, where household income decreases as a consequence of unemployment, consumption patterns change and, in households where there are unemployed individuals, time-intensive 
commodities are produced more (Ahn, Jimeno and Ugidos, 2004). Thus, income shocks influence the time allocation decisions of individuals, consistent with Becker's household production theory (Becker, 1965). Under this framework, the extent to which unemployed individuals have a partner to support them economically may influence how these unemployed individuals allocate their time, and it may also influence to some extent how sensitive they are to others' unemployment, given the previously-reported relationship between the time allocation decisions of the unemployed and others' unemployment.

Unfortunately, we do not have information on whether the unemployed are receiving unemployment benefits, or not. Hence, we have estimated equation (1) including a dummy variable to control for whether or not the partner's respondent is working, interacting this dummy variable with the variable measuring regional unemployment rates, to analyze whether the effects of regional unemployment rates differ according to the employment status of the respondent's partner. Households where one of the partners is employed will almost certainly experience a lower decrease in income (smaller income shock) compared to households where both partners are unemployed, or where there is a single unemployed individual. To analyze this, we create a dummy variable to indicate whether the respondent's partner is working (1), or not (0).

Panels A and B in Table 6 show the results of estimating equation (1) including the partner's employment status and its interaction with the regional unemployment rate for men and women (see Tables C7 and C8 for results for the rest of variables). For unemployed men, we observe that the relationship between regional unemployment rates and the time devoted to study and personal care are positive and negative, respectively, independently of whether there is a working partner, or not. The only difference we find considering the working status of the partner is for leisure, where we find a negative effect of regional unemployment rates only for those individuals who have a working partner. Hence, a one-percentage-point increase in the unemployment rate of the region is associated with an increase and a decrease of 0.06 hours per day to study and personal care, respectively, by unemployed men, with no difference in the effect between men with and without working partners. Furthermore, we find a specific effect for unemployed men having a working partner, as a one-percentage-point increase in the unemployment rate of the region is associated with a decrease of 0.02 hours per day devoted to leisure. 
For unemployed women we find different effects of regional unemployment rates, depending on whether they have a working partner, or not. We find positive relationships between regional unemployment rates and household production, on the one hand, and negative relationships between regional unemployment rates and leisure, on the other, although the negative relationship for leisure is smaller for unemployed women having a working partner. Additionally, we find a specific relationship for unemployed women having a working partner, as shown by the negative and statistically significant coefficient for regional unemployment rates and time devoted to study by women having a working partner. Finally, while we find a positive relationship between regional unemployment rates and time in personal care, that relationship is less significant for unemployed women having a working partner.

A one-percentage-point increase in the unemployment rate of the region is associated with an increase of 0.05 hours per day in household production of all unemployed women, while it is associated with an increase of 0.06 and 0.02 hours per day in personal care for unemployed women not having, and having, a working partner, respectively. Furthermore, we find that a one-percentage-point increase in the unemployment rate of the region is associated with decreases in time spent in leisure and study, but while the effect on leisure depends on the presence of a working partner (0.11 and 0.08 fewer hours per day for unemployed women not having, and having, a working partner, respectively), the effect on study is concentrated in unemployed women having a working partner (0.02 fewer hours per day).

\subsection{Interpretation of results}

Our results based on differences in civic status and the working status of the partner can be used to test whether synchronization with others (greater availability of mates for time activities, Jenkins and Osberg 2005) is at the root of the observed relationship for both men and women. If this is the case, we would expect to find that the time devoted to leisure is greater in regions with higher unemployment rates, given that there are more available mates for time activities. Additionally, the effects should be stronger for individuals living in couples, given that they would try to time activities in concert with their partners. However, the fact that we find no effect of regional unemployment rates on leisure for unemployed men, and that the effect for women's leisure time is negative, indicates that synchronization of activities is not the main channel through which 
regional unemployment rates affect the time-allocation decisions of individuals. This hypothesis is reinforced by the fact that, after controlling for whether individuals live in couple, the effect of regional unemployment rates on the time devoted to leisure by women is still negative for those living in couples, indicating that the overall effect is negative in all cases of women.

Another channel through which regional unemployment rates may affect the time allocation decisions of the unemployed would be consumption smoothing, in which households attempt to increase their time spent on household production, allowing them to reduce the market expenditures needed to maintain their consumption. We find that unemployed men living in couple devote more time to household production, while unemployed women in the same situation devote more time to household production, compared to their counterparts not living in couple. We interpret this result as indicating that with higher regional unemployment rates there is a lower availability of jobs for the unemployed, decreasing individual expectations of finding a job. Thus, we consider that one of the channels through which regional unemployment rates affect the time allocation decisions of the unemployed is consumption smoothing. This would also explain why unemployed women living in couple, and with working partners, devote less time to study, given the expenditures associated with study.

\section{CONCLUSIONS}

Unemployment is considered one of the strongest correlates of individual well-being, and economists have long debated its causes and consequences. Prior research has studied the relationship between regional unemployment rates and individual wellbeing. However, previous research has focused on individual well-being, without considering other dimensions of individual behavior, such as time-allocation decisions. We analyze how other's unemployment - regional unemployment rates - is related to the time allocation decisions of the unemployed in Spain. Using the Spanish Time Use Survey (STUS) 2002-2003 and 2009-2010, we find that higher unemployment rates of the region are associated with increases in the time devoted to study by men, and to household production by women, with concomitant decreases in the time devoted to personal care by men and leisure by women. Our results are consistent with alternative 
specifications where we include heterogeneous effects based on urban residence, civic status, and the working status of the partner.

We contribute to the literature on how others' unemployment relates to the wellbeing of the unemployed (Di Tella, MacCulloch and Oswald, 2001; Clark, 2003). We interpret our results as evidence that these effects are due to dis-couragement of the unemployed living in regions with high unemployment rates, while we find no evidence of a "social-norm effect". Our results are in line with Burda and Hamermesh (2010) and Aguiar, Hurst and Karabarbournis (2012), who find that foregone market work hours due to the business cycle are reallocated to non-market production.

However, previous studies have found that personal care and leisure rank among the most enjoyable activities, while household production and study rank among the least enjoyable activities (Kahneman et al., 2004, Kahneman and Krueger, 2006, Krueger, 2007, Knabe et al., 2010), which may indicate that other's unemployment also has a negative effect on the well-being of the unemployed. Thus, although there may be consumption smoothing, a negative effect on the well-being of the unemployed can be argued if we look at instant enjoyment of daily activities, and these two effects should be considered in the analysis of the effects of the business cycle on the well-being of the unemployed.

Additionally, we find gender differences in the relationship between regional unemployment rates and time allocation decisions of the unemployed, which is consistent with the fact that Spain has been classified as "traditional" in terms of the gender distribution of household labor (Sevilla-Sanz, 2010; Gimenez-Nadal, Molina and Sevilla-Sanz, 2012). Other countries have been classified as being more egalitarian in the gender distribution of household labor, with different "gender norms", and thus the time devoted to household production by unemployed men may be also affected by regional unemployment rates in those countries. The fact that we find differential effects by gender may indicate that further analysis for other countries is needed, to determine whether the same gender effects are present, or not.

One limitation of our analysis is that our data is a cross-section of individuals, and it does not allow us to identify the effect of unemployment rates net of (permanent) individual heterogeneity in preferences (Manski, 2000). This is particularly important in our context, since it could be that unemployment rates and individual preferences regarding market work and leisure time are correlated. As shown by Burda and 
Hamermesh (2010), it could be that social norms about preferences for work and leisure differ geographically and, in regions with high unemployment rates, individuals have a higher preference for leisure time and a lower preference for the labor market, which would explain the fact that individuals may be less productive - and thus have a higher probability of being unemployed. Unfortunately, the STUS does not contain information on individual preferences regarding time allocation decisions, and our results would also be capturing the effects of individual preferences on time use. Thus, we cannot talk definitively about a causal relationship between unemployment rates and the time allocation decisions of the unemployed, and more research on this topic is needed.

\section{REFERENCES}

Ahn, N., J.F. Jimeno and A. Ugidos (2004) "Mondays in the sun: Unemployment, time use and consumption patterns in Spain” in Time Use in Economics, Hamermesh and Pfann (Eds.), Elsevier.

Aguiar, M., and E. Hurst. (2007). "Measuring Trends in Leisure: The Allocation of Time Over Five Decades,” Quarterly Journal of Economics 122(3), 969-1006.

Aguiar, M., E. Hurst and L. Karabarbounis (2012). “Time Use During Recessions,” American Economic Review (forthcoming).

Becker, G.S. (1965). “A Theory of the Allocation of Time,” Economic Journal 75, 493517.

Bianchi, S., M.A. Milkie, L.C. Sayer and J.P. Robinson (2000). "Is Anyone Doing the Housework? Trends in the Gender Division of Household Labor,” Social Forces 79, 191-228.

Black, D., and V. Henderson (1999). "Spatial evolution of population and industry in the United States,” American Economic Review 89, 321-327.

Bonke, J. (2005). "Paid work and unpaid work: diary information versus questionnaire information,” Social Indicators Research 70: 349-368.

Burda, M., and D. Hamermesh (2010). “Unemployment, Market Work and Household Production,” Economics Letters 107, 131-133. 
Burda, M., D. Hamermesh and P. Weil (2008). "The Distribution of Total Work in the U.S. and E.U.," in Working Hours and Job Sharing in the EU and USA: Are Europeans Lazy? or Americans Crazy?, edited by T. Boeri, Michael Burda and Francis Kramarz. Oxford: Oxford University Press.

Clark, A. (2003). "Unemployment as a social norm: psychological evidence from panel data,” Journal of Labor Economics 21, 323-351.

Connelly, R., and J. Kimmel (2009). “Spousal Influences on parent's non-market time choices," Review of Economics of the Household 7, 361-394.

Desmet, K., and M. Fafchamps (2005). "Changes in the spatial concentration of employment across US counties: a sectoral analysis 1972-2000,” Journal of Economic Geography 5, 261-284.

Di Tella, R., R. MacCulloch and A. Oswald (2001). "Preferences over inflation and unemployment: evidence from surveys of happiness," American Economic Review 91, 335-341.

Fernández-Kranz, D., and N. Rodríguez-Planas (2011) “The part-time pay penalty in a segmented labor market," Labour Economics 18, 837-844.

Foster, G., and C. Kalenkoski (2013). "Tobit or OLS? An empirical evaluation under different diary window lengths,” Applied Economics 45, 2994-3010.

Frazis, H., and J. Stewart (2012). "How to Think About Time-Use Data: What Inferences Can We Make About Long- and Short-Run Time Use from Time Use Diaries?” Annals of Economics and Statistics 105/106, 231-246.

Gershuny, J. (2009) "Veblen in reverse: Evidence from the multinational time-use archive,” Social Indicators Research 93, 37-45.

Gershuny, J. (2012). “Too Many Zeros: A Method for Estimating Long-term Time-use from Short Diaries,” Annals of Economics and Statistics 105/106, 247-270.

Gimenez-Nadal, J.I., M. Marcen and R. Ortega-Lapiedra (2010) "How do children affect parents’ allocation of time?” Applied Economic Letters 17, 1715-1719.

Gimenez-Nadal, J.I., and R. Ortega-Lapiedra (2010) "Self-employment and Time Stress: the Effect of Leisure Quality,” Applied Economics Letters 17, 1735-1738. 
Gimenez-Nadal, J.I., M. Marcen and A. Sevilla-Sanz (2010) "The Time-Crunch Paradox,” Social Indicators Research 102, 181-196.

Gimenez-Nadal, J.I., A. Sevilla-Sanz and J.A. Molina (2012). "Social Norms, Partnerships and Children,” Review of Economics of the Household 10, 215-236.

Gimenez-Nadal, J.I., and A. Sevilla (2012). “Trends in time allocation: A cross-country analysis,” European Economic Review 56, 1338-1359.

Guryan, J., E. Hurst and M. Kearney (2008). "Parental Education and Parental Time with Children,” Journal of Economic Perspectives 22, 23-46.

Halberg, D. (2003). “Synchronous Leisure, Jointness, and Household Labor Supply,” Labour Economics 10, 185-202.

Hamermesh, D. (2000). “Togetherness: Spouses' Synchronous Leisure and the Impact of Children,” NBER Working Paper W7455.

Instituto Nacional de Estadistica, (2011). www.ine.es

Jenkins, S., and L. Osberg (2005). "Nobody to Play with? The Implicatons of Leisure Coordination,” in The Economics of Time Use, eds. Daniel Hamermesh and Gerard Pfann, Amsterdam: Elsevier.

Juster, T., and F. Stafford (1985). Time, Goods, and Well-Being, Ann Arbor, MI: Institute for Social Research.

Kahneman, D., and A. Krueger (2006). "Developments in the Measurement of Subjective Well-Being,” Journal of Economic Perspectives 20, 3-24.

Kahneman, D., and A. Krueger (2006). "Developments in the Measurement of Subjective Well-Being,” Journal of Economic Perspectives 20, 3-24.

Kahneman, D., A. Krueger, D. Schkade, N. Schwarz and A. Stone (2004). “A Survey Method for Characterizing Daily Life Experience: The Day Reconstruction Method,” Science 3, 1776-1780.

Kalenkoski, C., D. Rivar and L.S. Stratton (2005) "Parental Child Care in Single-Parent, Cohabiting, and Married Couples Families: Time-Diary Evidence from the United Kingdom,” American Economic Review 95, 194-198. 
Kalenkoski, C., D. Ribar and L. Stratton (2009). “The influence of wages on parents’ allocations of time to child care and market work in the United Kingdom,” Journal of Population Economics 22, 399-419.

Knabe, A., S. Rätzel, R. Schöb und J. Weimann (2010). "Dissatisfied with life, but having a good day: time-use and well-being of the unemployed,” Economic Journal 120, 867-889.

Krueger, A. (2007). “Are We Having More Fun Yet? Categorizing and Evaluating Changes in Time Allocation,” Brookings Papers on Economic Activity 2,193-217.

Manski, C.F. (2000). "Economic analysis of social interactions,” Journal of Economic Perspectives 14, 115-136.

Ottaviano, G., and D. Pinelli (2006). "Market potential and productivity: evidence from Finnish regions,” Regional Science and Urban Economics 36, 636-657.

Partridge, M.D., D.S. Rickman, K. Ali, and M.R. Olfert (2008a). “Employment growth in the American urban hierarchy: long live distance," The B.E. Journal of Macroeconomics 8, Available at: http://www.bepress.com/bejm/vol8/iss1/art10.

(2008b). "Lost in space: population dynamics in the American hinterlands and small cities,” Journal of Economic Geography 8, 727-757. (2010). "Recent spatial growth dynamics in wages and housing costs: Proximity to urban production externalities and consumer amenities ," Regional Science and Urban Economics 40, 440-452.

Robinson, J., and G. Godbey (1997). Time for Life: the Surprising Ways Americans Use Their Time, University Park, PA: Pennsylvania State University Press, second edition.

Sevilla-Sanz, A. (2010)."Household division of labor and cross-country differences in household formation rates", Journal of Population Economics 23, 225-249.

Sevilla-Sanz, A., R. Fernandez and J. Gimenez-Nadal (2010). "Gender Roles and the Household Division of Unpaid Work: Evidence from the Spanish Time Use Survey,” Feminist Economics 16, 137-184.

Tobin, J. (1958). “Estimation of relationships for limited dependent variables,” Econometrica 26, 24-36.

Väisänen, P. (2006). "Mean of episode lenghts as a quality indicator of time use diaries,” Paper presented at the 28th IATUR Annual Conference, Copenhagen. 
Yee-Kan, M. (2008). "Measuring housework participation: the gap between "stylised" questionnaire estimates and diary-based estimates,” Social Indicators Research 86: 381-400. 
Figure 1. Time use of Spanish unemployed men and Regional unemployment rates
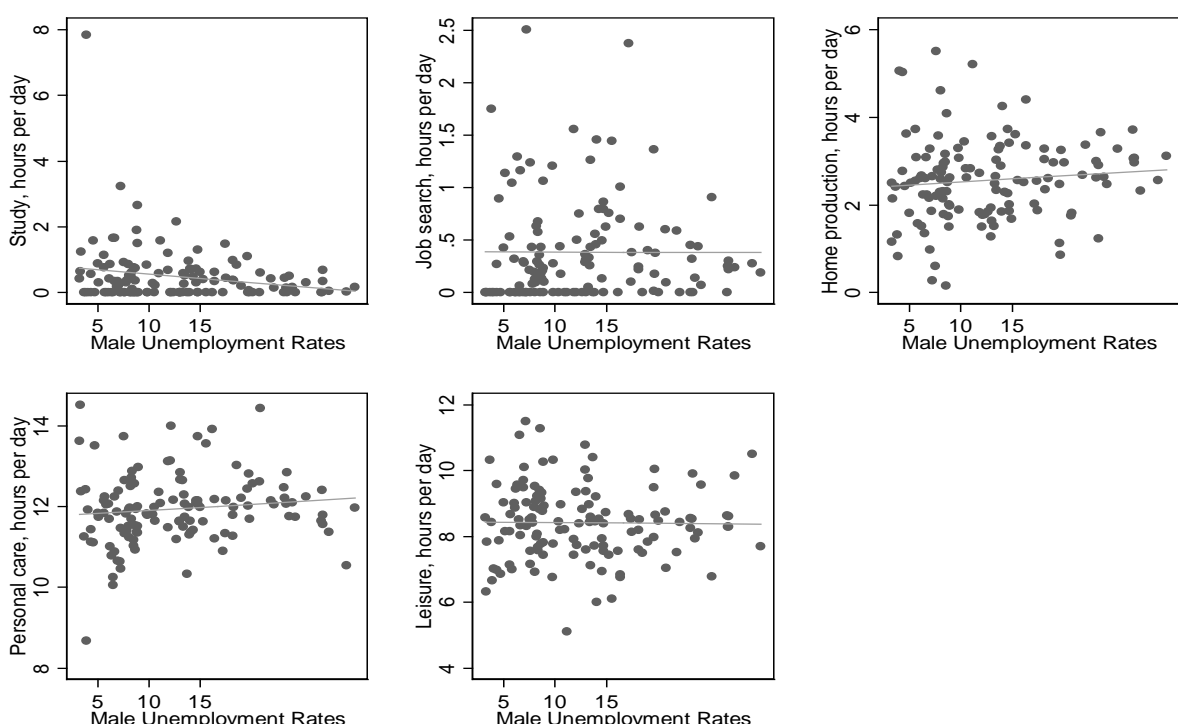

Notes: Sample consists of men aged 21-65 who are unemployed, from the Spanish Time Use Survey (STUS) 2002-2003 and 2009-2010. Regional Unemployment Rates comes from the Spanish Statistical Office (Instituto Nacional de Estadística), defined at the level of the 17 autonomous regions in Spain (Ceuta and Melilla are excluded from the analysis). Definitions of time use variables can be found in Appendix Table A1. Time use variables are measured in hours per day. We compute mean values of each variable for each Spanish region.

Figure 2. Time use of Spanish unemployed women and Regional unemployment rates
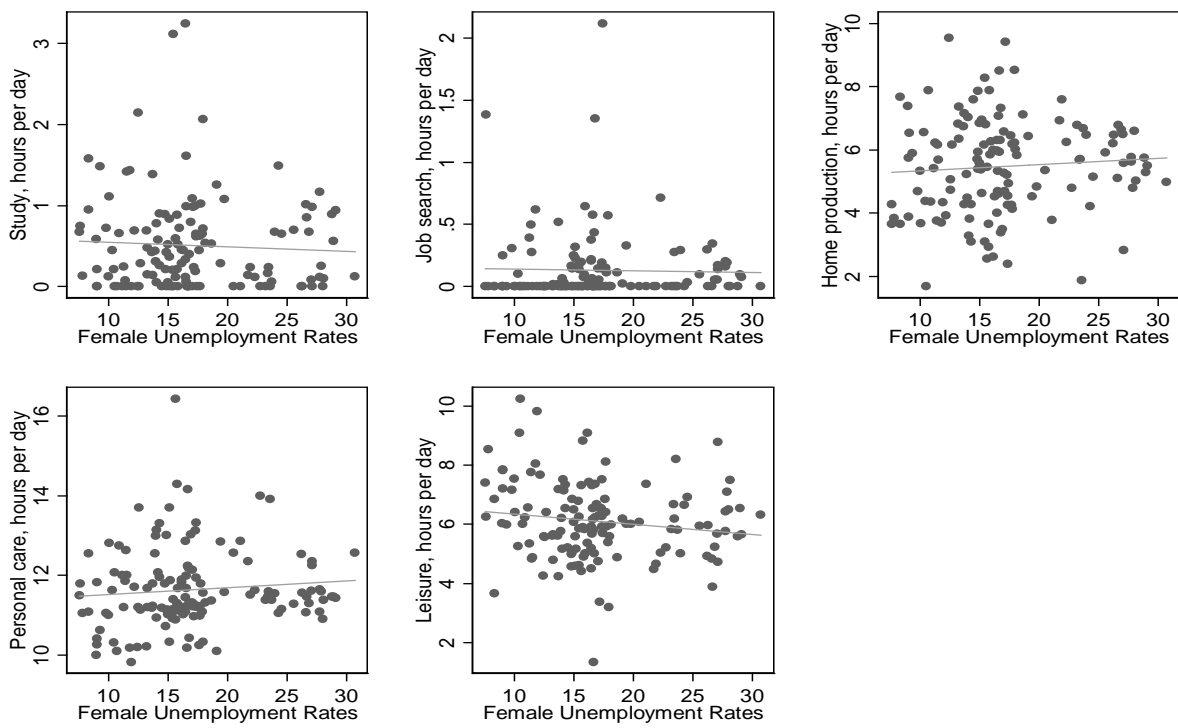

Notes: Sample consists of women aged 21-65 who are unemployed from the Spanish Time Use Survey (STUS) 2002-2003 and 2009-2010. Regional Unemployment Rates comes from the Spanish Statistical Office (Instituto Nacional de Estadística), defined at the level of the 17 autonomous regions in Spain (Ceuta and Melilla are excluded from the analysis). Definitions of time use variables can be found in Appendix Table A1. Time use variables are measured in hours per day. We compute mean values of each variable for each Spanish region. 
Table 1. Hours per day devoted to activities, by gender

\begin{tabular}{|c|c|c|c|}
\hline & \multicolumn{2}{|c|}{ (1) } & $(2)$ \\
\hline & Hours & per day & $\begin{array}{l}\text { Participation in the } \\
\text { day of the survey }\end{array}$ \\
\hline \multirow[t]{2}{*}{ - } & \multicolumn{3}{|c|}{ Panel A: Men } \\
\hline & \multicolumn{3}{|l|}{ Mean } \\
\hline Study & 0.431 & $(1.651)$ & $8.65 \%$ \\
\hline Job search & 0.453 & $(1.403)$ & $12.58 \%$ \\
\hline Household production & 2.630 & $(2.772)$ & $80.20 \%$ \\
\hline Personal care & 11.889 & $(2.371)$ & $100.00 \%$ \\
\hline Leisure & 8.355 & $(3.332)$ & $99.15 \%$ \\
\hline Overall Regional Unemployment Rate & 16.868 & $(0.214)$ & \\
\hline N Observations & \multicolumn{3}{|r|}{1,884} \\
\hline \multirow[t]{2}{*}{-} & \multicolumn{3}{|c|}{ Panel B: Women } \\
\hline & Mean & $\underline{S D}$ & \\
\hline Study & 0.586 & $(1.832)$ & $11.93 \%$ \\
\hline Job search & 0.095 & $(0.599)$ & $5.18 \%$ \\
\hline Household production & 5.983 & (3.464) & $96.47 \%$ \\
\hline Personal care & 11.434 & $(2.113)$ & $100.00 \%$ \\
\hline Leisure & 5.770 & $(3.033)$ & $99.68 \%$ \\
\hline Overall Regional Unemployment Rate & 24.181 & $(0.137)$ & \\
\hline N Observations & \multicolumn{3}{|r|}{2,238} \\
\hline \multicolumn{4}{|c|}{$\begin{array}{l}\text { Notes: Standard deviations in parentheses. Sample consists of respondents aged 21-65 } \\
\text { who are unemployed, from the Spanish Time Use Survey (STUS) 2002-2003 and 2009- } \\
2010 \text {. Regional Unemployment Rates comes from the Spanish Statistical Office (Instituto } \\
\text { Nacional de Estadística), defined at the level of the } 17 \text { autonomous regions in Spain } \\
\text { (Ceuta and Melilla are excluded from the analysis). Definitions of time use variables can } \\
\text { be found in Appendix Table B1. Time use variables are measured in hours per day. }\end{array}$} \\
\hline
\end{tabular}


Table 2. Time devoted to activities and regional unemployment rates, men

\begin{tabular}{|c|c|c|c|c|c|}
\hline Men & $\begin{array}{c}\text { (1) } \\
\text { Study }\end{array}$ & $\begin{array}{c}(2) \\
\text { Job } \\
\text { Search }\end{array}$ & $\begin{array}{c}(3) \\
\text { Household } \\
\text { production }\end{array}$ & $\begin{array}{c}(4) \\
\text { Personal } \\
\text { Care }\end{array}$ & Leisure \\
\hline Regional unemployment Rates & $\begin{array}{c}0.056 * * \\
(0.023)\end{array}$ & $\begin{array}{c}0.025 \\
(0.022)\end{array}$ & $\begin{array}{c}0.009 \\
(0.039)\end{array}$ & $\begin{array}{c}-0.069 * * \\
(0.028)\end{array}$ & $\begin{array}{l}-0.029 \\
(0.032)\end{array}$ \\
\hline Age & $\begin{array}{c}-0.032 \\
(0.024)\end{array}$ & $\begin{array}{l}-0.016 \\
(0.015)\end{array}$ & $\begin{array}{c}0.177 * * * \\
(0.035)\end{array}$ & $\begin{array}{c}-0.028 \\
(0.021)\end{array}$ & $\begin{array}{c}-0.114 \\
(0.078)\end{array}$ \\
\hline Age squared & $\begin{array}{c}0.023 \\
(0.027)\end{array}$ & $\begin{array}{c}0.001 \\
(0.012)\end{array}$ & $\begin{array}{c}-0.166^{* * *} \\
(0.049)\end{array}$ & $\begin{array}{c}0.028 \\
(0.024)\end{array}$ & $\begin{array}{c}0.130 \\
(0.089)\end{array}$ \\
\hline Secondary education & $\begin{array}{c}0.229 * * * \\
(0.057)\end{array}$ & $\begin{array}{l}-0.060 \\
(0.039)\end{array}$ & $\begin{array}{c}0.512 * * * \\
(0.147)\end{array}$ & $\begin{array}{c}-0.472 * * * \\
(0.064)\end{array}$ & $\begin{array}{l}-0.246 \\
(0.227)\end{array}$ \\
\hline University education & $\begin{array}{c}1.127 * * * \\
(0.167)\end{array}$ & $\begin{array}{l}-0.097 \\
(0.068)\end{array}$ & $\begin{array}{c}0.625 * * * \\
(0.157)\end{array}$ & $\begin{array}{c}-0.708^{* * *} \\
(0.185)\end{array}$ & $\begin{array}{c}-0.765^{* * *} \\
(0.115)\end{array}$ \\
\hline Number of children & $\begin{array}{c}-0.072 * * * \\
(0.012)\end{array}$ & $\begin{array}{c}0.038 \\
(0.027)\end{array}$ & $\begin{array}{c}0.655^{* * * *} \\
(0.051)\end{array}$ & $\begin{array}{c}-0.119 * * * \\
(0.032)\end{array}$ & $\begin{array}{c}-0.522^{* * *} \\
(0.046)\end{array}$ \\
\hline Paid housekeeping & $\begin{array}{c}0.015 \\
(0.141)\end{array}$ & $\begin{array}{l}-0.075 \\
(0.154)\end{array}$ & $\begin{array}{c}0.650 \\
(0.388)\end{array}$ & $\begin{array}{c}-0.398 \\
(0.489)\end{array}$ & $\begin{array}{c}-0.107 \\
(0.464)\end{array}$ \\
\hline Bad health & $\begin{array}{c}0.111 \\
(0.117)\end{array}$ & $\begin{array}{l}-0.078 \\
(0.104)\end{array}$ & $\begin{array}{l}0.219 * \\
(0.118)\end{array}$ & $\begin{array}{l}-0.040 \\
(0.274)\end{array}$ & $\begin{array}{l}-0.013 \\
(0.270)\end{array}$ \\
\hline Poor health & $\begin{array}{l}-0.030 \\
(0.120)\end{array}$ & $\begin{array}{l}-0.010 \\
(0.100)\end{array}$ & $\begin{array}{c}0.194 \\
(0.177)\end{array}$ & $\begin{array}{c}0.081 \\
(0.262)\end{array}$ & $\begin{array}{c}0.033 \\
(0.199)\end{array}$ \\
\hline Good health & $\begin{array}{c}-0.217 * * * \\
(0.062)\end{array}$ & $\begin{array}{c}-0.021 \\
(0.041)\end{array}$ & $\begin{array}{c}0.216 \\
(0.275)\end{array}$ & $\begin{array}{c}0.785^{* * *} \\
(0.191)\end{array}$ & $\begin{array}{l}-0.447 \\
(0.277)\end{array}$ \\
\hline Very good health & $\begin{array}{c}0.267 \\
(0.423)\end{array}$ & $\begin{array}{c}-0.480 * * * \\
(0.078)\end{array}$ & $\begin{array}{l}-1.288 \\
(0.777)\end{array}$ & $\begin{array}{c}1.003 \\
(0.846)\end{array}$ & $\begin{array}{c}0.912 \\
(1.071)\end{array}$ \\
\hline Hhld income 1201-2000 € & $\begin{array}{c}0.422 * * * \\
(0.105)\end{array}$ & $\begin{array}{c}-0.381^{* * *} \\
(0.060)\end{array}$ & $\begin{array}{c}0.007 \\
(0.181)\end{array}$ & $\begin{array}{l}-0.055 \\
(0.143)\end{array}$ & $\begin{array}{c}0.025 \\
(0.280)\end{array}$ \\
\hline Hhld income 2001-3000 € & $\begin{array}{c}0.010 \\
(0.153)\end{array}$ & $\begin{array}{l}-0.061 \\
(0.080)\end{array}$ & $\begin{array}{c}-0.359 \\
(0.403)\end{array}$ & $\begin{array}{c}0.024 \\
(0.367)\end{array}$ & $\begin{array}{c}0.381 \\
(0.451)\end{array}$ \\
\hline Hhld income $>3000 €$ & $\begin{array}{c}0.114 \\
(0.504)\end{array}$ & $\begin{array}{c}-0.131 \\
(0.098)\end{array}$ & $\begin{array}{c}-1.580^{* * *} \\
(0.431)\end{array}$ & $\begin{array}{c}1.239 * * * \\
(0.256)\end{array}$ & $\begin{array}{c}0.379 \\
(0.234)\end{array}$ \\
\hline Consumer price index & $\begin{array}{l}-0.016 \\
(0.019)\end{array}$ & $\begin{array}{c}0.027^{* *} \\
(0.010)\end{array}$ & $\begin{array}{c}0.032 \\
(0.032)\end{array}$ & $\begin{array}{c}0.004 \\
(0.024)\end{array}$ & $\begin{array}{l}-0.073^{*} \\
(0.042)\end{array}$ \\
\hline Gross domestic product & $\begin{array}{l}-0.025^{*} \\
(0.012)\end{array}$ & $\begin{array}{c}-0.010 \\
(0.010)\end{array}$ & $\begin{array}{l}-0.010 \\
(0.021)\end{array}$ & $\begin{array}{l}0.023^{*} \\
(0.011)\end{array}$ & $\begin{array}{c}0.027 \\
(0.020)\end{array}$ \\
\hline Activity rate of the region & $\begin{array}{c}-0.012 \\
(0.014)\end{array}$ & $\begin{array}{c}0.010 \\
(0.018)\end{array}$ & $\begin{array}{c}-0.041 * \\
(0.023)\end{array}$ & $\begin{array}{l}0.048^{*} \\
(0.026)\end{array}$ & $\begin{array}{c}0.011 \\
(0.038)\end{array}$ \\
\hline Income per capita & $\begin{array}{c}0.014^{* *} \\
(0.005)\end{array}$ & $\begin{array}{c}0.016^{* *} \\
(0.007)\end{array}$ & $\begin{array}{c}0.008 \\
(0.008)\end{array}$ & $\begin{array}{c}-0.016 * * \\
(0.006)\end{array}$ & $\begin{array}{c}-0.027^{* * * *} \\
(0.008)\end{array}$ \\
\hline Divorce rates & $\begin{array}{c}-0.050 \\
(0.097)\end{array}$ & $\begin{array}{c}-0.253^{* *} \\
(0.108)\end{array}$ & $\begin{array}{c}0.161 \\
(0.115)\end{array}$ & $\begin{array}{c}-0.102 \\
(0.107)\end{array}$ & $\begin{array}{c}0.334 \\
(0.222)\end{array}$ \\
\hline$\%$ people in region with very poor health & $\begin{array}{c}0.063 \\
(0.055)\end{array}$ & $\begin{array}{c}0.033 \\
(0.027)\end{array}$ & $\begin{array}{c}0.037 \\
(0.068)\end{array}$ & $\begin{array}{c}-0.098 * * \\
(0.043)\end{array}$ & $\begin{array}{l}-0.084 \\
(0.095)\end{array}$ \\
\hline$\%$ people in region with poor health & $\begin{array}{c}0.045 \\
(0.048)\end{array}$ & $\begin{array}{c}0.034 \\
(0.023)\end{array}$ & $\begin{array}{l}-0.012 \\
(0.058)\end{array}$ & $\begin{array}{c}-0.097 * * \\
(0.038)\end{array}$ & $\begin{array}{l}-0.027 \\
(0.079)\end{array}$ \\
\hline$\%$ people in region with good health & $\begin{array}{c}0.073 \\
(0.044)\end{array}$ & $\begin{array}{l}0.041 * \\
(0.022)\end{array}$ & $\begin{array}{l}-0.034 \\
(0.062)\end{array}$ & $\begin{array}{c}-0.113^{* * *} \\
(0.037)\end{array}$ & $\begin{array}{l}-0.031 \\
(0.077)\end{array}$ \\
\hline Share of public jobs relative to private & $\begin{array}{c}0.021^{* * *} \\
(0.006)\end{array}$ & $\begin{array}{c}0.010 \\
(0.009)\end{array}$ & $\begin{array}{c}0.008 \\
(0.009)\end{array}$ & $\begin{array}{c}-0.031 * * \\
(0.011)\end{array}$ & $\begin{array}{c}0.001 \\
(0.021)\end{array}$ \\
\hline Industrial production index & $\begin{array}{l}-0.004 \\
(0.008)\end{array}$ & $\begin{array}{l}-0.011^{*} \\
(0.006)\end{array}$ & $\begin{array}{c}0.032 * * * \\
(0.010)\end{array}$ & $\begin{array}{l}-0.011 \\
(0.013)\end{array}$ & $\begin{array}{c}0.007 \\
(0.018)\end{array}$ \\
\hline Industrial price index & $\begin{array}{c}-0.022 * * * \\
(0.006)\end{array}$ & $\begin{array}{c}-0.040 * * \\
(0.015)\end{array}$ & $\begin{array}{c}0.000 \\
(0.016)\end{array}$ & $\begin{array}{c}0.017 \\
(0.011)\end{array}$ & $\begin{array}{c}0.070 * * \\
(0.027)\end{array}$ \\
\hline Constant & $\begin{array}{l}-1.283 \\
(5.313)\end{array}$ & $\begin{array}{l}-1.384 \\
(2.808)\end{array}$ & $\begin{array}{l}-5.526 \\
(6.448)\end{array}$ & $\begin{array}{c}20.730 * * * \\
(4.635)\end{array}$ & $\begin{array}{l}14.188^{*} \\
(7.710)\end{array}$ \\
\hline $\begin{array}{l}\text { N Observations } \\
\text { R-squared }\end{array}$ & $\begin{array}{c}1,884 \\
0.11\end{array}$ & $\begin{array}{l}1,884 \\
0.073\end{array}$ & $\begin{array}{c}1,884 \\
0.13\end{array}$ & $\begin{array}{c}1,884 \\
0.07\end{array}$ & $\begin{array}{l}1,884 \\
0.092\end{array}$ \\
\hline
\end{tabular}

Notes: Robust standard errors in parentheses. Sample consists of respondents aged 21-65 who are unemployed, from the Spanish Time Use Survey (STUS) 2002-2003 and 2009-2010. Regional Unemployment Rates comes from the Spanish Statistical Office (Instituto Nacional de Estadística), defined at the level of the 17 autonomous regions in Spain (Ceuta and Melilla are excluded from the analysis). Definitions of time use variables can be found in Appendix Table B1. Time use variables are measured in hours per day. *Significant at the $90 \%$ level $* *$ Significant at the $95 \%$ level ***Significant at the $99 \%$ level. 
Table 3. Time devoted to activities and regional unemployment rates, women

\begin{tabular}{|c|c|c|c|c|c|}
\hline Women & $\begin{array}{c}\text { (1) } \\
\text { Study }\end{array}$ & $\begin{array}{c}(2) \\
\text { Job } \\
\text { Search }\end{array}$ & $\begin{array}{c}\text { (3) } \\
\text { Household } \\
\text { production }\end{array}$ & $\begin{array}{c}(4) \\
\text { Personal } \\
\text { Care }\end{array}$ & Leisure \\
\hline Regional unemployment Rates & $\begin{array}{l}-0.009 \\
(0.019)\end{array}$ & $\begin{array}{l}-0.003 \\
(0.007)\end{array}$ & $\begin{array}{c}0.053 * * * \\
(0.014)\end{array}$ & $\begin{array}{c}0.048 \\
(0.027)\end{array}$ & $\begin{array}{c}-0.104 * * * \\
(0.024)\end{array}$ \\
\hline Age & $\begin{array}{c}-0.067 * * * \\
(0.020)\end{array}$ & $\begin{array}{c}0.004 \\
(0.011)\end{array}$ & $\begin{array}{c}0.411^{* * *} \\
(0.017)\end{array}$ & $\begin{array}{c}-0.115^{* * *} \\
(0.019)\end{array}$ & $\begin{array}{c}-0.229 * * * \\
(0.023)\end{array}$ \\
\hline Age squared & $\begin{array}{c}0.064 * * \\
(0.025)\end{array}$ & $\begin{array}{l}-0.012 \\
(0.014)\end{array}$ & $\begin{array}{c}-0.432 * * * \\
(0.023)\end{array}$ & $\begin{array}{c}0.100 * * * \\
(0.031)\end{array}$ & $\begin{array}{c}0.272 * * * \\
(0.032)\end{array}$ \\
\hline Secondary education & $\begin{array}{l}0.112^{*} \\
(0.064)\end{array}$ & $\begin{array}{c}0.014 \\
(0.019)\end{array}$ & $\begin{array}{l}-0.038 \\
(0.077)\end{array}$ & $\begin{array}{c}0.071 \\
(0.059)\end{array}$ & $\begin{array}{c}-0.030 \\
(0.072)\end{array}$ \\
\hline University education & $\begin{array}{c}0.856 * * * \\
(0.059)\end{array}$ & $\begin{array}{l}-0.026 \\
(0.026)\end{array}$ & $\begin{array}{c}-0.758 * * * \\
(0.105)\end{array}$ & $\begin{array}{l}-0.145 \\
(0.109)\end{array}$ & $\begin{array}{c}0.217 \\
(0.174)\end{array}$ \\
\hline Number of children & $\begin{array}{c}-0.185 * * * \\
(0.007)\end{array}$ & $\begin{array}{c}-0.069 * * * \\
(0.015)\end{array}$ & $\begin{array}{c}1.225^{* * *} \\
(0.103)\end{array}$ & $\begin{array}{c}-0.164 * * * \\
(0.025)\end{array}$ & $\begin{array}{c}-0.739 * * * \\
(0.085)\end{array}$ \\
\hline Paid housekeeping & $\begin{array}{c}-0.375^{* *} \\
(0.148)\end{array}$ & $\begin{array}{c}-0.110^{* *} \\
(0.047)\end{array}$ & $\begin{array}{c}-0.598 \\
(0.524)\end{array}$ & $\begin{array}{c}-0.565^{* * *} \\
(0.177)\end{array}$ & $\begin{array}{c}1.497 * * \\
(0.531)\end{array}$ \\
\hline Bad health & $\begin{array}{c}0.372 * * \\
(0.138)\end{array}$ & $\begin{array}{c}-0.113 * * \\
(0.044)\end{array}$ & $\begin{array}{l}-0.181 \\
(0.160)\end{array}$ & $\begin{array}{c}-0.403^{* * *} \\
(0.129)\end{array}$ & $\begin{array}{c}0.211 \\
(0.130)\end{array}$ \\
\hline Poor health & $\begin{array}{c}0.114 \\
(0.077)\end{array}$ & $\begin{array}{l}-0.063 \\
(0.051)\end{array}$ & $\begin{array}{c}0.169 \\
(0.158)\end{array}$ & $\begin{array}{c}-0.417 * * * \\
(0.118)\end{array}$ & $\begin{array}{c}0.083 \\
(0.104)\end{array}$ \\
\hline Good health & $\begin{array}{l}-0.076 \\
(0.044)\end{array}$ & $\begin{array}{l}-0.006 \\
(0.039)\end{array}$ & $\begin{array}{c}-0.887 * * * \\
(0.253)\end{array}$ & $\begin{array}{c}0.087 \\
(0.091)\end{array}$ & $\begin{array}{c}0.740 * * * \\
(0.193)\end{array}$ \\
\hline Very good health & $\begin{array}{c}0.345 \\
(0.701)\end{array}$ & $\begin{array}{c}-0.185^{* * *} \\
(0.043)\end{array}$ & $\begin{array}{l}-1.060 \\
(0.663)\end{array}$ & $\begin{array}{c}3.033 * * * \\
(0.330)\end{array}$ & $\begin{array}{c}-2.035 * * * \\
(0.529)\end{array}$ \\
\hline Hhld income 1201-2000 $€$ & $\begin{array}{l}-0.030 \\
(0.076)\end{array}$ & $\begin{array}{c}0.033^{* *} \\
(0.014)\end{array}$ & $\begin{array}{c}0.046 \\
(0.039)\end{array}$ & $\begin{array}{l}-0.069 \\
(0.101)\end{array}$ & $\begin{array}{l}-0.014 \\
(0.064)\end{array}$ \\
\hline Hhld income 2001-3000 $€$ & $\begin{array}{l}-0.243 \\
(0.185)\end{array}$ & $\begin{array}{c}-0.103 * * \\
(0.042)\end{array}$ & $\begin{array}{c}0.087 \\
(0.293)\end{array}$ & $\begin{array}{c}0.285 \\
(0.220)\end{array}$ & $\begin{array}{l}-0.023 \\
(0.270)\end{array}$ \\
\hline Hhld income $>3000 €$ & $\begin{array}{l}-0.579 * \\
(0.321)\end{array}$ & $\begin{array}{l}-0.022 \\
(0.052)\end{array}$ & $\begin{array}{c}0.047 \\
(0.955)\end{array}$ & $\begin{array}{l}1.614^{* *} \\
(0.731)\end{array}$ & $\begin{array}{l}-1.031 \\
(0.688)\end{array}$ \\
\hline Consumer price index & $\begin{array}{l}-0.040 \\
(0.033)\end{array}$ & $\begin{array}{c}0.007 \\
(0.007)\end{array}$ & $\begin{array}{c}0.051 \\
(0.040)\end{array}$ & $\begin{array}{l}0.059 * \\
(0.030)\end{array}$ & $\begin{array}{c}-0.054^{* *} \\
(0.020)\end{array}$ \\
\hline Gross domestic product & $\begin{array}{l}0.015^{*} \\
(0.007)\end{array}$ & $\begin{array}{c}0.001 \\
(0.005)\end{array}$ & $\begin{array}{l}-0.022 \\
(0.016)\end{array}$ & $\begin{array}{c}-0.033^{* * *} \\
(0.008)\end{array}$ & $\begin{array}{c}0.044^{* *} \\
(0.018)\end{array}$ \\
\hline Activity rate of the region & $\begin{array}{c}0.018 \\
(0.048)\end{array}$ & $\begin{array}{l}0.033^{*} \\
(0.017)\end{array}$ & $\begin{array}{c}0.002 \\
(0.054)\end{array}$ & $\begin{array}{l}-0.057 \\
(0.048)\end{array}$ & $\begin{array}{l}-0.035 \\
(0.029)\end{array}$ \\
\hline Income per capita & $\begin{array}{l}-0.003 \\
(0.007)\end{array}$ & $\begin{array}{c}0.000 \\
(0.003)\end{array}$ & $\begin{array}{c}0.018 \\
(0.011)\end{array}$ & $\begin{array}{c}0.012 \\
(0.012)\end{array}$ & $\begin{array}{c}-0.035^{* *} \\
(0.012)\end{array}$ \\
\hline Divorce rates & $\begin{array}{l}-0.073 \\
(0.099)\end{array}$ & $\begin{array}{l}-0.126 * \\
(0.064)\end{array}$ & $\begin{array}{l}-0.110 \\
(0.163)\end{array}$ & $\begin{array}{l}-0.072 \\
(0.155)\end{array}$ & $\begin{array}{l}0.401^{*} \\
(0.210)\end{array}$ \\
\hline$\%$ people in region with very poor health & $\begin{array}{l}-0.022 \\
(0.025)\end{array}$ & $\begin{array}{c}0.006 \\
(0.013)\end{array}$ & $\begin{array}{l}-0.048 \\
(0.055)\end{array}$ & $\begin{array}{c}0.014 \\
(0.055)\end{array}$ & $\begin{array}{c}0.093 \\
(0.066)\end{array}$ \\
\hline$\%$ people in region with poor health & $\begin{array}{l}-0.030 \\
(0.024)\end{array}$ & $\begin{array}{c}0.012 \\
(0.014)\end{array}$ & $\begin{array}{l}-0.027 \\
(0.059)\end{array}$ & $\begin{array}{l}-0.009 \\
(0.061)\end{array}$ & $\begin{array}{c}0.084 \\
(0.065)\end{array}$ \\
\hline$\%$ people in region with good health & $\begin{array}{l}-0.051 \\
(0.040)\end{array}$ & $\begin{array}{c}0.022 \\
(0.019)\end{array}$ & $\begin{array}{c}0.043 \\
(0.101)\end{array}$ & $\begin{array}{l}-0.009 \\
(0.094)\end{array}$ & $\begin{array}{c}0.027 \\
(0.102)\end{array}$ \\
\hline Share of public jobs relative to private & $\begin{array}{c}0.028 \\
(0.023)\end{array}$ & $\begin{array}{l}0.007 \\
(0.007)\end{array}$ & $\begin{array}{l}-0.029 \\
(0.021)\end{array}$ & $\begin{array}{c}-0.062 * * * \\
(0.017)\end{array}$ & $\begin{array}{c}0.025 \\
(0.023)\end{array}$ \\
\hline Industrial production index & $\begin{array}{l}-0.016 \\
(0.021)\end{array}$ & $\begin{array}{l}-0.003 \\
(0.003)\end{array}$ & $\begin{array}{c}0.022 \\
(0.017)\end{array}$ & $\begin{array}{c}0.017 \\
(0.018)\end{array}$ & $\begin{array}{l}-0.013 \\
(0.019)\end{array}$ \\
\hline Industrial price index & $\begin{array}{c}0.024^{* * *} \\
(0.005)\end{array}$ & $\begin{array}{c}-0.015^{* * *} \\
(0.004)\end{array}$ & $\begin{array}{c}-0.063^{* * *} \\
(0.014)\end{array}$ & $\begin{array}{l}-0.008 \\
(0.012)\end{array}$ & $\begin{array}{c}0.067 * * * \\
(0.014)\end{array}$ \\
\hline Constant & $\begin{array}{c}6.587 \\
(4.374)\end{array}$ & $\begin{array}{l}-1.158 \\
(1.342)\end{array}$ & $\begin{array}{l}-3.848 \\
(5.493)\end{array}$ & $\begin{array}{l}11.229 * \\
(5.335)\end{array}$ & $\begin{array}{c}8.200 \\
(6.905)\end{array}$ \\
\hline $\begin{array}{c}\text { N Observations } \\
\text { R-squared }\end{array}$ & $\begin{array}{l}2,238 \\
0.099\end{array}$ & $\begin{array}{l}2,238 \\
0.039\end{array}$ & $\begin{array}{l}2,238 \\
0.325 \\
\end{array}$ & $\begin{array}{l}2,238 \\
0.134 \\
\end{array}$ & $\begin{array}{c}2,238 \\
0.16\end{array}$ \\
\hline
\end{tabular}

Notes: Robust standard errors in parentheses. Sample consists of respondents aged 21-65 who are unemployed, from the Spanish Time Use Survey (STUS) 2002-2003 and 2009-2010. Regional Unemployment Rates comes from the Spanish Statistical Office (Instituto Nacional de Estadística), defined at the level of the 17 autonomous regions in Spain (Ceuta and Melilla are excluded from the analysis). Definitions of time use variables can be found in Appendix Table B1. Time use variables are measured in hours per day. *Significant at the $90 \%$ level $* *$ Significant at the $95 \%$ level ***Significant at the $99 \%$ level. 
Table 4. Time devoted to activities and regional unemployment rates, urban status

\begin{tabular}{|c|c|c|c|c|c|}
\hline & $\begin{array}{c}\text { (1) } \\
\text { Study }\end{array}$ & $\begin{array}{c}(2) \\
\text { Job } \\
\text { Search }\end{array}$ & $\begin{array}{c}(3) \\
\text { Household } \\
\text { production }\end{array}$ & $\begin{array}{c}(4) \\
\text { Personal } \\
\text { Care }\end{array}$ & $\begin{array}{c}\text { (5) } \\
\text { Leisure }\end{array}$ \\
\hline & \multicolumn{5}{|c|}{ Panel A: Men } \\
\hline Regional unemployment Rates & $\begin{array}{c}0.058^{* * *} \\
(0.019)\end{array}$ & $\begin{array}{c}0.028 \\
(0.025)\end{array}$ & $\begin{array}{c}-0.011 \\
(0.041)\end{array}$ & $\begin{array}{c}-0.049 * \\
(0.025)\end{array}$ & $\begin{array}{l}-0.034 \\
(0.039)\end{array}$ \\
\hline Urban Area & $\begin{array}{c}0.283 * * \\
(0.114)\end{array}$ & $\begin{array}{c}0.415 * * \\
(0.192)\end{array}$ & $\begin{array}{l}-0.504 \\
(0.507)\end{array}$ & $\begin{array}{l}-0.174 \\
(0.147)\end{array}$ & $\begin{array}{l}-0.151 \\
(0.482)\end{array}$ \\
\hline Urban Area* Reg. Unemp. Rate & $\begin{array}{l}-0.007 \\
(0.007)\end{array}$ & $\begin{array}{l}-0.010 \\
(0.008)\end{array}$ & $\begin{array}{c}0.030 \\
(0.022)\end{array}$ & $\begin{array}{c}-0.018^{* *} \\
(0.008)\end{array}$ & $\begin{array}{c}0.008 \\
(0.020)\end{array}$ \\
\hline \multirow[t]{2}{*}{ R-squared } & $\begin{array}{l}1,884 \\
0.112\end{array}$ & $\begin{array}{c}1,884 \\
0.08\end{array}$ & $\begin{array}{r}1,884 \\
0.131 \\
\end{array}$ & $\begin{array}{l}1,884 \\
0.078\end{array}$ & $\begin{array}{l}1,884 \\
0.092\end{array}$ \\
\hline & \multicolumn{5}{|c|}{ Panel B: Women } \\
\hline Regional unemployment Rates & $\begin{array}{c}-0.021 \\
(0.021)\end{array}$ & $\begin{array}{l}-0.006 \\
(0.006)\end{array}$ & $\begin{array}{c}0.035 * \\
(0.019)\end{array}$ & $\begin{array}{c}0.056 * \\
(0.031)\end{array}$ & $\begin{array}{c}-0.080 * * * \\
(0.026)\end{array}$ \\
\hline Urban Area & $\begin{array}{l}-0.180 \\
(0.174)\end{array}$ & $\begin{array}{c}0.009 \\
(0.052)\end{array}$ & $\begin{array}{c}-0.871^{* * *} \\
(0.294)\end{array}$ & $\begin{array}{c}0.217 \\
(0.202)\end{array}$ & $\begin{array}{c}0.721 * * \\
(0.338)\end{array}$ \\
\hline Urban Area* Reg. Unemp. Rate & $\begin{array}{c}0.015^{* *} \\
(0.006)\end{array}$ & $\begin{array}{c}0.003 \\
(0.002)\end{array}$ & $\begin{array}{l}0.031 * * \\
(0.011)\end{array}$ & $\begin{array}{l}-0.011 \\
(0.008)\end{array}$ & $\begin{array}{c}-0.034 * * \\
(0.014)\end{array}$ \\
\hline N Observations & 2,238 & 2,238 & 2,238 & 2,238 & 2,238 \\
\hline R-squared & 0.102 & 0.043 & 0.326 & 0.134 & 0.161 \\
\hline
\end{tabular}

Notes: Robust standard errors in parentheses. Sample consists of respondents aged 21-65 who are unemployed, from the Spanish Time Use Survey (STUS) 2002-2003 and 2009-2010. Regional Unemployment Rates comes from the Spanish Statistical Office (Instituto Nacional de Estadística), defined at the level of the 17 autonomous regions in Spain (Ceuta and Melilla are excluded from the analysis). Definitions of time use variables can be found in Appendix Table B1. Time use variables are measured in hours per day. Urban area is a dummy variable that takes value " 1 " if the respondent lives in an urban area, and " 0 - otherwise. We use the aggregation level of the Multinational Time Use Study version of the STUS, which considers that the individual lives in an urban area if the city has 50,000 inhabitants or more, and in a rural area if there are less than 50,000 inhabitants. *Significant at the $90 \%$ level $* *$ Significant at the $95 \%$ level ***Significant at the $99 \%$ level.

Table 5. Time devoted to activities and regional unemployment rates, living in couple

\begin{tabular}{|c|c|c|c|c|c|}
\hline & $\begin{array}{c}\text { (1) } \\
\text { Study }\end{array}$ & $\begin{array}{c}(2) \\
\text { Job } \\
\text { Search }\end{array}$ & $\begin{array}{c}\text { (3) } \\
\text { Household } \\
\text { production }\end{array}$ & $\begin{array}{c}(4) \\
\text { Personal } \\
\text { Care } \\
\end{array}$ & $\begin{array}{c}\text { (5) } \\
\text { Leisure }\end{array}$ \\
\hline & \multicolumn{5}{|c|}{ Panel A: Men } \\
\hline Regional unemployment Rates & $\begin{array}{c}0.051^{* *} \\
(0.020)\end{array}$ & $\begin{array}{c}0.019 \\
(0.022)\end{array}$ & $\begin{array}{c}-0.036 \\
(0.041)\end{array}$ & $\begin{array}{c}-0.058 * * \\
(0.025)\end{array}$ & $\begin{array}{c}0.018 \\
(0.031)\end{array}$ \\
\hline In couple & $\begin{array}{l}-0.355^{*} \\
(0.190)\end{array}$ & $\begin{array}{c}0.101 \\
(0.110)\end{array}$ & $\begin{array}{c}0.363 \\
(0.224)\end{array}$ & $\begin{array}{c}0.599 * * * \\
(0.199)\end{array}$ & $\begin{array}{c}-0.629 * * \\
(0.222)\end{array}$ \\
\hline In couple*Reg. Unemp. Rate & $\begin{array}{c}0.011 \\
(0.008)\end{array}$ & $\begin{array}{c}0.006 \\
(0.007)\end{array}$ & $\begin{array}{c}0.051 * * * \\
(0.012)\end{array}$ & $\begin{array}{c}-0.022^{* *} \\
(0.010)\end{array}$ & $\begin{array}{c}-0.052 * * * \\
(0.015)\end{array}$ \\
\hline \multirow[t]{2}{*}{ R-squared } & $\begin{array}{l}1,884 \\
0.112\end{array}$ & $\begin{array}{l}1,884 \\
0.076\end{array}$ & $\begin{array}{c}1,884 \\
0.16\end{array}$ & $\begin{array}{l}1,884 \\
0.072\end{array}$ & $\begin{array}{l}1,884 \\
0.122\end{array}$ \\
\hline & \multicolumn{5}{|c|}{ Panel B: Women } \\
\hline Regional unemployment Rates & $\begin{array}{c}0.006 \\
(0.017)\end{array}$ & $\begin{array}{l}-0.007 \\
(0.008)\end{array}$ & $\begin{array}{c}0.033 * * \\
(0.013)\end{array}$ & $\begin{array}{c}0.071^{* *} \\
(0.029)\end{array}$ & $\begin{array}{c}-0.113^{* * *} \\
(0.024)\end{array}$ \\
\hline In couple & $\begin{array}{c}0.215 \\
(0.211)\end{array}$ & $\begin{array}{l}-0.385 * \\
(0.205)\end{array}$ & $\begin{array}{c}1.433 * * * \\
(0.368)\end{array}$ & $\begin{array}{c}0.878 * * * \\
(0.227)\end{array}$ & $\begin{array}{c}-1.641 * * * \\
(0.462)\end{array}$ \\
\hline In couple*Reg. Unemp. Rate & $\begin{array}{c}-0.035^{* * *} \\
(0.007)\end{array}$ & $\begin{array}{c}0.010 \\
(0.007)\end{array}$ & $\begin{array}{c}0.037 * * * \\
(0.009)\end{array}$ & $\begin{array}{c}-0.056^{* * *} \\
(0.008)\end{array}$ & $\begin{array}{c}0.028^{*} \\
(0.015)\end{array}$ \\
\hline N Observations & 2,238 & 2,238 & 2,238 & 2,238 & 2,238 \\
\hline R-squared & 0.102 & 0.043 & 0.326 & 0.134 & 0.161 \\
\hline
\end{tabular}

Notes: Robust standard errors in parentheses. Sample consists of respondents aged 21-65 who are unemployed, from the Spanish Time Use Survey (STUS) 2002-2003 and 2009-2010. Regional Unemployment Rates comes from the Spanish Statistical Office (Instituto Nacional de Estadística), defined at the level of the 17 autonomous regions in Spain (Ceuta and Melilla are excluded from the analysis). Definitions of time use variables can be found in Appendix Table B1. Time use variables are measured in hours per day. In couple is a dummy variable that takes value " 1 " if the respondent is married or cohabiting, and "0" otherwise. *Significant at the $90 \%$ level **Significant at the $95 \%$ level $* * *$ Significant at the $99 \%$ level. 
Table 6. Time devoted to activities and regional unemployment rates, working partner

\begin{tabular}{|c|c|c|c|c|c|}
\hline & $\begin{array}{c}(1) \\
\text { Study }\end{array}$ & $\begin{array}{c}(2) \\
\text { Job } \\
\text { Search }\end{array}$ & $\begin{array}{c}\text { (3) } \\
\text { Household } \\
\text { production }\end{array}$ & $\begin{array}{c}(4) \\
\text { Personal } \\
\text { Care } \\
\end{array}$ & $\begin{array}{c}(5) \\
\text { Leisure }\end{array}$ \\
\hline & \multicolumn{5}{|c|}{ Panel A: Men } \\
\hline Regional unemployment Rates & $\begin{array}{c}0.056 * * \\
(0.021)\end{array}$ & $\begin{array}{c}0.023 \\
(0.022)\end{array}$ & $\begin{array}{c}-0.006 \\
(0.042)\end{array}$ & $\begin{array}{c}-0.058^{* *} \\
(0.021)\end{array}$ & $\begin{array}{c}-0.017 \\
(0.028)\end{array}$ \\
\hline Partner working & $\begin{array}{c}0.138 \\
(0.112)\end{array}$ & $\begin{array}{l}-0.098 \\
(0.190)\end{array}$ & $\begin{array}{c}0.936 * * * \\
(0.232)\end{array}$ & $\begin{array}{c}0.168 \\
(0.454)\end{array}$ & $\begin{array}{c}-0.881^{* * *} \\
(0.256)\end{array}$ \\
\hline Partner working*Reg. Unemp. Rate & $\begin{array}{l}-0.005 \\
(0.007)\end{array}$ & $\begin{array}{c}0.005 \\
(0.011)\end{array}$ & $\begin{array}{c}0.011 \\
(0.015)\end{array}$ & $\begin{array}{l}-0.013 \\
(0.021)\end{array}$ & $\begin{array}{c}-0.021^{* *} \\
(0.008)\end{array}$ \\
\hline N Observations & 1,884 & 1,884 & 1,884 & 1,884 & 1,884 \\
\hline \multirow[t]{2}{*}{ R-squared } & 0.11 & 0.074 & 0.154 & 0.07 & 0.113 \\
\hline & \multicolumn{5}{|c|}{ Panel B: Women } \\
\hline Regional unemployment Rates & $\begin{array}{c}0.000 \\
(0.019)\end{array}$ & $\begin{array}{l}-0.004 \\
(0.007)\end{array}$ & $\begin{array}{c}0.047 * * * \\
(0.011)\end{array}$ & $\begin{array}{c}0.060^{* *} \\
(0.028)\end{array}$ & $\begin{array}{c}-0.113^{* * *} \\
(0.025)\end{array}$ \\
\hline Partner working & $\begin{array}{c}0.230 \\
(0.156)\end{array}$ & $\begin{array}{l}-0.216 \\
(0.152)\end{array}$ & $\begin{array}{c}1.213 * * * \\
(0.378)\end{array}$ & $\begin{array}{l}0.564^{*} \\
(0.273)\end{array}$ & $\begin{array}{c}-1.376 * * * \\
(0.406)\end{array}$ \\
\hline Partner working* Reg. Unemp. Rate & $\begin{array}{c}-0.024 * * * \\
(0.006)\end{array}$ & $\begin{array}{c}0.005 \\
(0.006)\end{array}$ & $\begin{array}{c}0.008 \\
(0.011)\end{array}$ & $\begin{array}{c}-0.035^{* * *} \\
(0.010)\end{array}$ & $\begin{array}{c}0.031 * * \\
(0.013)\end{array}$ \\
\hline N Observations & 2,238 & 2,238 & 2,238 & 2,238 & 2,238 \\
\hline R-squared & 0.107 & 0.044 & 0.354 & 0.139 & 0.168 \\
\hline
\end{tabular}

Notes: Robust standard errors in parentheses. Sample consists of respondents aged 21-65 who are unemployed, from the Spanish Time Use Survey (STUS) 2002-2003 and 2009-2010. Regional Unemployment Rates comes from the Spanish Statistical Office (Instituto Nacional de Estadística), defined at the level of the 17 autonomous regions in Spain (Ceuta and Melilla are excluded from the analysis). Definitions of time use variables can be found in Appendix Table B1. Time use variables are measured in hours per day. Partner working is a dummy variable that takes value " 1 " if respondent's partner works (part- or full-time), and value "0" otherwise. *Significant at the $90 \%$ level **Significant at the $95 \%$ level $* * *$ Significant at the $99 \%$ level. 


\section{Appendix A: Data Appendix}

We restrict our sample to individuals between the ages of 21 and 65 inclusive, providing 31,619 and 13,072 individuals for the 2002-03 and 2009-10 surveys, respectively. Additionally, to minimize the role of time allocation decisions that have a strong intertemporal component over the life cycle, such as education and retirement, we exclude retired individuals and students, providing 29,085 and 12,002 observations for the 200203 and 2009-10 surveys, and we finally select unemployed individuals, those individuals defining themselves as unemployed at the time of the survey, leaving 2,285 and 1,837 observations for the 2002-03 and 2009-10 surveys. Our final sample consists of 4,122 observations, with 1,884 men and 2,238 women observations. Our results can thus be interpreted as being 'per unemployed adult'. We exclude Ceuta and Melilla from the sample, given that there is no information on certain variables included in the empirical analysis, such as the Consumer Price Index and the Industrial Production Index.

Regarding the demographic composition of the sample of unemployed individuals, Table A1 shows the mean values of personal and household characteristics of the sample, by gender. We observe that men are older than women (37.42 and 35.05 years old for men and women, respectively), women have a higher level of education (13.6\% of men and $22.8 \%$ of women have university education), unemployed men have fewer children than the unemployed women in our sample, and a high proportion of individuals report having poor health $(54.1 \%$ and $53 \%$ of men and women, respectively). The proportion of individuals who have a household income of more then $3,000 €$ per month is slightly higher for the sample of unemployed men than for that of women. 
Table A1. Sum Stats for demographic characteristics, by gender

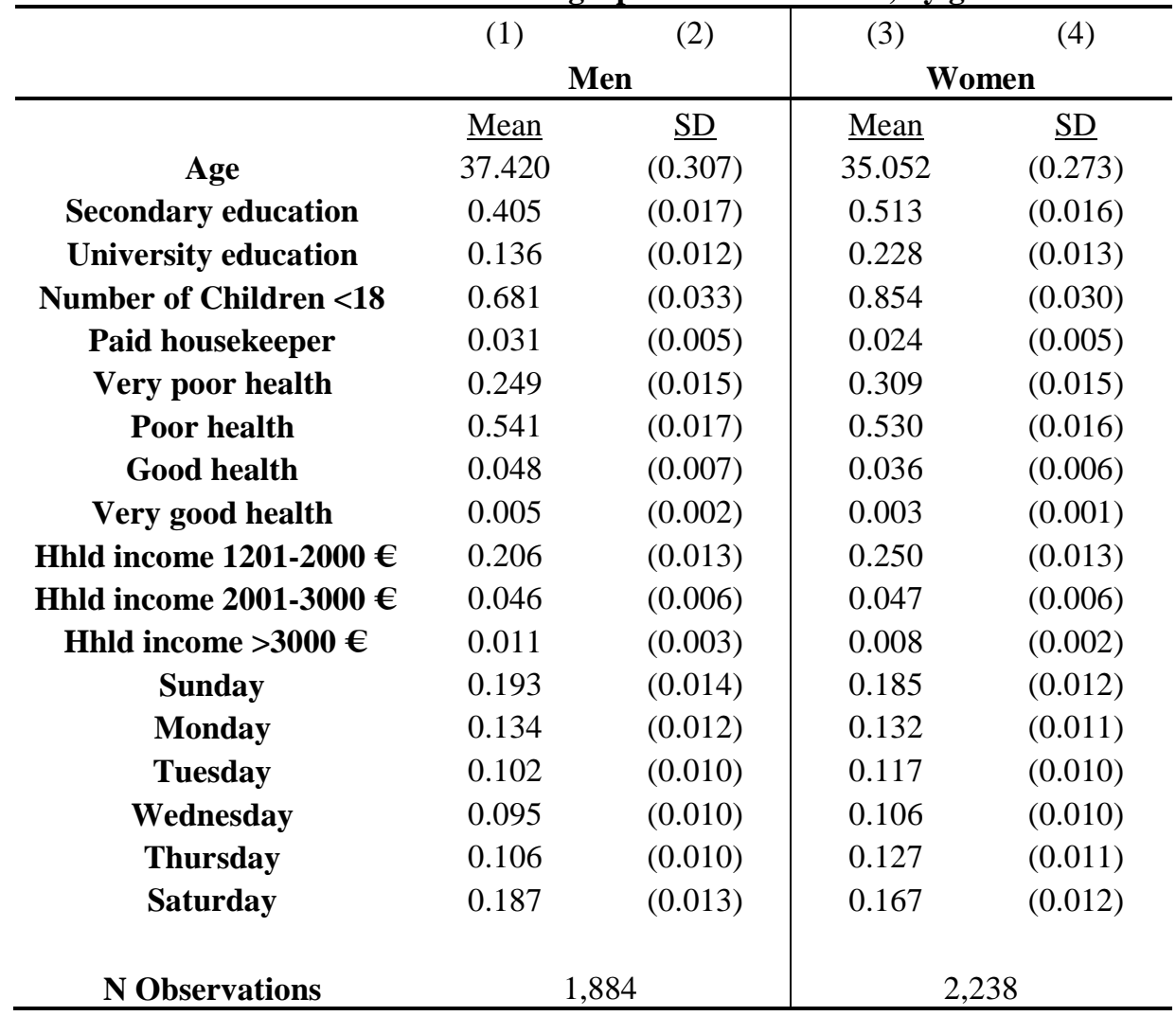

Notes: Standard deviations in parentheses. Sample consists of respondents aged 21-65 who are unemployed, from the Spanish Time Use Survey (STUS) 2002-2003 and 2009-2010. Regional Unemployment Rates comes from the Spanish Statistical Office (Instituto Nacional de Estadística), defined at the level of the 17 autonomous regions in Spain (Ceuta and Melilla are excluded from the analysis). Definitions of time use variables can be found in Appendix Table B1. Time use variables are measured in hours per day. 
Table A2. Unemployment rates in Spain, by region and gender

\begin{tabular}{|c|c|c|c|c|c|c|c|c|c|c|c|c|c|c|c|c|}
\hline & \multicolumn{8}{|c|}{ Men } & \multicolumn{8}{|c|}{ Women } \\
\hline & $\begin{array}{c}\text { 4th } \\
\text { term } \\
2002 \\
\end{array}$ & $\begin{array}{c}\text { 1st } \\
\text { term } \\
2002 \\
\end{array}$ & $\begin{array}{c}\text { 2nd } \\
\text { term } \\
2002 \\
\end{array}$ & $\begin{array}{c}\text { 3rd } \\
\text { term } \\
2003 \\
\end{array}$ & $\begin{array}{c}\text { 4th } \\
\text { term } \\
2009 \\
\end{array}$ & $\begin{array}{c}\text { 1st } \\
\text { term } \\
2010 \\
\end{array}$ & 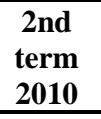 & $\begin{array}{c}\text { 3rd } \\
\text { term } \\
2010 \\
\end{array}$ & $\begin{array}{c}\text { 4th } \\
\text { term } \\
2002 \\
\end{array}$ & $\begin{array}{c}\text { 1st } \\
\text { term } \\
2002 \\
\end{array}$ & 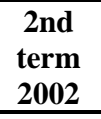 & $\begin{array}{c}\text { 3rd } \\
\text { term } \\
2003 \\
\end{array}$ & $\begin{array}{c}\text { 4th } \\
\text { term } \\
2009 \\
\end{array}$ & $\begin{array}{c}\text { 1st } \\
\text { term } \\
2001 \\
\end{array}$ & 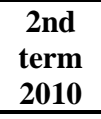 & $\begin{array}{c}\text { 3rd } \\
\text { term } \\
2010 \\
\end{array}$ \\
\hline Andalucia & 14.95 & 14.32 & 13.50 & 13.40 & 26.94 & 26.91 & 26.82 & 25.27 & 29.07 & 26.87 & 25.59 & 27.04 & 30.67 & 28.92 & 27.72 & 27.73 \\
\hline Aragon & 4.06 & 5.29 & 4.37 & 4.74 & 13.32 & 12.97 & 14.04 & 13.85 & 10.54 & 10.71 & 10.50 & 7.67 & 14 & 15.78 & 16.67 & 12.55 \\
\hline Asturias (Principado de) & 7.05 & 8.81 & 7.23 & 8.50 & 13.68 & 15.55 & 16.15 & 13.46 & 14.31 & 17.44 & 15.77 & 16.15 & 15.01 & 17.35 & 17.04 & 15.17 \\
\hline Balears (Illes) & 8.03 & 8.85 & 7.64 & 6.06 & 18.54 & 20.07 & 22.16 & 20.75 & 9.36 & 17.73 & 11.82 & 8.36 & 15.43 & 19.78 & 22.73 & 17.97 \\
\hline Canarias & 8.52 & 7.81 & 8.97 & 8.73 & 29.2 & 30.02 & 27.53 & 26.78 & 15.39 & 14.85 & 15.00 & 14.91 & 27.99 & 28.79 & 27.86 & 27.07 \\
\hline Cantabria & 8.55 & 7.05 & 7.21 & 7.55 & 11.84 & 12.64 & 12.95 & 12.12 & 14.09 & 15.16 & 15.46 & 16.79 & 12.59 & 15.49 & 16.47 & 13.27 \\
\hline Castilla y León & 6.33 & 6.98 & 6.16 & 6.54 & 13.26 & 13.92 & 14.72 & 12.36 & 16.32 & 17.99 & 19.09 & 17.70 & 17.66 & 19.44 & 17.38 & 16.54 \\
\hline Castilla-La Mancha & 5.67 & 6.68 & 5.82 & 5.63 & 17.19 & 19.6 & 19.73 & 17.41 & 17.20 & 17.92 & 17.40 & 16.92 & 23.38 & 23.95 & 24.29 & 21.89 \\
\hline Cataluña & 8.36 & 8.27 & 8.14 & 7.76 & 18.12 & 18.25 & 19.01 & 18.15 & 13.28 & 13.66 & 13.28 & 12.72 & 16.53 & 17.06 & 16.58 & 15.63 \\
\hline Comunidad Valenciana & 8.67 & 8.50 & 8.37 & 8.87 & 23.38 & 23.92 & 23.62 & 23.22 & 13.94 & 16.19 & 15.84 & 14.91 & 23.44 & 23.72 & 22.32 & 21.72 \\
\hline Extremadura & 14.59 & 14.74 & 12.06 & 10.95 & 19.66 & 19.76 & 20.8 & 17.46 & 26.57 & 28.09 & 23.95 & 24.53 & 26.28 & 26.21 & 27.12 & 26.64 \\
\hline Galicia & 8.06 & 8.62 & 7.98 & 8.25 & 14 & 14.71 & 14.58 & 11.87 & 17.33 & 18.64 & 17.14 & 18.13 & 15.88 & 16.6 & 16.5 & 14.07 \\
\hline Madrid (Comunidad de) & 4.55 & 5.13 & 5.01 & 5.58 & 15.29 & 16.35 & 16.36 & 14.58 & 10.34 & 11.32 & 9.83 & 10.04 & 16.74 & 16.51 & 15.96 & 14.79 \\
\hline Murcia (Región de) & 8.24 & 8.91 & 6.91 & 7.58 & 24.21 & 21.84 & 23.16 & 23.45 & 16.70 & 16.80 & 14.17 & 15.66 & 23.6 & 20.49 & 23.19 & 21.09 \\
\hline Navarra (Comunidad Foral de) & 3.39 & 3.27 & 3.88 & 4.34 & 10.56 & 10.5 & 13.4 & 9.83 & 8.38 & 9.05 & 7.63 & 7.84 & 14.88 & 11.52 & 10.95 & 11.41 \\
\hline País Vasco & 6.51 & 6.64 & 6.20 & 7.18 & 9.87 & 9.75 & 10.36 & 11.14 & 13.75 & 13.76 & 13.21 & 12.19 & 10.1 & 11.2 & 11.58 & 12.48 \\
\hline Rioja (La) & 3.86 & 3.33 & 2.81 & 3.69 & 13.04 & 10.56 & 13.32 & 13.02 & 9.00 & 11.94 & 9.10 & 9.07 & 15.22 & 14.32 & 17.77 & 14.52 \\
\hline
\end{tabular}

Source: Spanish Labor Force Survey (EPA), Instituto Nacional de Estadistica (2012). 
Table A3. Results for imputed income

\begin{tabular}{|c|c|}
\hline & Income \\
\hline Age & $\begin{array}{c}-0.023^{* * *} \\
(0.007)\end{array}$ \\
\hline Age squared & $\begin{array}{c}0.020^{* *} \\
(0.008)\end{array}$ \\
\hline Secondary education & $\begin{array}{c}0.032 \\
(0.024)\end{array}$ \\
\hline University education & $\begin{array}{c}0.244 * * * \\
(0.035)\end{array}$ \\
\hline Number of children & $\begin{array}{c}-0.033^{* *} \\
(0.015)\end{array}$ \\
\hline Paid housekeeping & $\begin{array}{c}0.819 * * * \\
(0.097)\end{array}$ \\
\hline Living in couple & $\begin{array}{c}0.153^{* * * *} \\
(0.021)\end{array}$ \\
\hline Living in urban area & $\begin{array}{l}0.038^{*} \\
(0.021)\end{array}$ \\
\hline Constant & $\begin{array}{c}1.845^{* * *} \\
(0.146)\end{array}$ \\
\hline Regional FE (Ref.: La Rioja) & Yes \\
\hline $\begin{array}{l}\text { N Observations } \\
\text { R-squared }\end{array}$ & $\begin{array}{r}3,867 \\
014\end{array}$ \\
\hline $\begin{array}{l}\text { Notes: Robust standard errors in } \\
\text { consists of respondents aged } 21-65 \\
\text { from the Spanish Time Use Surve } \\
\text { and 2009-2010. Regional FE are } \\
\text { control for region of residence, re } \\
\text { Rioja. Ceuta and Melilla are excluc } \\
\text { Bootstrapped robust standard e } \\
* \text { Significant at the } 90 \% \text { level } * * S \\
\text { level ***Significant }\end{array}$ & $\begin{array}{l}0.14 \\
\text { heses. San } \\
\text { re unemploy } \\
\text { JS) } 2002-2 \\
\text { y variables } \\
\text { region is } \\
m \text { the analy } \\
\text { are estima } \\
\text { nt at the }\end{array}$ \\
\hline
\end{tabular}


Table A4. Regional variables

\begin{tabular}{|c|c|c|c|c|c|c|c|c|c|c|c|}
\hline & $\begin{array}{l}\text { Consumer } \\
\text { price index }\end{array}$ & $\begin{array}{c}\text { Gross } \\
\text { domestic } \\
\text { product }\end{array}$ & $\begin{array}{l}\text { Activity rate of } \\
\text { the region }\end{array}$ & $\begin{array}{l}\text { Income per } \\
\text { capita }\end{array}$ & $\begin{array}{c}\text { Divorce } \\
\text { rates }\end{array}$ & $\begin{array}{c}\text { \% people } \\
\text { with very } \\
\text { poor health }\end{array}$ & $\begin{array}{c}\text { \% people } \\
\text { with poor } \\
\text { health } \\
\end{array}$ & $\begin{array}{c}\% \text { people } \\
\text { with good } \\
\text { health }\end{array}$ & $\begin{array}{c}\text { Share of } \\
\text { public jobs }\end{array}$ & $\begin{array}{c}\text { Industrial } \\
\text { production } \\
\text { index }\end{array}$ & $\begin{array}{c}\text { Industrial } \\
\text { price index }\end{array}$ \\
\hline \multirow[t]{2}{*}{ Andalucia } & 84.404 & 13.542 & 49.994 & 75.799 & 2.535 & 16.807 & 52.100 & 22.229 & 25.821 & 87.239 & 93.791 \\
\hline & $(0.209)$ & $(0.003)$ & (0.393) & (0.018) & (0.003) & $(0.167)$ & $(0.163)$ & $(0.102)$ & (0.101) & $(0.140)$ & (0.363) \\
\hline \multirow[t]{2}{*}{ Aragon } & 89.622 & 2.997 & 54.687 & 107.310 & 2.082 & 13.882 & 60.280 & 19.378 & 21.819 & 87.833 & 104.525 \\
\hline & $(0.840)$ & $(0.029)$ & $(1.165)$ & $(0.066)$ & $(0.023)$ & $(0.581)$ & $(0.821)$ & $(0.375)$ & $(0.454)$ & $(0.577)$ & $(0.833)$ \\
\hline \multirow[t]{2}{*}{ Asturias (Principado de) } & 88.804 & 2.232 & 47.978 & 90.205 & 2.838 & 11.583 & 52.118 & 25.895 & 23.381 & 92.452 & 104.603 \\
\hline & $(0.745)$ & $(0.015)$ & $(0.921)$ & $(0.454)$ & $(0.025)$ & $(0.321)$ & $(0.540)$ & $(0.330)$ & $(0.375)$ & $(0.520)$ & $(1.461)$ \\
\hline \multirow[t]{2}{*}{ Balears (Illes) } & 91.647 & 2.640 & 65.503 & 109.833 & 3.263 & 22.296 & 50.413 & 20.155 & 17.036 & 78.722 & 117.040 \\
\hline & $(0.797)$ & $(0.050)$ & $(0.918)$ & $(0.461)$ & $(0.080)$ & $(0.456)$ & $(0.190)$ & $(0.434)$ & $(0.155)$ & $(1.273)$ & $(1.739)$ \\
\hline \multirow[t]{2}{*}{ Canarias } & 91.154 & 3.717 & 59.705 & 89.361 & 3.472 & 11.085 & 56.489 & 23.452 & 21.516 & 89.646 & 108.270 \\
\hline & $(0.444)$ & $(0.056)$ & $(0.676)$ & $(0.271)$ & $(0.046)$ & $(0.185)$ & $(0.449)$ & $(0.174)$ & $(0.153)$ & $(0.418)$ & $(1.216)$ \\
\hline \multirow[t]{2}{*}{ Cantabria } & 89.728 & 1.735 & 51.482 & 99.418 & 2.563 & 11.548 & 59.478 & 21.682 & 24.110 & 92.614 & 105.729 \\
\hline & $(0.825)$ & $(0.146)$ & $(1.027)$ & $(0.266)$ & $(0.031)$ & $(0.212)$ & $(0.523)$ & $(0.375)$ & $(0.555)$ & $(0.320)$ & (1.526) \\
\hline \multirow[t]{2}{*}{ Castilla y León } & 87.669 & 5.008 & 50.308 & 95.476 & 1.734 & 14.719 & 58.319 & 20.860 & 26.466 & 88.536 & 104.663 \\
\hline & (0.618) & $(0.066)$ & $(0.884)$ & $(0.265)$ & $(0.015)$ & $(0.570)$ & $(0.553)$ & $(0.206)$ & $(0.440)$ & $(0.820)$ & $(0.775)$ \\
\hline \multirow[t]{2}{*}{ Castilla-La Mancha } & 88.988 & 4.325 & 51.236 & 77.541 & 1.825 & 16.743 & 50.160 & 25.880 & 27.994 & 86.422 & 103.200 \\
\hline & $(0.609)$ & $(0.294)$ & $(0.985)$ & $(0.098)$ & $(0.014)$ & $(0.485)$ & $(0.334)$ & $(0.203)$ & $(0.460)$ & $(0.296)$ & $(0.909)$ \\
\hline \multirow[t]{2}{*}{ Cataluña } & 85.111 & 17.457 & 58.498 & 119.398 & 3.335 & 19.408 & 50.771 & 22.076 & 15.056 & 95.243 & 101.101 \\
\hline & $(0.459)$ & $(0.174)$ & $(0.542)$ & $(0.090)$ & $(0.020)$ & $(0.202)$ & $(0.239)$ & $(0.157)$ & $(0.195)$ & $(0.395)$ & $(0.505)$ \\
\hline \multirow[t]{2}{*}{ Comunidad Valenciana } & 90.946 & 8.961 & 60.478 & 90.746 & 2.962 & 17.878 & 53.397 & 20.395 & 16.002 & 89.067 & 104.273 \\
\hline & $(0.467)$ & $(0.138)$ & $(0.633)$ & $(0.179)$ & $(0.028)$ & $(0.403)$ & $(0.687)$ & $(0.312)$ & $(0.177)$ & $(0.616)$ & $(0.757)$ \\
\hline \multirow[t]{2}{*}{ Extremadura } & 87.976 & 2.319 & 55.052 & 68.453 & 1.693 & 13.278 & 55.030 & 23.957 & 32.519 & 97.753 & 105.722 \\
\hline & $(0.597)$ & $(0.113)$ & $(0.965)$ & $(0.313)$ & $(0.016)$ & $(0.240)$ & $(0.404)$ & $(0.270)$ & $(0.766)$ & $(0.766)$ & (1.163) \\
\hline \multirow[t]{2}{*}{ Galicia } & 84.986 & 7.085 & 50.015 & 81.525 & 2.444 & 10.377 & 48.511 & 28.790 & 24.531 & 98.164 & 99.644 \\
\hline & $(0.396)$ & $(0.265)$ & $(0.486)$ & $(0.232)$ & $(0.012)$ & $(0.054)$ & $(0.240)$ & $(0.182)$ & $(0.257)$ & $(0.218)$ & $(0.581)$ \\
\hline \multirow[t]{2}{*}{ Madrid (Comunidad de) } & 88.995 & 15.274 & 60.511 & 131.242 & 2.717 & 20.456 & 52.729 & 20.466 & 19.741 & 91.061 & 105.334 \\
\hline & $(0.438)$ & $(0.324)$ & $(0.571)$ & $(0.071)$ & $(0.020)$ & $(0.350)$ & $(0.340)$ & $(0.167)$ & $(0.100)$ & $(0.271)$ & $(0.470)$ \\
\hline \multirow[t]{2}{*}{ Murcia (Región de) } & 88.914 & 2.498 & 61.634 & 82.652 & 2.494 & 16.248 & 54.550 & 21.356 & 18.775 & 83.561 & 105.588 \\
\hline & $(0.869)$ & $(0.022)$ & $(1.232)$ & $(0.195)$ & $(0.031)$ & $(0.208)$ & $(0.628)$ & $(0.481)$ & $(0.394)$ & $(0.252)$ & $(1.430)$ \\
\hline \multirow[t]{2}{*}{ Navarra (Comunidad Foral de) } & 90.015 & 2.288 & 57.261 & 127.996 & 2.033 & 19.974 & 53.393 & 19.589 & 18.081 & 90.047 & 109.630 \\
\hline & $(0.667)$ & $(0.132)$ & $(0.857)$ & $(0.179)$ & $(0.009)$ & $(0.363)$ & $(0.461)$ & $(0.162)$ & $(0.357)$ & $(0.416)$ & $(1.113)$ \\
\hline \multirow[t]{2}{*}{ País Vasco } & 88.713 & 5.539 & 53.313 & 129.787 & 2.155 & 16.041 & 56.554 & 20.752 & 20.042 & 89.559 & 102.103 \\
\hline & (0.777) & $(0.170)$ & $(0.802)$ & $(0.589)$ & $(0.020)$ & $(0.315)$ & $(0.368)$ & $(0.321)$ & $(0.435)$ & $(0.285)$ & (1.154) \\
\hline \multirow[t]{2}{*}{ Rioja (La) } & 90.354 & 0.657 & 56.846 & 109.046 & 2.114 & 15.163 & 63.347 & 16.385 & 18.332 & 90.396 & 109.264 \\
\hline & $(0.876)$ & $(0.024)$ & $(1.252)$ & $(0.101)$ & $(0.029)$ & $(0.554)$ & $(0.408)$ & $(0.427)$ & $(0.620)$ & $(1.060)$ & (1.213) \\
\hline
\end{tabular}

Source: Instituto Nacional de Estadistica (2012). 


\section{APPENDIX B: Definition of Time Use Variables}

Table B1. Definitions of time use categories

\begin{tabular}{|c|c|}
\hline Time Use Variables & Definitions \\
\hline Study & $\begin{array}{l}\text { main15 "regular schooling, education”; main16 “homework”; main17 “leisure/other } \\
\text { education or training”; main64 “education-related travel” }\end{array}$ \\
\hline Job Search & main14 “look for work” \\
\hline Household Production & $\begin{array}{l}\text { main18 “food preparation, cooking”; main19 “set table, wash/put away dishes”; main20 } \\
\text { “cleaning”; main21 “laundry, ironing, clothing”; main22 “home/vehicle } \\
\text { maintenance/improvement”; main23 “other domestic work”; main24 “purchase goods”; } \\
\text { main26 “consume other services”; main27 “pet care (other than walk dog)”; main28 } \\
\text { "physical, medical child care”; main29 “teach, help with homework”; main30 "read to, } \\
\text { talk or play with child”; main31 "supervise, accompany, other child care”; main32 “adult } \\
\text { care”; main66 “child/adult care-related travel”; main67 “travel for shopping, personal or } \\
\text { household care” }\end{array}$ \\
\hline Personal Care & $\begin{array}{l}\text { main1 “imputed personal or household care”; main2 “sleep and naps”; main3 “imputed } \\
\text { sleep”; main4 “wash, dress, care for self”; main5 “meals at work or school”; main6 } \\
\text { "other meals or snacks”; main25 “consume personal care services” }\end{array}$ \\
\hline Leisure & $\begin{array}{l}\text { main33 “voluntary work, civic, organization activity”; main34 “worship and religious } \\
\text { activity”; main35 “general out-of-home leisure”; main36 “attend sporting event”; main37 } \\
\text { “cinema, theatre, opera, concert”; main38 “other public event, venue”; main39 } \\
\text { “restaurant, café, bar, pub”; main40 “party, reception, social event, gambling”; main41 } \\
\text { “imputed time away from home”; main42 “general sport or exercise”; main43 “walking”; } \\
\text { main44 “cycling”; main45 “other out-of-doors recreation”; main46 “gardening/forage (eg } \\
\text { pick mushrooms), hunt/fish”; main47 “walk dogs”; main48 “receive or visit friends” } \\
\text { main49 “conversation (in person, phone)”; main50 “other in-home social, games”; } \\
\text { main51 “general indoor leisure”; main52 “artistic or musical activity”; main53 “written } \\
\text { correspondence”; main54 “knit, crafts or hobbies”; main55 “relax, think, do nothing”; } \\
\text { main56 “read”; main57 “listen to music, i-pod, CD, audio book”; main58 “listen to } \\
\text { radio”; main59 “watch TV, DVD, video”; main60 “play computer games”; main61 “send } \\
\text { e-mail, surf internet, computing”; main62 “no activity but mode of recorded travel”; } \\
\text { main65 “travel for voluntary/civic/religious activity”; main68 “travelling for other } \\
\text { purposes” }\end{array}$ \\
\hline
\end{tabular}


APPENDIX C: Additional Results

Table C1. Results using tobit models, men

\begin{tabular}{|c|c|c|c|c|c|}
\hline Men & $\begin{array}{c}\text { (1) } \\
\text { Study }\end{array}$ & $\begin{array}{c}(2) \\
\text { Job } \\
\text { Search }\end{array}$ & $\begin{array}{c}\text { (3) } \\
\text { Household } \\
\text { production }\end{array}$ & $\begin{array}{c}(4) \\
\text { Personal } \\
\text { Care }\end{array}$ & Leisure \\
\hline Regional unemployment Rates & $\begin{array}{c}1.436^{* * *} \\
(0.363)\end{array}$ & $\begin{array}{c}0.567 * * \\
(0.263)\end{array}$ & $\begin{array}{c}0.047 \\
(0.064)\end{array}$ & $\begin{array}{c}-0.069 * * \\
(0.028)\end{array}$ & $\begin{array}{c}-0.027 \\
(0.031)\end{array}$ \\
\hline Age & $\begin{array}{c}0.589 \\
(0.774)\end{array}$ & $\begin{array}{c}0.536 * * \\
(0.249)\end{array}$ & $\begin{array}{c}0.252^{* * *} \\
(0.028)\end{array}$ & $\begin{array}{l}-0.028 \\
(0.021)\end{array}$ & $\begin{array}{c}-0.114 \\
(0.078)\end{array}$ \\
\hline Age squared & $\begin{array}{l}-1.201 \\
(0.991)\end{array}$ & $\begin{array}{c}-0.917 * * * \\
(0.335)\end{array}$ & $\begin{array}{c}-0.250 * * * \\
(0.040)\end{array}$ & $\begin{array}{c}0.028 \\
(0.024)\end{array}$ & $\begin{array}{c}0.130 \\
(0.089)\end{array}$ \\
\hline Secondary education & $\begin{array}{c}3.756 \\
(2.588)\end{array}$ & $\begin{array}{l}-0.265 \\
(0.460)\end{array}$ & $\begin{array}{c}0.550 * * * \\
(0.185)\end{array}$ & $\begin{array}{c}-0.472 * * * \\
(0.063)\end{array}$ & $\begin{array}{l}-0.243 \\
(0.228)\end{array}$ \\
\hline University education & $\begin{array}{c}9.135 * * \\
(4.473)\end{array}$ & $\begin{array}{l}-0.161 \\
(0.525)\end{array}$ & $\begin{array}{c}0.811^{* * * *} \\
(0.183)\end{array}$ & $\begin{array}{c}-0.707^{* * *} \\
(0.186)\end{array}$ & $\begin{array}{c}-0.768 * * * \\
(0.120)\end{array}$ \\
\hline Number of children & $\begin{array}{l}-0.630 \\
(0.478)\end{array}$ & $\begin{array}{c}0.269 \\
(0.206)\end{array}$ & $\begin{array}{c}0.721^{* * * *} \\
(0.060)\end{array}$ & $\begin{array}{c}-0.119 * * * \\
(0.032)\end{array}$ & $\begin{array}{c}-0.522 * * * \\
(0.045)\end{array}$ \\
\hline Paid housekeeping & $\begin{array}{c}2.958 * * * \\
(0.779)\end{array}$ & $\begin{array}{l}-0.586 \\
(1.891)\end{array}$ & $\begin{array}{c}0.819 \\
(0.633)\end{array}$ & $\begin{array}{l}-0.399 \\
(0.484)\end{array}$ & $\begin{array}{l}-0.103 \\
(0.457)\end{array}$ \\
\hline Bad health & $\begin{array}{c}-0.119 \\
(1.435)\end{array}$ & $\begin{array}{l}-0.026 \\
(0.624)\end{array}$ & $\begin{array}{c}0.276 \\
(0.174)\end{array}$ & $\begin{array}{l}-0.039 \\
(0.271)\end{array}$ & $\begin{array}{l}-0.010 \\
(0.267)\end{array}$ \\
\hline Poor health & $\begin{array}{l}-0.189 \\
(2.077)\end{array}$ & $\begin{array}{c}0.381 \\
(0.515)\end{array}$ & $\begin{array}{c}0.197 \\
(0.230)\end{array}$ & $\begin{array}{c}0.081 \\
(0.260)\end{array}$ & $\begin{array}{c}0.034 \\
(0.197)\end{array}$ \\
\hline Good health & $\begin{array}{l}-1.785 \\
(3.170)\end{array}$ & $\begin{array}{c}-0.850 * * * \\
(0.327)\end{array}$ & $\begin{array}{c}0.177 \\
(0.279)\end{array}$ & $\begin{array}{c}0.789 * * * \\
(0.194)\end{array}$ & $\begin{array}{l}-0.457 * \\
(0.273)\end{array}$ \\
\hline Very good health & $\begin{array}{c}2.045 \\
(7.613)\end{array}$ & $\begin{array}{c}-222.220 \\
(0.000)\end{array}$ & $\begin{array}{l}-2.519 \\
(1.897)\end{array}$ & $\begin{array}{c}1.001 \\
(0.839)\end{array}$ & $\begin{array}{c}0.919 \\
(1.056)\end{array}$ \\
\hline Hhld income 1201-2000 $€$ & $\begin{array}{l}2.436 \\
(2.110)\end{array}$ & $\begin{array}{c}-2.752 * * * \\
(0.857)\end{array}$ & $\begin{array}{l}-0.017 \\
(0.274)\end{array}$ & $\begin{array}{c}-0.054 \\
(0.143)\end{array}$ & $\begin{array}{c}0.023 \\
(0.284)\end{array}$ \\
\hline Hhld income 2001-3000 $€$ & $\begin{array}{c}0.727 \\
(1.211)\end{array}$ & $\begin{array}{c}-0.559 \\
(0.760)\end{array}$ & $\begin{array}{c}-0.456 \\
(0.635)\end{array}$ & $\begin{array}{c}0.024 \\
(0.364)\end{array}$ & $\begin{array}{c}0.376 \\
(0.453)\end{array}$ \\
\hline Hhld income $>3000 €$ & $\begin{array}{l}-1.783 \\
(2.501)\end{array}$ & $\begin{array}{c}-0.741 \\
(1.183)\end{array}$ & $\begin{array}{c}-1.872 * * \\
(0.832)\end{array}$ & $\begin{array}{c}1.239 * * * \\
(0.254)\end{array}$ & $\begin{array}{l}0.380^{*} \\
(0.228)\end{array}$ \\
\hline Consumer price index & $\begin{array}{l}-0.235 \\
(0.437)\end{array}$ & $\begin{array}{c}0.267 \\
(0.248)\end{array}$ & $\begin{array}{c}0.042 \\
(0.046)\end{array}$ & $\begin{array}{c}0.004 \\
(0.024)\end{array}$ & $\begin{array}{l}-0.074 * \\
(0.043)\end{array}$ \\
\hline Gross domestic product & $\begin{array}{c}0.224 \\
(0.226)\end{array}$ & $\begin{array}{c}0.284 \\
(0.176)\end{array}$ & $\begin{array}{c}0.015 \\
(0.026)\end{array}$ & $\begin{array}{c}0.023^{* *} \\
(0.011)\end{array}$ & $\begin{array}{c}0.027 \\
(0.020)\end{array}$ \\
\hline Activity rate of the region & $\begin{array}{c}0.295 \\
(0.562)\end{array}$ & $\begin{array}{c}0.369 \\
(0.397)\end{array}$ & $\begin{array}{l}-0.033 \\
(0.035)\end{array}$ & $\begin{array}{l}0.048 * \\
(0.026)\end{array}$ & $\begin{array}{c}0.012 \\
(0.037)\end{array}$ \\
\hline Income per capita & $\begin{array}{c}0.204 \\
(0.145)\end{array}$ & $\begin{array}{c}0.083 \\
(0.099)\end{array}$ & $\begin{array}{c}0.012 \\
(0.012)\end{array}$ & $\begin{array}{c}-0.016^{* * *} \\
(0.005)\end{array}$ & $\begin{array}{c}-0.026^{* * *} \\
(0.008)\end{array}$ \\
\hline Divorce rates & $\begin{array}{l}-0.111 \\
(1.284)\end{array}$ & $\begin{array}{c}-0.338 \\
(1.247)\end{array}$ & $\begin{array}{c}0.196 \\
(0.147)\end{array}$ & $\begin{array}{l}-0.098 \\
(0.107)\end{array}$ & $\begin{array}{c}0.325 \\
(0.227)\end{array}$ \\
\hline$\%$ people in region with very poor health & $\begin{array}{c}0.682 \\
(1.075)\end{array}$ & $\begin{array}{c}0.308 \\
(0.705)\end{array}$ & $\begin{array}{l}-0.008 \\
(0.078)\end{array}$ & $\begin{array}{c}-0.098 * * \\
(0.043)\end{array}$ & $\begin{array}{l}-0.083 \\
(0.094)\end{array}$ \\
\hline$\%$ people in region with poor health & $\begin{array}{c}0.411 \\
(0.909)\end{array}$ & $\begin{array}{c}0.349 \\
(0.591)\end{array}$ & $\begin{array}{l}-0.050 \\
(0.067)\end{array}$ & $\begin{array}{c}-0.097 * * \\
(0.038)\end{array}$ & $\begin{array}{l}-0.027 \\
(0.079)\end{array}$ \\
\hline$\%$ people in region with good health & $\begin{array}{l}1.068 \\
(1.107)\end{array}$ & $\begin{array}{c}0.368 \\
(0.639)\end{array}$ & $\begin{array}{l}-0.079 \\
(0.066)\end{array}$ & $\begin{array}{c}-0.113^{* * *} \\
(0.036)\end{array}$ & $\begin{array}{l}-0.029 \\
(0.076)\end{array}$ \\
\hline Share of public jobs relative to private & $\begin{array}{l}0.470^{*} \\
(0.260)\end{array}$ & $\begin{array}{c}0.172 \\
(0.207)\end{array}$ & $\begin{array}{c}0.014 \\
(0.015)\end{array}$ & $\begin{array}{c}-0.031 * * * \\
(0.011)\end{array}$ & $\begin{array}{c}0.002 \\
(0.022)\end{array}$ \\
\hline Industrial production index & $\begin{array}{c}0.012 \\
(0.185)\end{array}$ & $\begin{array}{c}0.001 \\
(0.078)\end{array}$ & $\begin{array}{l}0.038 * * \\
(0.015)\end{array}$ & $\begin{array}{l}-0.011 \\
(0.013)\end{array}$ & $\begin{array}{c}0.007 \\
(0.018)\end{array}$ \\
\hline Industrial price index & $\begin{array}{c}-0.571^{* * * *} \\
(0.194)\end{array}$ & $\begin{array}{c}-0.462^{* * *} \\
(0.144)\end{array}$ & $\begin{array}{l}-0.017 \\
(0.023)\end{array}$ & $\begin{array}{c}0.017 \\
(0.011)\end{array}$ & $\begin{array}{l}0.069 * * \\
(0.028)\end{array}$ \\
\hline Constant & $\begin{array}{c}-68.546 \\
(111.355)\end{array}$ & $\begin{array}{l}-68.182 \\
(63.018)\end{array}$ & $\begin{array}{l}-5.358 \\
(8.161)\end{array}$ & $\begin{array}{c}20.713 * * * \\
(4.588)\end{array}$ & $\begin{array}{l}14.033^{*} \\
(7.867)\end{array}$ \\
\hline $\begin{array}{l}\text { N Observations } \\
\text { Pseudo R-squared }\end{array}$ & $\begin{array}{l}1,884 \\
0.225\end{array}$ & $\begin{array}{l}1,884 \\
0.178\end{array}$ & $\begin{array}{l}1,884 \\
0.026\end{array}$ & $\begin{array}{l}1,884 \\
0.014\end{array}$ & $\begin{array}{l}1,884 \\
0.014\end{array}$ \\
\hline
\end{tabular}

Notes: Robust standard errors in parentheses. Sample consists of respondents aged 21-65 who are unemployed, from the Spanish Time Use Survey (STUS) 2002-2003 and 2009-2010. Regional Unemployment Rates comes from the Spanish Statistical Office (Instituto Nacional de Estadística), defined at the level of the 17 autonomous regions in Spain (Ceuta and Melilla are excluded from the analysis). Definitions of time use variables can be found in Appendix Table B1. Time use variables are measured in hours per day. *Significant at the $90 \%$ level $* *$ Significant at the $95 \%$ level ***Significant at the $99 \%$ level. 
Table C2. Results using tobit models, women

\begin{tabular}{|c|c|c|c|c|c|}
\hline Women & $\begin{array}{c}\text { (1) } \\
\text { Study }\end{array}$ & $\begin{array}{c}(2) \\
\text { Job Search }\end{array}$ & $\begin{array}{c}(3) \\
\text { Household } \\
\text { production }\end{array}$ & $\begin{array}{c}(4) \\
\text { Personal } \\
\text { Care }\end{array}$ & Leisure \\
\hline Regional unemployment Rates & $\begin{array}{l}-0.105 \\
(0.141)\end{array}$ & $\begin{array}{c}-0.126 \\
(0.081)\end{array}$ & $\begin{array}{c}0.051^{* * *} \\
(0.017)\end{array}$ & $\begin{array}{l}0.048^{*} \\
(0.027)\end{array}$ & $\begin{array}{c}-0.106 * * * \\
(0.024)\end{array}$ \\
\hline Age & $\begin{array}{l}-0.216 \\
(0.141)\end{array}$ & $\begin{array}{c}0.086 \\
(0.254)\end{array}$ & $\begin{array}{c}0.434 * * * \\
(0.017)\end{array}$ & $\begin{array}{c}-0.115^{* * *} \\
(0.019)\end{array}$ & $\begin{array}{c}-0.230 * * * \\
(0.022)\end{array}$ \\
\hline Age squared & $\begin{array}{c}0.116 \\
(0.175)\end{array}$ & $\begin{array}{l}-0.287 \\
(0.346)\end{array}$ & $\begin{array}{c}-0.458 * * * \\
(0.022)\end{array}$ & $\begin{array}{c}0.100 * * * \\
(0.030)\end{array}$ & $\begin{array}{c}0.274 * * * \\
(0.031)\end{array}$ \\
\hline Secondary education & $\begin{array}{c}1.540 * * * \\
(0.401)\end{array}$ & $\begin{array}{c}1.491^{* *} \\
(0.596)\end{array}$ & $\begin{array}{c}-0.062 \\
(0.078)\end{array}$ & $\begin{array}{c}0.072 \\
(0.059)\end{array}$ & $\begin{array}{c}-0.042 \\
(0.073)\end{array}$ \\
\hline University education & $\begin{array}{c}5.521 * * * \\
(0.334)\end{array}$ & $\begin{array}{c}1.550 * * * \\
(0.555)\end{array}$ & $\begin{array}{c}-0.769 * * * \\
(0.111)\end{array}$ & $\begin{array}{l}-0.145 \\
(0.108)\end{array}$ & $\begin{array}{c}0.204 \\
(0.170)\end{array}$ \\
\hline Number of children & $\begin{array}{c}-1.559 * * * \\
(0.099)\end{array}$ & $\begin{array}{c}-1.818^{* * *} \\
(0.455)\end{array}$ & $\begin{array}{c}1.234^{* * *} \\
(0.109)\end{array}$ & $\begin{array}{c}-0.163^{* * *} \\
(0.025)\end{array}$ & $\begin{array}{c}-0.743 * * * \\
(0.083)\end{array}$ \\
\hline Paid housekeeping & $\begin{array}{l}-1.730 \\
(1.408)\end{array}$ & $\begin{array}{c}-5.977 * * * \\
(2.267)\end{array}$ & $\begin{array}{c}-0.568 \\
(0.528)\end{array}$ & $\begin{array}{c}-0.565 * * * \\
(0.176)\end{array}$ & $\begin{array}{c}1.502 * * * \\
(0.527)\end{array}$ \\
\hline Bad health & $\begin{array}{l}1.731^{*} \\
(1.022)\end{array}$ & $\begin{array}{c}-1.876 * * * \\
(0.435)\end{array}$ & $\begin{array}{l}-0.177 \\
(0.155)\end{array}$ & $\begin{array}{c}-0.403 * * * \\
(0.129)\end{array}$ & $\begin{array}{c}0.203 \\
(0.131)\end{array}$ \\
\hline Poor health & $\begin{array}{c}0.727 \\
(0.849)\end{array}$ & $\begin{array}{c}-1.237 * * * \\
(0.450)\end{array}$ & $\begin{array}{c}0.197 \\
(0.166)\end{array}$ & $\begin{array}{c}-0.417 * * * \\
(0.117)\end{array}$ & $\begin{array}{c}0.076 \\
(0.104)\end{array}$ \\
\hline Good health & $\begin{array}{c}-1.288 * * \\
(0.605)\end{array}$ & $\begin{array}{c}1.449 * * \\
(0.723)\end{array}$ & $\begin{array}{c}-0.875^{* * *} \\
(0.243)\end{array}$ & $\begin{array}{c}0.097 \\
(0.091)\end{array}$ & $\begin{array}{c}0.696 * * * \\
(0.188)\end{array}$ \\
\hline Very good health & $\begin{array}{c}0.930 \\
(4.763)\end{array}$ & $\begin{array}{l}-21.647 \\
(0.000)\end{array}$ & $\begin{array}{l}-1.110 \\
(0.709)\end{array}$ & $\begin{array}{c}3.034 * * * \\
(0.328)\end{array}$ & $\begin{array}{c}-2.046 * * * \\
(0.527)\end{array}$ \\
\hline Hhld income 1201-2000 $€$ & $\begin{array}{c}0.584 \\
(0.448)\end{array}$ & $\begin{array}{c}0.211 \\
(0.432)\end{array}$ & $\begin{array}{c}0.057 \\
(0.048)\end{array}$ & $\begin{array}{l}-0.069 \\
(0.100)\end{array}$ & $\begin{array}{l}-0.007 \\
(0.065)\end{array}$ \\
\hline Hhld income 2001-3000 € & $\begin{array}{c}-0.486 \\
(1.076)\end{array}$ & $\begin{array}{c}-4.098 * * \\
(1.772)\end{array}$ & $\begin{array}{c}0.079 \\
(0.311)\end{array}$ & $\begin{array}{c}0.284 \\
(0.219)\end{array}$ & $\begin{array}{l}-0.016 \\
(0.272)\end{array}$ \\
\hline Hhld income $>3000 €$ & $\begin{array}{c}-2.602 \\
(3.229)\end{array}$ & $\begin{array}{c}-0.061 \\
(1.834)\end{array}$ & $\begin{array}{c}0.128 \\
(0.947)\end{array}$ & $\begin{array}{c}1.615^{* *} \\
(0.726)\end{array}$ & $\begin{array}{c}-1.024 \\
(0.680)\end{array}$ \\
\hline Consumer price index & $\begin{array}{l}-0.304 \\
(0.210)\end{array}$ & $\begin{array}{c}0.015 \\
(0.114)\end{array}$ & $\begin{array}{c}0.059 \\
(0.041)\end{array}$ & $\begin{array}{l}0.059^{*} \\
(0.030)\end{array}$ & $\begin{array}{c}-0.055^{* * *} \\
(0.020)\end{array}$ \\
\hline Gross domestic product & $\begin{array}{c}0.084 \\
(0.056)\end{array}$ & $\begin{array}{c}0.049 \\
(0.037)\end{array}$ & $\begin{array}{l}-0.022 \\
(0.017)\end{array}$ & $\begin{array}{c}-0.033^{* * *} \\
(0.008)\end{array}$ & $\begin{array}{c}0.045^{* *} \\
(0.018)\end{array}$ \\
\hline Activity rate of the region & $\begin{array}{l}-0.025 \\
(0.313)\end{array}$ & $\begin{array}{c}0.486^{* *} \\
(0.224)\end{array}$ & $\begin{array}{l}-0.003 \\
(0.056)\end{array}$ & $\begin{array}{l}-0.057 \\
(0.048)\end{array}$ & $\begin{array}{l}-0.032 \\
(0.029)\end{array}$ \\
\hline Income per capita & $\begin{array}{l}-0.027 \\
(0.049)\end{array}$ & $\begin{array}{l}-0.039 \\
(0.039)\end{array}$ & $\begin{array}{c}0.018 \\
(0.012)\end{array}$ & $\begin{array}{c}0.012 \\
(0.012)\end{array}$ & $\begin{array}{c}-0.036 * * * \\
(0.012)\end{array}$ \\
\hline Divorce rates & $\begin{array}{c}0.565 \\
(0.644)\end{array}$ & $\begin{array}{c}-1.332 \\
(0.923)\end{array}$ & $\begin{array}{c}-0.084 \\
(0.164)\end{array}$ & $\begin{array}{l}-0.072 \\
(0.154)\end{array}$ & $\begin{array}{c}0.408^{*} \\
(0.208)\end{array}$ \\
\hline \% people in region with very poor health & $\begin{array}{c}-0.133 \\
(0.180)\end{array}$ & $\begin{array}{c}0.439 * * \\
(0.207)\end{array}$ & $\begin{array}{l}-0.051 \\
(0.058)\end{array}$ & $\begin{array}{c}0.014 \\
(0.055)\end{array}$ & $\begin{array}{c}0.095 \\
(0.067)\end{array}$ \\
\hline$\%$ people in region with poor health & $\begin{array}{l}-0.236 \\
(0.178)\end{array}$ & $\begin{array}{c}0.572 * * * \\
(0.211)\end{array}$ & $\begin{array}{l}-0.026 \\
(0.062)\end{array}$ & $\begin{array}{l}-0.009 \\
(0.061)\end{array}$ & $\begin{array}{c}0.088 \\
(0.066)\end{array}$ \\
\hline$\%$ people in region with good health & $\begin{array}{l}-0.361 \\
(0.305)\end{array}$ & $\begin{array}{c}0.994 * * * \\
(0.325)\end{array}$ & $\begin{array}{c}0.045 \\
(0.105)\end{array}$ & $\begin{array}{l}-0.009 \\
(0.093)\end{array}$ & $\begin{array}{c}0.029 \\
(0.103)\end{array}$ \\
\hline Share of public jobs relative to private & $\begin{array}{c}0.189 \\
(0.166)\end{array}$ & $\begin{array}{c}0.119 \\
(0.122)\end{array}$ & $\begin{array}{l}-0.031 \\
(0.022)\end{array}$ & $\begin{array}{c}-0.062^{* * *} \\
(0.017)\end{array}$ & $\begin{array}{l}0.027 \\
(0.024)\end{array}$ \\
\hline Industrial production index & $\begin{array}{l}-0.088 \\
(0.131)\end{array}$ & $\begin{array}{l}-0.093 \\
(0.073)\end{array}$ & $\begin{array}{c}0.025 \\
(0.017)\end{array}$ & $\begin{array}{c}0.017 \\
(0.018)\end{array}$ & $\begin{array}{l}-0.014 \\
(0.019)\end{array}$ \\
\hline Industrial price index & $\begin{array}{c}0.231 * * * \\
(0.050)\end{array}$ & $\begin{array}{c}-0.129 * * * \\
(0.045)\end{array}$ & $\begin{array}{c}-0.065^{* * *} \\
(0.014)\end{array}$ & $\begin{array}{l}-0.008 \\
(0.011)\end{array}$ & $\begin{array}{c}0.067 * * * \\
(0.014)\end{array}$ \\
\hline Constant & $\begin{array}{c}29.123 \\
(25.731)\end{array}$ & $\begin{array}{c}-60.699 * * * \\
(22.179)\end{array}$ & $\begin{array}{l}-4.825 \\
(5.610)\end{array}$ & $\begin{array}{c}11.256^{* *} \\
(5.299)\end{array}$ & $\begin{array}{c}8.090 \\
(6.951)\end{array}$ \\
\hline $\begin{array}{c}\text { N Observations } \\
\text { Pseudo R-squared }\end{array}$ & $\begin{array}{l}2,238 \\
0.076\end{array}$ & $\begin{array}{l}2,238 \\
0.131\end{array}$ & $\begin{array}{l}2,238 \\
0.074\end{array}$ & $\begin{array}{l}2,238 \\
0.033\end{array}$ & $\begin{array}{l}2,238 \\
0.034\end{array}$ \\
\hline
\end{tabular}

Notes: Robust standard errors in parentheses. Sample consists of respondents aged 21-65 who are unemployed, from the Spanish Time Use Survey (STUS) 2002-2003 and 2009-2010. Regional Unemployment Rates comes from the Spanish Statistical Office (Instituto Nacional de Estadística), defined at the level of the 17 autonomous regions in Spain (Ceuta and Melilla are excluded from the analysis). Definitions of time use variables can be found in Appendix Table B1. Time use variables are measured in hours per day. *Significant at the $90 \%$ level **Significant at the $95 \%$ level ***Significant at the $99 \%$ level. 
Table C3. Results including urban status, men

\begin{tabular}{|c|c|c|c|c|c|}
\hline Men & $\begin{array}{c}\text { (1) } \\
\text { Study } \\
\end{array}$ & $\begin{array}{c}(2) \\
\text { Job } \\
\text { Search } \\
\end{array}$ & $\begin{array}{l}\text { (3) } \\
\text { Household } \\
\text { production }\end{array}$ & $\begin{array}{c}(4) \\
\text { Personal } \\
\text { Care } \\
\end{array}$ & Leisure \\
\hline Age & $\begin{array}{l}-0.030 \\
(0.025)\end{array}$ & $\begin{array}{l}-0.013 \\
(0.016)\end{array}$ & $\begin{array}{c}0.177 * * * \\
(0.036)\end{array}$ & $\begin{array}{l}-0.033 \\
(0.021)\end{array}$ & $\begin{array}{l}-0.114 \\
(0.079)\end{array}$ \\
\hline Age squared & $\begin{array}{c}0.022 \\
(0.029)\end{array}$ & $\begin{array}{c}-0.001 \\
(0.012)\end{array}$ & $\begin{array}{c}-0.166^{* * *} \\
(0.049)\end{array}$ & $\begin{array}{c}0.033 \\
(0.024)\end{array}$ & $\begin{array}{c}0.130 \\
(0.090)\end{array}$ \\
\hline Secondary education & $\begin{array}{c}0.214^{* * *} \\
(0.052)\end{array}$ & $\begin{array}{c}-0.085^{* *} \\
(0.039)\end{array}$ & $\begin{array}{c}0.506^{* * * *} \\
(0.143)\end{array}$ & $\begin{array}{c}-0.415^{* * *} \\
(0.062)\end{array}$ & $\begin{array}{c}-0.246 \\
(0.220)\end{array}$ \\
\hline University education & $\begin{array}{c}1.089 * * * \\
(0.165)\end{array}$ & $\begin{array}{l}-0.154^{*} \\
(0.083)\end{array}$ & $\begin{array}{c}0.631^{* * *} \\
(0.164)\end{array}$ & $\begin{array}{c}-0.602 * * * \\
(0.151)\end{array}$ & $\begin{array}{c}-0.760 * * * \\
(0.137)\end{array}$ \\
\hline Number of children & $\begin{array}{c}-0.073 * * * \\
(0.013)\end{array}$ & $\begin{array}{c}0.039 \\
(0.028)\end{array}$ & $\begin{array}{c}0.653 * * * \\
(0.051)\end{array}$ & $\begin{array}{c}-0.117 * * * \\
(0.033)\end{array}$ & $\begin{array}{c}-0.523 * * * \\
(0.045)\end{array}$ \\
\hline Paid housekeeping & $\begin{array}{c}0.029 \\
(0.137)\end{array}$ & $\begin{array}{l}-0.052 \\
(0.152)\end{array}$ & $\begin{array}{c}0.635 \\
(0.382)\end{array}$ & $\begin{array}{l}-0.425 \\
(0.493)\end{array}$ & $\begin{array}{l}-0.110 \\
(0.483)\end{array}$ \\
\hline Bad health & $\begin{array}{c}0.128 \\
(0.121)\end{array}$ & $\begin{array}{c}-0.054 \\
(0.089)\end{array}$ & $\begin{array}{c}0.202 \\
(0.127)\end{array}$ & $\begin{array}{l}-0.068 \\
(0.256)\end{array}$ & $\begin{array}{l}-0.017 \\
(0.261)\end{array}$ \\
\hline Poor health & $\begin{array}{l}-0.030 \\
(0.120)\end{array}$ & $\begin{array}{c}-0.010 \\
(0.100)\end{array}$ & $\begin{array}{c}0.191 \\
(0.178)\end{array}$ & $\begin{array}{c}0.085 \\
(0.260)\end{array}$ & $\begin{array}{c}0.032 \\
(0.200)\end{array}$ \\
\hline Good health & $\begin{array}{c}-0.197 * * \\
(0.070)\end{array}$ & $\begin{array}{c}0.009 \\
(0.032)\end{array}$ & $\begin{array}{c}0.197 \\
(0.271)\end{array}$ & $\begin{array}{c}0.748 * * * \\
(0.194)\end{array}$ & $\begin{array}{c}-0.451 \\
(0.273)\end{array}$ \\
\hline Very good health & $\begin{array}{c}0.267 \\
(0.395)\end{array}$ & $\begin{array}{c}-0.479 * * * \\
(0.076)\end{array}$ & $\begin{array}{l}-1.325 \\
(0.818)\end{array}$ & $\begin{array}{c}1.054 \\
(0.897)\end{array}$ & $\begin{array}{c}0.896 \\
(1.059)\end{array}$ \\
\hline Hhld income 1201-2000 € & $\begin{array}{c}0.419 * * * \\
(0.102)\end{array}$ & $\begin{array}{c}-0.385 * * * \\
(0.061)\end{array}$ & $\begin{array}{c}-0.004 \\
(0.187)\end{array}$ & $\begin{array}{c}-0.034 \\
(0.134)\end{array}$ & $\begin{array}{c}0.025 \\
(0.281)\end{array}$ \\
\hline Hhld income 2001-3000€ & $\begin{array}{l}-0.003 \\
(0.158)\end{array}$ & $\begin{array}{l}-0.081 \\
(0.062)\end{array}$ & $\begin{array}{l}-0.357 \\
(0.398)\end{array}$ & $\begin{array}{c}0.063 \\
(0.380)\end{array}$ & $\begin{array}{c}0.381 \\
(0.453)\end{array}$ \\
\hline Hhld income $>3000 €$ & $\begin{array}{c}0.110 \\
(0.473)\end{array}$ & $\begin{array}{l}-0.138 \\
(0.124)\end{array}$ & $\begin{array}{c}-1.607 * * * \\
(0.435)\end{array}$ & $\begin{array}{c}1.292 * * * \\
(0.346)\end{array}$ & $\begin{array}{c}0.369 \\
(0.229)\end{array}$ \\
\hline Consumer price index & $\begin{array}{c}-0.017 \\
(0.019)\end{array}$ & $\begin{array}{c}0.026 * * \\
(0.011)\end{array}$ & $\begin{array}{c}0.032 \\
(0.033)\end{array}$ & $\begin{array}{c}0.007 \\
(0.026)\end{array}$ & $\begin{array}{l}-0.076^{*} \\
(0.042)\end{array}$ \\
\hline Gross domestic product & $\begin{array}{c}-0.026 * * \\
(0.011)\end{array}$ & $\begin{array}{c}-0.012 \\
(0.011)\end{array}$ & $\begin{array}{l}-0.008 \\
(0.023)\end{array}$ & $\begin{array}{c}0.024^{* *} \\
(0.011)\end{array}$ & $\begin{array}{c}0.028 \\
(0.021)\end{array}$ \\
\hline Activity rate of the region & $\begin{array}{c}-0.014 \\
(0.012)\end{array}$ & $\begin{array}{c}0.006 \\
(0.014)\end{array}$ & $\begin{array}{l}-0.023 \\
(0.017)\end{array}$ & $\begin{array}{c}0.044^{* *} \\
(0.019)\end{array}$ & $\begin{array}{c}0.001 \\
(0.037)\end{array}$ \\
\hline Income per capita & $\begin{array}{c}0.012 * * \\
(0.005)\end{array}$ & $\begin{array}{c}0.013^{* *} \\
(0.006)\end{array}$ & $\begin{array}{c}0.006 \\
(0.009)\end{array}$ & $\begin{array}{c}-0.011 * * \\
(0.005)\end{array}$ & $\begin{array}{c}-0.025^{* * *} \\
(0.007)\end{array}$ \\
\hline Divorce rates & $\begin{array}{c}-0.032 \\
(0.097)\end{array}$ & $\begin{array}{c}-0.229 * * \\
(0.099)\end{array}$ & $\begin{array}{c}0.125 \\
(0.113)\end{array}$ & $\begin{array}{l}-0.123 \\
(0.108)\end{array}$ & $\begin{array}{c}0.347 \\
(0.239)\end{array}$ \\
\hline$\%$ people in region with very poor health & $\begin{array}{c}0.071 \\
(0.055)\end{array}$ & $\begin{array}{l}0.046 * \\
(0.026)\end{array}$ & $\begin{array}{c}0.037 \\
(0.074)\end{array}$ & $\begin{array}{c}-0.122 * * \\
(0.048)\end{array}$ & $\begin{array}{l}-0.087 \\
(0.101)\end{array}$ \\
\hline$\%$ people in region with poor health & $\begin{array}{c}0.051 \\
(0.047)\end{array}$ & $\begin{array}{l}0.043^{*} \\
(0.022)\end{array}$ & $\begin{array}{c}-0.011 \\
(0.062)\end{array}$ & $\begin{array}{c}-0.115^{* *} \\
(0.043)\end{array}$ & $\begin{array}{c}-0.030 \\
(0.083)\end{array}$ \\
\hline$\%$ people in region with good health & $\begin{array}{l}0.080^{*} \\
(0.044)\end{array}$ & $\begin{array}{c}0.050^{* *} \\
(0.022)\end{array}$ & $\begin{array}{c}-0.034 \\
(0.067)\end{array}$ & $\begin{array}{c}-0.129 * * * \\
(0.040)\end{array}$ & $\begin{array}{c}-0.034 \\
(0.083)\end{array}$ \\
\hline Share of public jobs relative to private & $\begin{array}{c}0.020 * * * \\
(0.006)\end{array}$ & $\begin{array}{c}0.008 \\
(0.009)\end{array}$ & $\begin{array}{c}0.009 \\
(0.009)\end{array}$ & $\begin{array}{c}-0.031 * * * \\
(0.010)\end{array}$ & $\begin{array}{c}0.003 \\
(0.021)\end{array}$ \\
\hline Industrial production index & $\begin{array}{l}-0.001 \\
(0.008)\end{array}$ & $\begin{array}{l}-0.007 \\
(0.005)\end{array}$ & $\begin{array}{l}0.030^{* *} \\
(0.010)\end{array}$ & $\begin{array}{l}-0.016 \\
(0.013)\end{array}$ & $\begin{array}{c}0.006 \\
(0.018)\end{array}$ \\
\hline Industrial price index & $\begin{array}{c}-0.021^{* * *} \\
(0.006)\end{array}$ & $\begin{array}{c}-0.038 * * \\
(0.014)\end{array}$ & $\begin{array}{c}0.002 \\
(0.015)\end{array}$ & $\begin{array}{c}0.011 \\
(0.011)\end{array}$ & $\begin{array}{c}0.070 * * \\
(0.027)\end{array}$ \\
\hline Constant & $\begin{array}{l}-2.101 \\
(5.343)\end{array}$ & $\begin{array}{l}-2.516 \\
(2.533)\end{array}$ & $\begin{array}{l}-6.158 \\
(7.004)\end{array}$ & $\begin{array}{l}23.072 * * * \\
(5.208)\end{array}$ & $\begin{array}{l}15.190 * \\
(8.102)\end{array}$ \\
\hline $\begin{array}{c}\text { N Observations } \\
\text { Pseudo R-squared }\end{array}$ & $\begin{array}{l}1,884 \\
0.112\end{array}$ & $\begin{array}{l}1,884 \\
0.080\end{array}$ & $\begin{array}{l}1,884 \\
0.131\end{array}$ & $\begin{array}{l}1,884 \\
0.078\end{array}$ & $\begin{array}{l}1,884 \\
0.092\end{array}$ \\
\hline
\end{tabular}

Notes: Robust standard errors in parentheses. Sample consists of respondents aged 21-65 who are unemployed, from the Spanish Time Use Survey (STUS) 2002-2003 and 2009-2010. Regional Unemployment Rates comes from the Spanish Statistical Office (Instituto Nacional de Estadística), defined at the level of the 17 autonomous regions in Spain (Ceuta and Melilla are excluded from the analysis). Definitions of time use variables can be found in Appendix Table B1. Time use variables are measured in hours per day. Urban area is a dummy variable that takes value " 1 " if the respondent lives in an urban area, and " 0 - otherwise. We use the aggregation level of the Multinational Time Use Study version of the STUS, which considers that the individual lives in an urban area if the city has 50,000 inhabitants or more, and in a rural area if there are less than 50,000 inhabitants. *Significant at the $90 \%$ level $* *$ Significant at the $95 \%$ level $* * *$ Significant at the $99 \%$ level. 
Table C4. Results including urban status, women

\begin{tabular}{|c|c|c|c|c|c|}
\hline Women & Study & $\begin{array}{c}(2) \\
\text { Job } \\
\text { Search }\end{array}$ & $\begin{array}{c}\text { (3) } \\
\text { Household } \\
\text { production }\end{array}$ & $\begin{array}{c}(4) \\
\text { Personal } \\
\text { Care }\end{array}$ & Leisure \\
\hline Age & $\begin{array}{c}-0.071 * * * \\
(0.020)\end{array}$ & $\begin{array}{c}0.003 \\
(0.010)\end{array}$ & $\begin{array}{c}0.413^{* * *} \\
(0.018)\end{array}$ & $\begin{array}{c}-0.114^{* * *} \\
(0.019)\end{array}$ & $\begin{array}{c}-0.226 * * * \\
(0.023)\end{array}$ \\
\hline Age squared & $\begin{array}{c}0.069 * * \\
(0.026)\end{array}$ & $\begin{array}{l}-0.010 \\
(0.014)\end{array}$ & $\begin{array}{c}-0.435 * * * \\
(0.024)\end{array}$ & $\begin{array}{c}0.099 * * * \\
(0.031)\end{array}$ & $\begin{array}{c}0.269 * * * \\
(0.031)\end{array}$ \\
\hline Secondary education & $\begin{array}{c}0.095 \\
(0.068)\end{array}$ & $\begin{array}{c}0.008 \\
(0.019)\end{array}$ & $\begin{array}{l}-0.039 \\
(0.079)\end{array}$ & $\begin{array}{c}0.078 \\
(0.061)\end{array}$ & $\begin{array}{l}-0.012 \\
(0.081)\end{array}$ \\
\hline University education & $\begin{array}{c}0.822 * * * \\
(0.057)\end{array}$ & $\begin{array}{l}-0.040 \\
(0.028)\end{array}$ & $\begin{array}{c}-0.740 * * * \\
(0.113)\end{array}$ & $\begin{array}{c}-0.134 \\
(0.107)\end{array}$ & $\begin{array}{c}0.239 \\
(0.199)\end{array}$ \\
\hline Number of children & $\begin{array}{c}-0.182^{* * * *} \\
(0.007)\end{array}$ & $\begin{array}{c}-0.068 * * * \\
(0.015)\end{array}$ & $\begin{array}{c}1.224 * * * \\
(0.101)\end{array}$ & $\begin{array}{c}-0.165^{* * * *} \\
(0.024)\end{array}$ & $\begin{array}{c}-0.742 * * * \\
(0.083)\end{array}$ \\
\hline Paid housekeeping & $\begin{array}{c}-0.417 * * * \\
(0.137)\end{array}$ & $\begin{array}{c}-0.125^{* * *} \\
(0.042)\end{array}$ & $\begin{array}{c}-0.592 \\
(0.540)\end{array}$ & $\begin{array}{c}-0.549 * * * \\
(0.170)\end{array}$ & $\begin{array}{c}1.537 * * \\
(0.555)\end{array}$ \\
\hline Bad health & $\begin{array}{c}0.380 * * \\
(0.137)\end{array}$ & $\begin{array}{c}-0.109 * * \\
(0.044)\end{array}$ & $\begin{array}{l}-0.191 \\
(0.157)\end{array}$ & $\begin{array}{c}-0.404 * * * \\
(0.130)\end{array}$ & $\begin{array}{c}0.208 \\
(0.126)\end{array}$ \\
\hline Poor health & $\begin{array}{c}0.123 \\
(0.078)\end{array}$ & $\begin{array}{c}-0.060 \\
(0.050)\end{array}$ & $\begin{array}{c}0.167 \\
(0.165)\end{array}$ & $\begin{array}{c}-0.420 * * * \\
(0.119)\end{array}$ & $\begin{array}{c}0.075 \\
(0.107)\end{array}$ \\
\hline Good health & $\begin{array}{l}-0.058 \\
(0.044)\end{array}$ & $\begin{array}{c}0.001 \\
(0.038)\end{array}$ & $\begin{array}{c}-0.889 * * * \\
(0.255)\end{array}$ & $\begin{array}{c}0.079 \\
(0.090)\end{array}$ & $\begin{array}{c}0.722 * * * \\
(0.191)\end{array}$ \\
\hline Very good health & $\begin{array}{c}0.323 \\
(0.706)\end{array}$ & $\begin{array}{c}-0.195 * * * \\
(0.046)\end{array}$ & $\begin{array}{l}-1.038 \\
(0.647)\end{array}$ & $\begin{array}{c}3.039 * * * \\
(0.333)\end{array}$ & $\begin{array}{c}-2.025 * * * \\
(0.518)\end{array}$ \\
\hline Hhld income 1201-2000 $€$ & $\begin{array}{l}-0.042 \\
(0.073)\end{array}$ & $\begin{array}{c}0.029 * * \\
(0.013)\end{array}$ & $\begin{array}{c}0.043 \\
(0.039)\end{array}$ & $\begin{array}{c}-0.064 \\
(0.099)\end{array}$ & $\begin{array}{c}-0.001 \\
(0.067)\end{array}$ \\
\hline Hhld income 2001-3000 $€$ & $\begin{array}{l}-0.261 \\
(0.195)\end{array}$ & $\begin{array}{c}-0.108 * * \\
(0.041)\end{array}$ & $\begin{array}{c}0.069 \\
(0.296)\end{array}$ & $\begin{array}{c}0.295 \\
(0.225)\end{array}$ & $\begin{array}{c}0.007 \\
(0.281)\end{array}$ \\
\hline Hhld income $>3000 €$ & $\begin{array}{l}-0.584 * \\
(0.322)\end{array}$ & $\begin{array}{l}-0.023 \\
(0.052)\end{array}$ & $\begin{array}{c}0.042 \\
(0.964)\end{array}$ & $\begin{array}{l}1.617^{* *} \\
(0.732)\end{array}$ & $\begin{array}{l}-1.023 \\
(0.691)\end{array}$ \\
\hline Consumer price index & $\begin{array}{l}-0.041 \\
(0.033)\end{array}$ & $\begin{array}{c}0.007 \\
(0.007)\end{array}$ & $\begin{array}{c}0.053 \\
(0.039)\end{array}$ & $\begin{array}{l}0.058^{*} \\
(0.030)\end{array}$ & $\begin{array}{c}-0.055 * * * \\
(0.018)\end{array}$ \\
\hline Gross domestic product & $\begin{array}{l}0.015^{*} \\
(0.007)\end{array}$ & $\begin{array}{c}0.001 \\
(0.005)\end{array}$ & $\begin{array}{l}-0.022 \\
(0.017)\end{array}$ & $\begin{array}{c}-0.033^{* * *} \\
(0.008)\end{array}$ & $\begin{array}{c}0.044 * * \\
(0.018)\end{array}$ \\
\hline Activity rate of the region & $\begin{array}{c}0.019 \\
(0.049)\end{array}$ & $\begin{array}{l}0.033^{*} \\
(0.017)\end{array}$ & $\begin{array}{c}0.006 \\
(0.052)\end{array}$ & $\begin{array}{l}-0.058 \\
(0.049)\end{array}$ & $\begin{array}{l}-0.039 \\
(0.029)\end{array}$ \\
\hline Income per capita & $\begin{array}{l}-0.003 \\
(0.007)\end{array}$ & $\begin{array}{l}-0.001 \\
(0.003)\end{array}$ & $\begin{array}{l}0.021^{*} \\
(0.011)\end{array}$ & $\begin{array}{c}0.012 \\
(0.011)\end{array}$ & $\begin{array}{c}-0.036 * * * \\
(0.012)\end{array}$ \\
\hline Divorce rates & $\begin{array}{l}-0.074 \\
(0.101)\end{array}$ & $\begin{array}{l}-0.126^{*} \\
(0.063)\end{array}$ & $\begin{array}{l}-0.113 \\
(0.163)\end{array}$ & $\begin{array}{l}-0.071 \\
(0.155)\end{array}$ & $\begin{array}{l}0.404^{*} \\
(0.213)\end{array}$ \\
\hline$\%$ people in region with very poor health & $\begin{array}{l}-0.019 \\
(0.025)\end{array}$ & $\begin{array}{c}0.007 \\
(0.012)\end{array}$ & $\begin{array}{l}-0.050 \\
(0.057)\end{array}$ & $\begin{array}{c}0.014 \\
(0.056)\end{array}$ & $\begin{array}{c}0.091 \\
(0.065)\end{array}$ \\
\hline$\%$ people in region with poor health & $\begin{array}{l}-0.029 \\
(0.025)\end{array}$ & $\begin{array}{c}0.012 \\
(0.014)\end{array}$ & $\begin{array}{l}-0.025 \\
(0.060)\end{array}$ & $\begin{array}{l}-0.009 \\
(0.062)\end{array}$ & $\begin{array}{c}0.082 \\
(0.063)\end{array}$ \\
\hline$\%$ people in region with good health & $\begin{array}{l}-0.051 \\
(0.041)\end{array}$ & $\begin{array}{c}0.022 \\
(0.019)\end{array}$ & $\begin{array}{c}0.048 \\
(0.103)\end{array}$ & $\begin{array}{l}-0.010 \\
(0.095)\end{array}$ & $\begin{array}{c}0.023 \\
(0.099)\end{array}$ \\
\hline Share of public jobs relative to private & $\begin{array}{c}0.031 \\
(0.024)\end{array}$ & $\begin{array}{c}0.007 \\
(0.006)\end{array}$ & $\begin{array}{l}-0.022 \\
(0.021)\end{array}$ & $\begin{array}{c}-0.064 * * * \\
(0.018)\end{array}$ & $\begin{array}{l}0.018 \\
(0.023)\end{array}$ \\
\hline Industrial production index & $\begin{array}{l}-0.015 \\
(0.022)\end{array}$ & $\begin{array}{l}-0.002 \\
(0.003)\end{array}$ & $\begin{array}{c}0.017 \\
(0.018)\end{array}$ & $\begin{array}{c}0.018 \\
(0.019)\end{array}$ & $\begin{array}{l}-0.011 \\
(0.019)\end{array}$ \\
\hline Industrial price index & $\begin{array}{c}0.024^{* * *} \\
(0.006)\end{array}$ & $\begin{array}{c}-0.015^{* * *} \\
(0.004)\end{array}$ & $\begin{array}{c}-0.066^{* * *} \\
(0.014)\end{array}$ & $\begin{array}{l}-0.007 \\
(0.012)\end{array}$ & $\begin{array}{c}0.069 * * * \\
(0.014)\end{array}$ \\
\hline Constant & $\begin{array}{c}6.660 \\
(4.518)\end{array}$ & $\begin{array}{l}-1.157 \\
(1.340)\end{array}$ & $\begin{array}{l}-3.550 \\
(5.676)\end{array}$ & $\begin{array}{l}11.149 * \\
(5.404)\end{array}$ & $\begin{array}{l}7.941 \\
(6.804)\end{array}$ \\
\hline $\begin{array}{l}\text { N Observations } \\
\text { Pseudo R-squared }\end{array}$ & $\begin{array}{l}2,238 \\
0.102\end{array}$ & $\begin{array}{l}2,238 \\
0.043\end{array}$ & $\begin{array}{l}2,238 \\
0.326\end{array}$ & $\begin{array}{l}2,238 \\
0.134\end{array}$ & $\begin{array}{l}2,238 \\
0.161\end{array}$ \\
\hline
\end{tabular}

Notes: Robust standard errors in parentheses. Sample consists of respondents aged 21-65 who are unemployed, from the Spanish Time Use Survey (STUS) 2002-2003 and 2009-2010. Regional Unemployment Rates comes from the Spanish Statistical Office (Instituto Nacional de Estadística), defined at the level of the 17 autonomous regions in Spain (Ceuta and Melilla are excluded from the analysis). Definitions of time use variables can be found in Appendix Table B1. Time use variables are measured in hours per day. Urban area is a dummy variable that takes value " 1 " if the respondent lives in an urban area, and " 0 - otherwise. We use the aggregation level of the Multinational Time Use Study version of the STUS, which considers that the individual lives in an urban area if the city has 50,000 inhabitants or more, and in a rural area if there are less than 50,000 inhabitants. *Significant at the $90 \%$ level $* *$ Significant at the $95 \%$ level ***Significant at the $99 \%$ level. 
Table C5. Results including dummy as indicator of living in couple, men

\begin{tabular}{|c|c|c|c|c|c|}
\hline Men & $\begin{array}{c}\text { (1) } \\
\text { Study } \\
\end{array}$ & $\begin{array}{c}(2) \\
\text { Job } \\
\text { Search } \\
\end{array}$ & $\begin{array}{c}(3) \\
\text { Household } \\
\text { production }\end{array}$ & $\begin{array}{c}(4) \\
\text { Personal } \\
\text { Care } \\
\end{array}$ & Leisure \\
\hline Age & $\begin{array}{l}-0.026 \\
(0.024)\end{array}$ & $\begin{array}{l}-0.020 \\
(0.016)\end{array}$ & $\begin{array}{c}0.151 * * * \\
(0.030)\end{array}$ & $\begin{array}{l}-0.035 \\
(0.022)\end{array}$ & $\begin{array}{l}-0.081 \\
(0.074)\end{array}$ \\
\hline Age squared & $\begin{array}{c}0.021 \\
(0.028)\end{array}$ & $\begin{array}{c}0.002 \\
(0.012)\end{array}$ & $\begin{array}{c}-0.160 * * * \\
(0.042)\end{array}$ & $\begin{array}{c}0.031 \\
(0.025)\end{array}$ & $\begin{array}{c}0.123 \\
(0.082)\end{array}$ \\
\hline Secondary education & $\begin{array}{c}0.232 * * * \\
(0.060)\end{array}$ & $\begin{array}{c}-0.065 \\
(0.041)\end{array}$ & $\begin{array}{c}0.481 * * * \\
(0.161)\end{array}$ & $\begin{array}{c}-0.475^{* * *} \\
(0.061)\end{array}$ & $\begin{array}{c}-0.209 \\
(0.245)\end{array}$ \\
\hline University education & $\begin{array}{c}1.125 * * * \\
(0.165)\end{array}$ & $\begin{array}{l}-0.108 \\
(0.072)\end{array}$ & $\begin{array}{c}0.554 * * * \\
(0.139)\end{array}$ & $\begin{array}{c}-0.702^{* * *} \\
(0.184)\end{array}$ & $\begin{array}{c}-0.682 * * * \\
(0.129)\end{array}$ \\
\hline Number of children & $\begin{array}{l}-0.031 \\
(0.022)\end{array}$ & $\begin{array}{l}-0.013 \\
(0.026)\end{array}$ & $\begin{array}{c}0.337 * * * \\
(0.054)\end{array}$ & $\begin{array}{c}-0.172^{* * *} \\
(0.039)\end{array}$ & $\begin{array}{c}-0.133^{*} \\
(0.065)\end{array}$ \\
\hline Paid housekeeping & $\begin{array}{l}-0.015 \\
(0.151)\end{array}$ & $\begin{array}{l}-0.048 \\
(0.154)\end{array}$ & $\begin{array}{c}0.804^{* *} \\
(0.367)\end{array}$ & $\begin{array}{l}-0.351 \\
(0.478)\end{array}$ & $\begin{array}{l}-0.303 \\
(0.485)\end{array}$ \\
\hline Bad health & $\begin{array}{c}0.119 \\
(0.120)\end{array}$ & $\begin{array}{l}-0.087 \\
(0.111)\end{array}$ & $\begin{array}{c}0.170 \\
(0.107)\end{array}$ & $\begin{array}{l}-0.048 \\
(0.274)\end{array}$ & $\begin{array}{c}0.046 \\
(0.243)\end{array}$ \\
\hline Poor health & $\begin{array}{l}-0.027 \\
(0.124)\end{array}$ & $\begin{array}{c}-0.016 \\
(0.106)\end{array}$ & $\begin{array}{c}0.152 \\
(0.189)\end{array}$ & $\begin{array}{c}0.079 \\
(0.261)\end{array}$ & $\begin{array}{c}0.083 \\
(0.187)\end{array}$ \\
\hline Good health & $\begin{array}{c}-0.219 * * * \\
(0.069)\end{array}$ & $\begin{array}{c}-0.029 \\
(0.050)\end{array}$ & $\begin{array}{c}0.155 \\
(0.197)\end{array}$ & $\begin{array}{c}0.796 * * * \\
(0.189)\end{array}$ & $\begin{array}{l}-0.381^{*} \\
(0.217)\end{array}$ \\
\hline Very good health & $\begin{array}{c}0.271 \\
(0.453)\end{array}$ & $\begin{array}{c}-0.455^{* * *} \\
(0.084)\end{array}$ & $\begin{array}{l}-1.107 \\
(0.694)\end{array}$ & $\begin{array}{c}0.977 \\
(0.796)\end{array}$ & $\begin{array}{c}0.714 \\
(1.077)\end{array}$ \\
\hline Hhld income 1201-2000 € & $\begin{array}{c}0.426 * * * \\
(0.102)\end{array}$ & $\begin{array}{c}-0.385^{* * * *} \\
(0.058)\end{array}$ & $\begin{array}{l}-0.019 \\
(0.154)\end{array}$ & $\begin{array}{c}-0.060 \\
(0.133)\end{array}$ & $\begin{array}{c}0.056 \\
(0.213)\end{array}$ \\
\hline Hhld income 2001-3000€ & $\begin{array}{c}0.009 \\
(0.146)\end{array}$ & $\begin{array}{l}-0.056 \\
(0.077)\end{array}$ & $\begin{array}{l}-0.324 \\
(0.402)\end{array}$ & $\begin{array}{c}0.022 \\
(0.372)\end{array}$ & $\begin{array}{c}0.342 \\
(0.503)\end{array}$ \\
\hline Hhld income $>3000 €$ & $\begin{array}{c}0.138 \\
(0.515)\end{array}$ & $\begin{array}{l}-0.146 \\
(0.100)\end{array}$ & $\begin{array}{c}-1.653 * * * \\
(0.373)\end{array}$ & $\begin{array}{c}1.197 * * * \\
(0.259)\end{array}$ & $\begin{array}{l}0.481 * \\
(0.271)\end{array}$ \\
\hline Consumer price index & $\begin{array}{c}-0.012 \\
(0.017)\end{array}$ & $\begin{array}{c}0.026 * * \\
(0.011)\end{array}$ & $\begin{array}{c}0.029 \\
(0.030)\end{array}$ & $\begin{array}{l}-0.005 \\
(0.024)\end{array}$ & $\begin{array}{l}-0.066 \\
(0.041)\end{array}$ \\
\hline Gross domestic product & $\begin{array}{c}-0.024 * \\
(0.011)\end{array}$ & $\begin{array}{c}-0.010 \\
(0.010)\end{array}$ & $\begin{array}{l}-0.007 \\
(0.023)\end{array}$ & $\begin{array}{l}0.020^{*} \\
(0.011)\end{array}$ & $\begin{array}{c}0.025 \\
(0.020)\end{array}$ \\
\hline Activity rate of the region & $\begin{array}{c}-0.009 \\
(0.014)\end{array}$ & $\begin{array}{c}0.013 \\
(0.016)\end{array}$ & $\begin{array}{l}-0.008 \\
(0.018)\end{array}$ & $\begin{array}{c}0.027 \\
(0.017)\end{array}$ & $\begin{array}{l}-0.012 \\
(0.038)\end{array}$ \\
\hline Income per capita & $\begin{array}{c}0.014^{* *} \\
(0.005)\end{array}$ & $\begin{array}{c}0.015^{* *} \\
(0.006)\end{array}$ & $\begin{array}{c}0.001 \\
(0.010)\end{array}$ & $\begin{array}{c}-0.014 * * \\
(0.005)\end{array}$ & $\begin{array}{c}-0.020^{* * *} \\
(0.006)\end{array}$ \\
\hline Divorce rates & $\begin{array}{l}-0.067 \\
(0.107)\end{array}$ & $\begin{array}{c}-0.239 * * \\
(0.105)\end{array}$ & $\begin{array}{l}0.230 * \\
(0.124)\end{array}$ & $\begin{array}{c}-0.053 \\
(0.102)\end{array}$ & $\begin{array}{c}0.226 \\
(0.200)\end{array}$ \\
\hline$\%$ people in region with very poor health & $\begin{array}{c}0.059 \\
(0.056)\end{array}$ & $\begin{array}{c}0.036 \\
(0.027)\end{array}$ & $\begin{array}{c}0.054 \\
(0.076)\end{array}$ & $\begin{array}{c}-0.095^{*} \\
(0.046)\end{array}$ & $\begin{array}{l}-0.104 \\
(0.096)\end{array}$ \\
\hline$\%$ people in region with poor health & $\begin{array}{c}0.042 \\
(0.048)\end{array}$ & $\begin{array}{c}0.038 \\
(0.024)\end{array}$ & $\begin{array}{c}0.014 \\
(0.064)\end{array}$ & $\begin{array}{c}-0.097 * * \\
(0.042)\end{array}$ & $\begin{array}{l}-0.056 \\
(0.078)\end{array}$ \\
\hline$\%$ people in region with good health & $\begin{array}{c}0.070 \\
(0.045)\end{array}$ & $\begin{array}{l}0.045^{*} \\
(0.023)\end{array}$ & $\begin{array}{c}-0.006 \\
(0.072)\end{array}$ & $\begin{array}{c}-0.110^{* *} \\
(0.040)\end{array}$ & $\begin{array}{c}-0.064 \\
(0.080)\end{array}$ \\
\hline Share of public jobs relative to private & $\begin{array}{c}0.019 * * \\
(0.007)\end{array}$ & $\begin{array}{c}0.013 \\
(0.009)\end{array}$ & $\begin{array}{l}0.024^{*} \\
(0.012)\end{array}$ & $\begin{array}{l}-0.028 * * \\
(0.010)\end{array}$ & $\begin{array}{l}-0.019 \\
(0.017)\end{array}$ \\
\hline Industrial production index & $\begin{array}{l}-0.004 \\
(0.008)\end{array}$ & $\begin{array}{l}-0.011^{*} \\
(0.006)\end{array}$ & $\begin{array}{c}0.034 * * * \\
(0.009)\end{array}$ & $\begin{array}{l}-0.010 \\
(0.012)\end{array}$ & $\begin{array}{c}0.004 \\
(0.014)\end{array}$ \\
\hline Industrial price index & $\begin{array}{c}-0.025^{* * *} \\
(0.006)\end{array}$ & $\begin{array}{c}-0.038 * * \\
(0.014)\end{array}$ & $\begin{array}{c}0.013 \\
(0.016)\end{array}$ & $\begin{array}{c}0.020 \\
(0.011)\end{array}$ & $\begin{array}{l}0.055^{* *} \\
(0.023)\end{array}$ \\
\hline Constant & $\begin{array}{l}-1.192 \\
(5.233)\end{array}$ & $\begin{array}{l}-1.861 \\
(2.536)\end{array}$ & $\begin{array}{l}-9.686 \\
(7.573)\end{array}$ & $\begin{array}{l}21.950 * * * \\
(5.135)\end{array}$ & $\begin{array}{c}18.019 * * \\
(7.106)\end{array}$ \\
\hline $\begin{array}{c}\text { N Observations } \\
\text { Pseudo R-squared }\end{array}$ & $\begin{array}{l}1,884 \\
0.112\end{array}$ & $\begin{array}{l}1,884 \\
0.076\end{array}$ & $\begin{array}{l}1,884 \\
0.160\end{array}$ & $\begin{array}{l}1,884 \\
0.071\end{array}$ & $\begin{array}{l}1,884 \\
0.122\end{array}$ \\
\hline
\end{tabular}

Notes: Robust standard errors in parentheses. Sample consists of respondents aged 21-65 who are unemployed, from the Spanish Time Use Survey (STUS) 2002-2003 and 2009-2010. Regional Unemployment Rates comes from the Spanish Statistical Office (Instituto Nacional de Estadística), defined at the level of the 17 autonomous regions in Spain (Ceuta and Melilla are excluded from the analysis). Definitions of time use variables can be found in Appendix Table B1. Time use variables are measured in hours per day. In couple is a dummy variable that takes value " 1 " if the respondent is married or cohabiting, and " 0 " otherwise. *Significant at the $90 \%$ level **Significant at the $95 \%$ level ***Significant at the $99 \%$ level. 
Table C6. Results including dummy as indicator of living in couple, women

\begin{tabular}{|c|c|c|c|c|c|}
\hline Women & Study & $\begin{array}{c}(2) \\
\text { Job } \\
\text { Search } \\
\end{array}$ & $\begin{array}{c}\text { (3) } \\
\text { Household } \\
\text { production }\end{array}$ & $\begin{array}{c}(4) \\
\text { Personal } \\
\text { Care } \\
\end{array}$ & Leisure \\
\hline Age & $\begin{array}{l}-0.010 \\
(0.016)\end{array}$ & $\begin{array}{c}0.015 \\
(0.010)\end{array}$ & $\begin{array}{c}0.210^{* * *} \\
(0.034)\end{array}$ & $\begin{array}{c}-0.068 * * \\
(0.031)\end{array}$ & $\begin{array}{c}-0.149 * * * \\
(0.022)\end{array}$ \\
\hline Age squared & $\begin{array}{c}0.004 \\
(0.021)\end{array}$ & $\begin{array}{l}-0.024^{*} \\
(0.013)\end{array}$ & $\begin{array}{c}-0.221 * * * \\
(0.041)\end{array}$ & $\begin{array}{c}0.050 \\
(0.043)\end{array}$ & $\begin{array}{c}0.189 * * * \\
(0.029)\end{array}$ \\
\hline Secondary education & $\begin{array}{c}0.095 \\
(0.060)\end{array}$ & $\begin{array}{c}0.014 \\
(0.019)\end{array}$ & $\begin{array}{c}0.007 \\
(0.062)\end{array}$ & $\begin{array}{c}0.052 \\
(0.061)\end{array}$ & $\begin{array}{l}-0.041 \\
(0.075)\end{array}$ \\
\hline University education & $\begin{array}{c}0.797 * * * \\
(0.052)\end{array}$ & $\begin{array}{l}-0.041^{*} \\
(0.023)\end{array}$ & $\begin{array}{c}-0.535^{* * *} \\
(0.071)\end{array}$ & $\begin{array}{l}-0.188 \\
(0.126)\end{array}$ & $\begin{array}{c}0.120 \\
(0.179)\end{array}$ \\
\hline Number of children & $\begin{array}{c}-0.101^{* * *} \\
(0.010)\end{array}$ & $\begin{array}{c}-0.051^{* * *} \\
(0.014)\end{array}$ & $\begin{array}{c}0.916 * * * \\
(0.130)\end{array}$ & $\begin{array}{c}-0.098 * * \\
(0.042)\end{array}$ & $\begin{array}{c}-0.611^{* * * *} \\
(0.092)\end{array}$ \\
\hline Paid housekeeping & $\begin{array}{c}-0.406^{* *} \\
(0.144)\end{array}$ & $\begin{array}{c}-0.112 * * \\
(0.043)\end{array}$ & $\begin{array}{l}-0.505 \\
(0.477)\end{array}$ & $\begin{array}{c}-0.597 * * * \\
(0.174)\end{array}$ & $\begin{array}{c}1.469 * * * \\
(0.498)\end{array}$ \\
\hline Bad health & $\begin{array}{c}0.394 * * * \\
(0.131)\end{array}$ & $\begin{array}{c}-0.103^{*} \\
(0.049)\end{array}$ & $\begin{array}{l}-0.291 * \\
(0.155)\end{array}$ & $\begin{array}{c}-0.394^{* * *} \\
(0.125)\end{array}$ & $\begin{array}{c}0.270 * * \\
(0.122)\end{array}$ \\
\hline Poor health & $\begin{array}{c}0.169 * * \\
(0.077)\end{array}$ & $\begin{array}{l}-0.052 \\
(0.054)\end{array}$ & $\begin{array}{l}-0.028 \\
(0.158)\end{array}$ & $\begin{array}{c}-0.373 * * * \\
(0.109)\end{array}$ & $\begin{array}{c}0.163 \\
(0.105)\end{array}$ \\
\hline Good health & $\begin{array}{c}-0.135^{* *} \\
(0.051)\end{array}$ & $\begin{array}{c}-0.015 \\
(0.044)\end{array}$ & $\begin{array}{c}-0.691 * * * \\
(0.231)\end{array}$ & $\begin{array}{c}0.034 \\
(0.088)\end{array}$ & $\begin{array}{c}0.669 * * * \\
(0.175)\end{array}$ \\
\hline Very good health & $\begin{array}{c}0.244 \\
(0.722)\end{array}$ & $\begin{array}{c}-0.214^{* * *} \\
(0.047)\end{array}$ & $\begin{array}{c}-0.655 \\
(0.759)\end{array}$ & $\begin{array}{c}2.965^{* * *} * \\
(0.308)\end{array}$ & $\begin{array}{c}-2.219 * * * \\
(0.541)\end{array}$ \\
\hline Hhld income 1201-2000 € & $\begin{array}{c}0.022 \\
(0.071)\end{array}$ & $\begin{array}{c}0.049 * * * \\
(0.011)\end{array}$ & $\begin{array}{c}-0.169 * * \\
(0.062)\end{array}$ & $\begin{array}{c}-0.036 \\
(0.087)\end{array}$ & $\begin{array}{c}0.086 \\
(0.054)\end{array}$ \\
\hline Hhld income 2001-3000€ & $\begin{array}{l}-0.236 \\
(0.209)\end{array}$ & $\begin{array}{c}-0.090 * * \\
(0.039)\end{array}$ & $\begin{array}{c}0.002 \\
(0.259)\end{array}$ & $\begin{array}{c}0.271 \\
(0.206)\end{array}$ & $\begin{array}{c}0.040 \\
(0.271)\end{array}$ \\
\hline Hhld income $>3000 €$ & $\begin{array}{l}-0.612 \\
(0.405)\end{array}$ & $\begin{array}{c}0.005 \\
(0.076)\end{array}$ & $\begin{array}{l}-0.010 \\
(0.886)\end{array}$ & $\begin{array}{c}1.533^{* *} \\
(0.711)\end{array}$ & $\begin{array}{l}-0.924 \\
(0.660)\end{array}$ \\
\hline Consumer price index & $\begin{array}{l}-0.038 \\
(0.030)\end{array}$ & $\begin{array}{c}0.007 \\
(0.007)\end{array}$ & $\begin{array}{c}0.045 \\
(0.028)\end{array}$ & $\begin{array}{l}0.062^{*} \\
(0.032)\end{array}$ & $\begin{array}{c}-0.054 * * * \\
(0.017)\end{array}$ \\
\hline Gross domestic product & $\begin{array}{l}0.015^{*} \\
(0.007)\end{array}$ & $\begin{array}{c}0.002 \\
(0.005)\end{array}$ & $\begin{array}{l}-0.026 \\
(0.016)\end{array}$ & $\begin{array}{c}-0.033^{* * * *} \\
(0.008)\end{array}$ & $\begin{array}{c}0.047 * * \\
(0.017)\end{array}$ \\
\hline Activity rate of the region & $\begin{array}{c}0.007 \\
(0.043)\end{array}$ & $\begin{array}{l}0.030 * \\
(0.016)\end{array}$ & $\begin{array}{c}0.048 \\
(0.038)\end{array}$ & $\begin{array}{l}-0.064 \\
(0.053)\end{array}$ & $\begin{array}{l}-0.058^{*} \\
(0.029)\end{array}$ \\
\hline Income per capita & $\begin{array}{l}-0.004 \\
(0.007)\end{array}$ & $\begin{array}{c}0.000 \\
(0.003)\end{array}$ & $\begin{array}{l}0.021^{*} \\
(0.010)\end{array}$ & $\begin{array}{c}0.009 \\
(0.012)\end{array}$ & $\begin{array}{c}-0.034 * * \\
(0.012)\end{array}$ \\
\hline Divorce rates & $\begin{array}{l}-0.085 \\
(0.099)\end{array}$ & $\begin{array}{c}-0.135 * * \\
(0.062)\end{array}$ & $\begin{array}{l}-0.032 \\
(0.121)\end{array}$ & $\begin{array}{l}-0.070 \\
(0.159)\end{array}$ & $\begin{array}{l}0.353^{*} \\
(0.181)\end{array}$ \\
\hline$\%$ people in region with very poor health & $\begin{array}{l}-0.012 \\
(0.025)\end{array}$ & $\begin{array}{c}0.007 \\
(0.013)\end{array}$ & $\begin{array}{l}-0.080 \\
(0.048)\end{array}$ & $\begin{array}{c}0.024 \\
(0.053)\end{array}$ & $\begin{array}{c}0.103 \\
(0.065)\end{array}$ \\
\hline$\%$ people in region with poor health & $\begin{array}{l}-0.027 \\
(0.025)\end{array}$ & $\begin{array}{c}0.011 \\
(0.014)\end{array}$ & $\begin{array}{l}-0.031 \\
(0.052)\end{array}$ & $\begin{array}{l}-0.004 \\
(0.058)\end{array}$ & $\begin{array}{c}0.083 \\
(0.065)\end{array}$ \\
\hline$\%$ people in region with good health & $\begin{array}{l}-0.048 \\
(0.041)\end{array}$ & $\begin{array}{c}0.023 \\
(0.019)\end{array}$ & $\begin{array}{c}0.031 \\
(0.087)\end{array}$ & $\begin{array}{c}-0.006 \\
(0.090)\end{array}$ & $\begin{array}{c}0.032 \\
(0.098)\end{array}$ \\
\hline Share of public jobs relative to private & $\begin{array}{c}0.021 \\
(0.023)\end{array}$ & $\begin{array}{c}0.003 \\
(0.005)\end{array}$ & $\begin{array}{c}0.009 \\
(0.017)\end{array}$ & $\begin{array}{c}-0.064 * * * \\
(0.018)\end{array}$ & $\begin{array}{c}0.003 \\
(0.023)\end{array}$ \\
\hline Industrial production index & $\begin{array}{l}-0.014 \\
(0.019)\end{array}$ & $\begin{array}{l}-0.001 \\
(0.003)\end{array}$ & $\begin{array}{c}0.008 \\
(0.012)\end{array}$ & $\begin{array}{c}0.017 \\
(0.020)\end{array}$ & $\begin{array}{l}-0.004 \\
(0.017)\end{array}$ \\
\hline Industrial price index & $\begin{array}{c}0.025^{* * * *} \\
(0.005)\end{array}$ & $\begin{array}{c}-0.014 * * * \\
(0.004)\end{array}$ & $\begin{array}{c}-0.070 * * * \\
(0.012)\end{array}$ & $\begin{array}{l}-0.009 \\
(0.012)\end{array}$ & $\begin{array}{c}0.072 * * * \\
(0.014)\end{array}$ \\
\hline Constant & $\begin{array}{c}5.287 \\
(4.051)\end{array}$ & $\begin{array}{l}-1.245 \\
(1.398)\end{array}$ & $\begin{array}{l}-0.104 \\
(4.844)\end{array}$ & $\begin{array}{l}9.885^{*} \\
(5.165)\end{array}$ & $\begin{array}{c}7.128 \\
(6.710)\end{array}$ \\
\hline $\begin{array}{c}\text { N Observations } \\
\text { Pseudo R-squared }\end{array}$ & $\begin{array}{l}2,238 \\
0.121 \\
\end{array}$ & $\begin{array}{l}2,238 \\
0.051 \\
\end{array}$ & $\begin{array}{l}2,238 \\
0.403 \\
\end{array}$ & $\begin{array}{l}2,238 \\
0.148 \\
\end{array}$ & $\begin{array}{l}2,238 \\
0.178 \\
\end{array}$ \\
\hline
\end{tabular}

Notes: Robust standard errors in parentheses. Sample consists of respondents aged 21-65 who are unemployed, from the Spanish Time Use Survey (STUS) 2002-2003 and 2009-2010. Regional Unemployment Rates comes from the Spanish Statistical Office (Instituto Nacional de Estadística), defined at the level of the 17 autonomous regions in Spain (Ceuta and Melilla are excluded from the analysis). Definitions of time use variables can be found in Appendix Table B1. Time use variables are measured in hours per day. In couple is a dummy variable that takes value " 1 " if the respondent is married or cohabiting, and " 0 " otherwise. *Significant at the $90 \%$ level **Significant at the $95 \%$ level ***Significant at the $99 \%$ level. 
Table C7. Results including dummy as indicator of having a working partner, men

\begin{tabular}{|c|c|c|c|c|c|}
\hline Men & $\begin{array}{c}\text { (1) } \\
\text { Study }\end{array}$ & $\begin{array}{c}(2) \\
\text { Job } \\
\text { Search }\end{array}$ & $\begin{array}{c}(3) \\
\text { Household } \\
\text { production }\end{array}$ & $\begin{array}{c}(4) \\
\text { Personal } \\
\text { Care }\end{array}$ & $\begin{array}{c}\text { (5) } \\
\text { Leisure }\end{array}$ \\
\hline Age & $\begin{array}{l}-0.034 \\
(0.025)\end{array}$ & $\begin{array}{l}-0.015 \\
(0.014)\end{array}$ & $\begin{array}{c}0.139 * * * \\
(0.029)\end{array}$ & $\begin{array}{c}-0.027 \\
(0.022)\end{array}$ & $\begin{array}{c}-0.073 \\
(0.077)\end{array}$ \\
\hline Age squared & $\begin{array}{c}0.025 \\
(0.028)\end{array}$ & $\begin{array}{c}0.001 \\
(0.011)\end{array}$ & $\begin{array}{c}-0.126^{* * *} \\
(0.043)\end{array}$ & $\begin{array}{c}0.026 \\
(0.026)\end{array}$ & $\begin{array}{c}0.086 \\
(0.087)\end{array}$ \\
\hline Secondary education & $\begin{array}{c}0.226 * * * \\
(0.058)\end{array}$ & $\begin{array}{l}-0.060 \\
(0.041)\end{array}$ & $\begin{array}{c}0.409 * * \\
(0.175)\end{array}$ & $\begin{array}{c}-0.468 * * * \\
(0.061)\end{array}$ & $\begin{array}{l}-0.130 \\
(0.265)\end{array}$ \\
\hline University education & $\begin{array}{c}1.121^{* * *} \\
(0.164)\end{array}$ & $\begin{array}{l}-0.096 \\
(0.063)\end{array}$ & $\begin{array}{c}0.504 * * * \\
(0.129)\end{array}$ & $\begin{array}{c}-0.706^{* * *} \\
(0.200)\end{array}$ & $\begin{array}{c}-0.630 * * * \\
(0.125)\end{array}$ \\
\hline Number of children & $\begin{array}{c}-0.077^{* * *} \\
(0.011)\end{array}$ & $\begin{array}{c}0.039 \\
(0.027)\end{array}$ & $\begin{array}{c}0.578 * * * \\
(0.061)\end{array}$ & $\begin{array}{c}-0.115^{* *} \\
(0.040)\end{array}$ & $\begin{array}{c}-0.439 * * * \\
(0.070)\end{array}$ \\
\hline Paid housekeeping & $\begin{array}{c}0.017 \\
(0.142)\end{array}$ & $\begin{array}{l}-0.075 \\
(0.157)\end{array}$ & $\begin{array}{l}0.690^{*} \\
(0.364)\end{array}$ & $\begin{array}{c}-0.396 \\
(0.479)\end{array}$ & $\begin{array}{c}-0.153 \\
(0.486)\end{array}$ \\
\hline Bad health & $\begin{array}{c}0.110 \\
(0.119)\end{array}$ & $\begin{array}{l}-0.078 \\
(0.104)\end{array}$ & $\begin{array}{c}0.191 \\
(0.129)\end{array}$ & $\begin{array}{l}-0.039 \\
(0.272)\end{array}$ & $\begin{array}{c}0.015 \\
(0.276)\end{array}$ \\
\hline Poor health & $\begin{array}{l}-0.034 \\
(0.121)\end{array}$ & $\begin{array}{l}-0.007 \\
(0.098)\end{array}$ & $\begin{array}{c}0.160 \\
(0.200)\end{array}$ & $\begin{array}{c}0.078 \\
(0.250)\end{array}$ & $\begin{array}{c}0.067 \\
(0.211)\end{array}$ \\
\hline Good health & $\begin{array}{c}-0.218 * * * \\
(0.054)\end{array}$ & $\begin{array}{l}-0.023 \\
(0.043)\end{array}$ & $\begin{array}{c}0.154 \\
(0.199)\end{array}$ & $\begin{array}{c}0.797 * * * \\
(0.193)\end{array}$ & $\begin{array}{l}-0.377 \\
(0.232)\end{array}$ \\
\hline Very good health & $\begin{array}{c}0.266 \\
(0.424)\end{array}$ & $\begin{array}{c}-0.476 * * * \\
(0.085)\end{array}$ & $\begin{array}{l}-1.194 \\
(0.773)\end{array}$ & $\begin{array}{c}0.983 \\
(0.830)\end{array}$ & $\begin{array}{c}0.806 \\
(1.051)\end{array}$ \\
\hline Hhld income 1201-2000 $€$ & $\begin{array}{c}0.416^{* * *} \\
(0.106)\end{array}$ & $\begin{array}{c}-0.381^{* * *} \\
(0.055)\end{array}$ & $\begin{array}{l}-0.140 \\
(0.169)\end{array}$ & $\begin{array}{l}-0.045 \\
(0.152)\end{array}$ & $\begin{array}{c}0.188 \\
(0.253)\end{array}$ \\
\hline Hhld income 2001-3000 $€$ & $\begin{array}{c}0.003 \\
(0.162)\end{array}$ & $\begin{array}{l}-0.062 \\
(0.088)\end{array}$ & $\begin{array}{l}-0.541 \\
(0.414)\end{array}$ & $\begin{array}{c}0.033 \\
(0.373)\end{array}$ & $\begin{array}{c}0.588 \\
(0.509)\end{array}$ \\
\hline Hhld income $>3000 €$ & $\begin{array}{c}0.110 \\
(0.497)\end{array}$ & $\begin{array}{c}-0.135 \\
(0.091)\end{array}$ & $\begin{array}{c}-1.761 * * * \\
(0.492)\end{array}$ & $\begin{array}{c}1.254 * * * \\
(0.271)\end{array}$ & $\begin{array}{c}0.592 * * * \\
(0.161)\end{array}$ \\
\hline Consumer price index & $\begin{array}{l}-0.016 \\
(0.019)\end{array}$ & $\begin{array}{c}0.027 * * \\
(0.011)\end{array}$ & $\begin{array}{c}0.028 \\
(0.028)\end{array}$ & $\begin{array}{c}0.003 \\
(0.024)\end{array}$ & $\begin{array}{l}-0.067 \\
(0.040)\end{array}$ \\
\hline Gross domestic product & $\begin{array}{c}-0.025^{*} \\
(0.012)\end{array}$ & $\begin{array}{l}-0.010 \\
(0.010)\end{array}$ & $\begin{array}{l}-0.010 \\
(0.021)\end{array}$ & $\begin{array}{l}0.022^{*} \\
(0.011)\end{array}$ & $\begin{array}{c}0.027 \\
(0.019)\end{array}$ \\
\hline Activity rate of the region & $\begin{array}{l}-0.011 \\
(0.013)\end{array}$ & $\begin{array}{c}0.011 \\
(0.016)\end{array}$ & $\begin{array}{l}-0.024 \\
(0.015)\end{array}$ & $\begin{array}{l}0.031^{*} \\
(0.017)\end{array}$ & $\begin{array}{c}0.005 \\
(0.032)\end{array}$ \\
\hline Income per capita & $\begin{array}{c}0.014^{* *} \\
(0.005)\end{array}$ & $\begin{array}{c}0.015^{* *} \\
(0.006)\end{array}$ & $\begin{array}{c}0.005 \\
(0.009)\end{array}$ & $\begin{array}{c}-0.013^{* *} \\
(0.005)\end{array}$ & $\begin{array}{c}-0.025 * * * \\
(0.007)\end{array}$ \\
\hline Divorce rates & $\begin{array}{l}-0.047 \\
(0.096)\end{array}$ & $\begin{array}{c}-0.256^{* *} \\
(0.112)\end{array}$ & $\begin{array}{c}0.181 \\
(0.128)\end{array}$ & $\begin{array}{l}-0.080 \\
(0.102)\end{array}$ & $\begin{array}{c}0.295 \\
(0.194)\end{array}$ \\
\hline \% people in region with very poor health & $\begin{array}{c}0.062 \\
(0.054)\end{array}$ & $\begin{array}{c}0.033 \\
(0.027)\end{array}$ & $\begin{array}{c}0.019 \\
(0.059)\end{array}$ & $\begin{array}{c}-0.100 * * \\
(0.046)\end{array}$ & $\begin{array}{l}-0.062 \\
(0.086)\end{array}$ \\
\hline$\%$ people in region with poor health & $\begin{array}{c}0.045 \\
(0.047)\end{array}$ & $\begin{array}{c}0.035 \\
(0.023)\end{array}$ & $\begin{array}{l}-0.023 \\
(0.051)\end{array}$ & $\begin{array}{c}-0.100 * * \\
(0.042)\end{array}$ & $\begin{array}{l}-0.012 \\
(0.072)\end{array}$ \\
\hline$\%$ people in region with good health & $\begin{array}{c}0.073 \\
(0.044)\end{array}$ & $\begin{array}{l}0.041^{*} \\
(0.022)\end{array}$ & $\begin{array}{c}-0.051 \\
(0.057)\end{array}$ & $\begin{array}{c}-0.115^{* *} \\
(0.040)\end{array}$ & $\begin{array}{l}-0.010 \\
(0.070)\end{array}$ \\
\hline Share of public jobs relative to private & $\begin{array}{c}0.021 * * * \\
(0.006)\end{array}$ & $\begin{array}{c}0.010 \\
(0.010)\end{array}$ & $\begin{array}{c}0.017 \\
(0.011)\end{array}$ & $\begin{array}{c}-0.031 * * \\
(0.011)\end{array}$ & $\begin{array}{l}-0.009 \\
(0.018)\end{array}$ \\
\hline Industrial production index & $\begin{array}{l}-0.003 \\
(0.008)\end{array}$ & $\begin{array}{l}-0.011^{*} \\
(0.006)\end{array}$ & $\begin{array}{c}0.029 * * * \\
(0.008)\end{array}$ & $\begin{array}{l}-0.011 \\
(0.012)\end{array}$ & $\begin{array}{c}0.010 \\
(0.015)\end{array}$ \\
\hline Industrial price index & $\begin{array}{c}-0.022 * * * \\
(0.006)\end{array}$ & $\begin{array}{c}-0.040 * * \\
(0.015)\end{array}$ & $\begin{array}{c}0.005 \\
(0.015)\end{array}$ & $\begin{array}{c}0.015 \\
(0.011)\end{array}$ & $\begin{array}{l}0.065^{* *} \\
(0.024)\end{array}$ \\
\hline Constant & $\begin{array}{l}-1.288 \\
(5.175)\end{array}$ & $\begin{array}{l}-1.432 \\
(2.590)\end{array}$ & $\begin{array}{l}-4.239 \\
(5.848)\end{array}$ & $\begin{array}{l}21.941 * * * \\
(5.057)\end{array}$ & $\begin{array}{l}11.713 \\
(6.982)\end{array}$ \\
\hline $\begin{array}{l}\text { N Observations } \\
\text { Pseudo R-squared }\end{array}$ & $\begin{array}{l}1,884 \\
0.110\end{array}$ & $\begin{array}{l}1,884 \\
0.074\end{array}$ & $\begin{array}{l}1,884 \\
0.154\end{array}$ & $\begin{array}{l}1,884 \\
0.070\end{array}$ & $\begin{array}{l}1,884 \\
0.113\end{array}$ \\
\hline
\end{tabular}

Notes: Robust standard errors in parentheses. Sample consists of respondents aged 21-65 who are unemployed, from the Spanish Time Use Survey (STUS) 2002-2003 and 2009-2010. Regional Unemployment Rates comes from the Spanish Statistical Office (Instituto Nacional de Estadística), defined at the level of the 17 autonomous regions in Spain (Ceuta and Melilla are excluded from the analysis). Definitions of time use variables can be found in Appendix Table B1. Time use variables are measured in hours per day. Partner working is a dummy variable that takes value " 1 " if respondent's partner works (part- or full-time), and value " 0 " otherwise. *Significant at the $90 \%$ level **Significant at the $95 \%$ level ***Significant at the $99 \%$ level. 
Table C8. Results including dummy as indicator of having a working partner, women

\begin{tabular}{|c|c|c|c|c|c|}
\hline Women & $\begin{array}{c}\text { (1) } \\
\text { Study } \\
\end{array}$ & $\begin{array}{c}(2) \\
\text { Job } \\
\text { Search } \\
\end{array}$ & $\begin{array}{c}\text { (3) } \\
\text { Household } \\
\text { production }\end{array}$ & $\begin{array}{c}(4) \\
\text { Personal } \\
\text { Care } \\
\end{array}$ & Leisure \\
\hline Age & $\begin{array}{c}-0.034 * * \\
(0.015)\end{array}$ & $\begin{array}{c}0.012 \\
(0.011)\end{array}$ & $\begin{array}{c}0.283 * * * \\
(0.031)\end{array}$ & $\begin{array}{c}-0.086 * * \\
(0.030)\end{array}$ & $\begin{array}{c}-0.173 * * * \\
(0.022)\end{array}$ \\
\hline Age squared & $\begin{array}{c}0.025 \\
(0.019)\end{array}$ & $\begin{array}{l}-0.022 \\
(0.015)\end{array}$ & $\begin{array}{c}-0.283 * * * \\
(0.041)\end{array}$ & $\begin{array}{c}0.067 \\
(0.044)\end{array}$ & $\begin{array}{c}0.208 * * * \\
(0.030)\end{array}$ \\
\hline Secondary education & $\begin{array}{c}0.151^{* *} \\
(0.057)\end{array}$ & $\begin{array}{c}0.023 \\
(0.019)\end{array}$ & $\begin{array}{c}-0.185^{* *} \\
(0.075)\end{array}$ & $\begin{array}{c}0.104 \\
(0.066)\end{array}$ & $\begin{array}{c}0.032 \\
(0.075)\end{array}$ \\
\hline University education & $\begin{array}{c}0.870^{* * * *} \\
(0.060)\end{array}$ & $\begin{array}{l}-0.026 \\
(0.026)\end{array}$ & $\begin{array}{c}-0.791 * * * \\
(0.107)\end{array}$ & $\begin{array}{l}-0.129 \\
(0.109)\end{array}$ & $\begin{array}{c}0.221 \\
(0.182)\end{array}$ \\
\hline Number of children & $\begin{array}{c}-0.147 * * * \\
(0.011)\end{array}$ & $\begin{array}{c}-0.059 * * * \\
(0.014)\end{array}$ & $\begin{array}{c}1.073 * * * \\
(0.120)\end{array}$ & $\begin{array}{c}-0.132 * * * \\
(0.034)\end{array}$ & $\begin{array}{c}-0.673 * * * \\
(0.087)\end{array}$ \\
\hline Paid housekeeping & $\begin{array}{c}-0.348^{* *} \\
(0.149)\end{array}$ & $\begin{array}{c}-0.100^{* *} \\
(0.042)\end{array}$ & $\begin{array}{l}-0.719 \\
(0.517)\end{array}$ & $\begin{array}{c}-0.546 * * * \\
(0.162)\end{array}$ & $\begin{array}{c}1.557 * * * \\
(0.519)\end{array}$ \\
\hline Bad health & $\begin{array}{c}0.402 * * \\
(0.141)\end{array}$ & $\begin{array}{c}-0.101^{* *} \\
(0.046)\end{array}$ & $\begin{array}{c}-0.330^{*} \\
(0.162)\end{array}$ & $\begin{array}{c}-0.383^{* * *} \\
(0.117)\end{array}$ & $\begin{array}{c}0.289 * * \\
(0.120)\end{array}$ \\
\hline Poor health & $\begin{array}{l}0.153^{*} \\
(0.081)\end{array}$ & $\begin{array}{l}-0.052 \\
(0.052)\end{array}$ & $\begin{array}{c}0.008 \\
(0.145)\end{array}$ & $\begin{array}{c}-0.386^{* * *} \\
(0.104)\end{array}$ & $\begin{array}{c}0.157 \\
(0.093)\end{array}$ \\
\hline Good health & $\begin{array}{l}-0.083 * \\
(0.043)\end{array}$ & $\begin{array}{l}-0.006 \\
(0.040)\end{array}$ & $\begin{array}{c}-0.874 * * * \\
(0.255)\end{array}$ & $\begin{array}{c}0.079 \\
(0.092)\end{array}$ & $\begin{array}{c}0.739 * * * \\
(0.185)\end{array}$ \\
\hline Very good health & $\begin{array}{c}0.250 \\
(0.721)\end{array}$ & $\begin{array}{c}-0.208 * * * \\
(0.051)\end{array}$ & $\begin{array}{l}-0.701 \\
(0.768)\end{array}$ & $\begin{array}{c}2.951 * * * \\
(0.311)\end{array}$ & $\begin{array}{c}-2.186 * * * \\
(0.565)\end{array}$ \\
\hline Hhld income 1201-2000 € & $\begin{array}{c}0.005 \\
(0.079)\end{array}$ & $\begin{array}{c}0.045^{* * *} \\
(0.013)\end{array}$ & $\begin{array}{c}-0.116^{* * *} \\
(0.046)\end{array}$ & $\begin{array}{l}-0.043 \\
(0.089)\end{array}$ & $\begin{array}{c}0.066 \\
(0.057)\end{array}$ \\
\hline Hhld income 2001-3000 € & $\begin{array}{c}-0.223 \\
(0.191)\end{array}$ & $\begin{array}{c}-0.092 * * \\
(0.037)\end{array}$ & $\begin{array}{l}-0.032 \\
(0.274)\end{array}$ & $\begin{array}{c}0.294 \\
(0.225)\end{array}$ & $\begin{array}{c}0.045 \\
(0.265)\end{array}$ \\
\hline Hhld income $>3000 €$ & $\begin{array}{l}-0.559 \\
(0.368)\end{array}$ & $\begin{array}{c}0.009 \\
(0.071)\end{array}$ & $\begin{array}{l}-0.233 \\
(0.925)\end{array}$ & $\begin{array}{l}1.596 * * \\
(0.746)\end{array}$ & $\begin{array}{l}-0.828 \\
(0.671)\end{array}$ \\
\hline Consumer price index & $\begin{array}{c}-0.035 \\
(0.031)\end{array}$ & $\begin{array}{c}0.003 \\
(0.008)\end{array}$ & $\begin{array}{l}0.072 * \\
(0.038)\end{array}$ & $\begin{array}{c}0.070^{* *} \\
(0.031)\end{array}$ & $\begin{array}{c}-0.080 * * * \\
(0.017)\end{array}$ \\
\hline Gross domestic product & $\begin{array}{c}0.016 * * \\
(0.007)\end{array}$ & $\begin{array}{c}0.001 \\
(0.005)\end{array}$ & $\begin{array}{l}-0.025 \\
(0.015)\end{array}$ & $\begin{array}{c}-0.031 * * * \\
(0.008)\end{array}$ & $\begin{array}{c}0.044^{* *} \\
(0.017)\end{array}$ \\
\hline Activity rate of the region & $\begin{array}{c}0.010 \\
(0.046)\end{array}$ & $\begin{array}{l}0.033^{*} \\
(0.017)\end{array}$ & $\begin{array}{c}0.023 \\
(0.048)\end{array}$ & $\begin{array}{l}-0.065 \\
(0.050)\end{array}$ & $\begin{array}{l}-0.041 \\
(0.029)\end{array}$ \\
\hline Income per capita & $\begin{array}{l}-0.001 \\
(0.007)\end{array}$ & $\begin{array}{c}0.000 \\
(0.003)\end{array}$ & $\begin{array}{c}0.017 \\
(0.010)\end{array}$ & $\begin{array}{c}0.014 \\
(0.012)\end{array}$ & $\begin{array}{c}-0.035 * * * \\
(0.011)\end{array}$ \\
\hline Divorce rates & $\begin{array}{l}-0.077 \\
(0.098)\end{array}$ & $\begin{array}{l}-0.126^{*} \\
(0.062)\end{array}$ & $\begin{array}{c}-0.101 \\
(0.145)\end{array}$ & $\begin{array}{l}-0.076 \\
(0.161)\end{array}$ & $\begin{array}{l}0.400^{*} \\
(0.198)\end{array}$ \\
\hline$\%$ people in region with very poor health & $\begin{array}{c}-0.032 \\
(0.024)\end{array}$ & $\begin{array}{c}0.007 \\
(0.013)\end{array}$ & $\begin{array}{l}-0.041 \\
(0.053)\end{array}$ & $\begin{array}{c}0.000 \\
(0.057)\end{array}$ & $\begin{array}{c}0.102 \\
(0.064)\end{array}$ \\
\hline$\%$ people in region with poor health & $\begin{array}{l}-0.037 \\
(0.024)\end{array}$ & $\begin{array}{c}0.012 \\
(0.014)\end{array}$ & $\begin{array}{l}-0.016 \\
(0.055)\end{array}$ & $\begin{array}{l}-0.018 \\
(0.062)\end{array}$ & $\begin{array}{c}0.087 \\
(0.063)\end{array}$ \\
\hline$\%$ people in region with good health & $\begin{array}{l}-0.061 \\
(0.040)\end{array}$ & $\begin{array}{c}0.023 \\
(0.019)\end{array}$ & $\begin{array}{c}0.058 \\
(0.094)\end{array}$ & $\begin{array}{c}-0.021 \\
(0.095)\end{array}$ & $\begin{array}{c}0.030 \\
(0.097)\end{array}$ \\
\hline Share of public jobs relative to private & $\begin{array}{c}0.027 \\
(0.023)\end{array}$ & $\begin{array}{c}0.006 \\
(0.006)\end{array}$ & $\begin{array}{l}-0.017 \\
(0.017)\end{array}$ & $\begin{array}{c}-0.062 * * * \\
(0.018)\end{array}$ & $\begin{array}{c}0.017 \\
(0.021)\end{array}$ \\
\hline Industrial production index & $\begin{array}{l}-0.017 \\
(0.020)\end{array}$ & $\begin{array}{l}-0.002 \\
(0.003)\end{array}$ & $\begin{array}{c}0.017 \\
(0.014)\end{array}$ & $\begin{array}{c}0.016 \\
(0.019)\end{array}$ & $\begin{array}{l}-0.008 \\
(0.018)\end{array}$ \\
\hline Industrial price index & $\begin{array}{c}0.021^{* * *} \\
(0.006)\end{array}$ & $\begin{array}{c}-0.013^{* * *} \\
(0.004)\end{array}$ & $\begin{array}{c}-0.069 * * * \\
(0.014)\end{array}$ & $\begin{array}{l}-0.013 \\
(0.012)\end{array}$ & $\begin{array}{c}0.077 * * * \\
(0.013)\end{array}$ \\
\hline Constant & $\begin{array}{c}6.663 \\
(4.277)\end{array}$ & $\begin{array}{l}-1.130 \\
(1.407)\end{array}$ & $\begin{array}{l}-4.212 \\
(5.053)\end{array}$ & $\begin{array}{l}11.281^{*} \\
(5.425)\end{array}$ & $\begin{array}{c}8.385 \\
(6.672)\end{array}$ \\
\hline $\begin{array}{l}\text { N Observations } \\
\text { Pseudo R-squared }\end{array}$ & $\begin{array}{l}2,238 \\
0.107\end{array}$ & $\begin{array}{l}2,238 \\
0.044\end{array}$ & $\begin{array}{l}2,238 \\
0.354\end{array}$ & $\begin{array}{l}2,238 \\
0.139\end{array}$ & $\begin{array}{l}2,238 \\
0.168\end{array}$ \\
\hline
\end{tabular}

Notes: Robust standard errors in parentheses. Sample consists of respondents aged 21-65 who are unemployed, from the Spanish Time Use Survey (STUS) 2002-2003 and 2009-2010. Regional Unemployment Rates comes from the Spanish Statistical Office (Instituto Nacional de Estadística), defined at the level of the 17 autonomous regions in Spain (Ceuta and Melilla are excluded from the analysis). Definitions of time use variables can be found in Appendix Table B1. Time use variables are measured in hours per day. Partner working is a dummy variable that takes value " 1 " if respondent's partner works (part- or full-time), and value " 0 " otherwise. $*$ Significant at the $90 \%$ level **Significant at the $95 \%$ level ***Significant at the $99 \%$ level. 